\title{
Electronic Structure of Atomically Dispersed Supported Iridium Catalyst Controls Iridium Aggregation
}

\author{
Samira F. Kurtoğlu,,,,$+ \ddagger$ Adam S. Hoffman,\#, Deniz Akgül,,$\perp$ Melike Babucci, „ Viktorya \\ Aviyente, ${ }^{\perp}$ Bruce C. Gates, $"$ Simon R. Bare,$^{\S}$ and Alper Uzun ${ }^{*,+,+, \top}$
}

\begin{abstract}
tDepartment of Chemical and Biological Engineering, Koç University, Rumelifeneri Yolu, Sariyer, 34450, Istanbul, Turkey

‡Koç University TÜPRAŞ Energy Center (KUTEM), Koç University, Rumelifeneri Yolu, Sariyer, 34450, Istanbul, Turkey

§SSRL, SLAC National Accelerator Laboratory, Menlo Park, CA 94025, United States

\lrcorner Department of Chemistry, Bogazici University, Bebek, 34342, Istanbul, Turkey

"Department of Chemical Engineering, University of California, Davis, CA 95616, United States

TKoç University Surface Science and Technology Center (KUYTAM), Koç University, Rumelifeneri Yolu, Sariyer, 34450, Istanbul, Turkey

\#These authors contributed equally
\end{abstract}

*Corresponding author: auzun@ku.edu.tr 


\section{S1. Experimental and computational methods}

\section{S1.1. Materials and Methods}

$\left[\operatorname{lrCl}\left(\mathrm{C}_{8} \mathrm{H}_{14}\right)_{2}\right]_{2}$ (Sigma-Aldrich) was used to prepare $\operatorname{Ir}\left(\mathrm{C}_{2} \mathrm{H}_{4}\right)_{2}(\mathrm{acac})$ (acac = acetylacetonato) as described previously. ${ }^{1} \operatorname{Ir}(\mathrm{CO})_{2}$ (acac) (Strem), ionic liquid (IL, 1-ethyl-3methyl-imidazolium acetate ([EMIM][OAc])), $\mathrm{MgO}, \gamma-\mathrm{Al}_{2} \mathrm{O}_{3}, \mathrm{SiO}_{2}$ (Sigma-Aldrich) were purchased with the highest available purities. The IL was dried at $80^{\circ} \mathrm{C}$ for $6 \mathrm{~h}$ and kept under vacuum overnight before transferring to a Labconco glovebox filled with argon. Each metal oxide support was calcined under flowing $\mathrm{O}_{2}$ reaching the following temperatures at a ramp rate of $3{ }^{\circ} \mathrm{C} / \mathrm{min}$ : $700{ }^{\circ} \mathrm{C}$ for $\mathrm{MgO}, 500{ }^{\circ} \mathrm{C}$ for $\gamma-\mathrm{Al}_{2} \mathrm{O}_{3}$, and $520{ }^{\circ} \mathrm{C}$ for $\mathrm{SiO}_{2}$. Each support was held at these temperatures constant for $5 \mathrm{~h}$ under flowing $\mathrm{O}_{2}$ and subsequently they were left under vacuum overnight before transferring them to the argon-filled glove box. Atomically dispersed supported iridium complexes were prepared by the reaction of $18 \mathrm{mg}$ precursor $\left(\operatorname{Ir}\left(\mathrm{C}_{2} \mathrm{H}_{4}\right)_{2}(\mathrm{acac})\right.$ or $\left.\operatorname{Ir}(\mathrm{CO})_{2}(\mathrm{acac})\right)$ with $982 \mathrm{mg}$ support $\left(\mathrm{MgO}, \gamma-\mathrm{Al}_{2} \mathrm{O}_{3}\right.$, or $\left.\mathrm{SiO}_{2}\right)$ in $n$-pentane. The $n$-pentane was purified in an SBS-MBraun solvent purifier. This slurry was mixed for $24 \mathrm{~h}$ and the solvent was removed by overnight-evacuation. The resultant catalyst with an iridium loading of approximately $1 \mathrm{wt} \%$ was stored in an argon-filled glove box. To prepare IL-coated iridium complex, $100 \mathrm{mg}$ supported iridium complex $\left(\operatorname{Ir}\left(\mathrm{C}_{2} \mathrm{H}_{4}\right)_{2} / \mathrm{SiO}_{2}\right.$ or $\left.\operatorname{Ir}(\mathrm{CO})_{2} / \mathrm{SiO}_{2}\right)$ was physically mixed with $50 \mathrm{mg}$ IL ([EMIM][OAc]). Then, excess amount of $\mathrm{SiO}_{2}(100 \mathrm{mg})$ was added to this mixture to adsorb the excess unadsorbed IL. The resultant IL-coated samples had an Ir loading and an IL loading of approximately 0.4 and $20 \mathrm{wt} \%$, respectively. We stress that the IL loading was set such that only a few molecular layers of IL were present on the surface of each sample-so that there was sufficient ionic liquid to cover all of the metal complexes without any significant mass transfer limitation.

\section{S1.2. Infrared (IR) spectroscopy}

To measure the IR spectra of the samples and the precursors, a Bruker Vertex 80v spectrometer was used in transmission mode. The spectral resolution was $2 \mathrm{~cm}^{-1}$. In the glove box, the samples were prepared by pressing approximately $10 \mathrm{mg}$ of each between two $\mathrm{KBr}$ windows. Just before the measurements, these prepared samples were transferred to the sample chamber of the instrument without exposing them to air in sealed sample holders. The sample chamber was then evacuated quickly after the insertion of the sample to record the IR spectra of the samples with moisture and air exclusion at room temperature. Background scans and sample measurements were performed by averaging 256 scans.

\section{S1.3. X-ray absorption spectroscopy (XAS)}

\section{S1.3.1. Measurements}

Continuous-scan XAS measurements were performed at beam line 2-2 at the Stanford Synchrotron Radiation Lightsource (SSRL) equipped with a double-crystal, water-cooled, Si(220) monochromator. Spectra were collected in fluorescence detection mode using a passivated implanted planar silicon (PIPS) detector to measure the signal with nitrogen-filled ion chambers to record the fluorescence spectra. Approximately $50 \mathrm{mg}$ of a sample was loaded into an in-situ XAS cell ${ }^{2}$, in an argon-filled glove box and handled in the absence of air at the beam line to prevent contamination. A bimetallic Ir/Pt foil (20 wt\% Ir, $80 \mathrm{wt} \% \mathrm{Pt}$ ) (EXAFS Materials) was scanned simultaneously with the sample for energy calibration. Continuousscan XA spectra were measured from $200 \mathrm{eV}$ below the Ir $L_{\text {III }}$ edge $(11215 \mathrm{eV})$ to $k=14.95$ $\AA^{-1}$ (where $k$ is the wave vector) in $156 \mathrm{~s}$. As-prepared samples were measured under flowing helium at room temperature. The sample in flowing $\mathrm{H}_{2}$ was then heated to $120^{\circ} \mathrm{C}$ at a ramp rate of $3{ }^{\circ} \mathrm{C} / \mathrm{min}$ to collect the spectra during the temperature programmed reduction (TPR). As the sample temperature reached $120^{\circ} \mathrm{C}$ the gas flow was changed to helium and the cell 
was immediately cooled to room temperature. During the experiment, the continuous-scan XA spectra were collected continuously. At least seven scans were collected and averaged at room temperature in flowing He to characterize the post-TPR state.

\section{S1.3.2. Data Analysis}

Analysis of the XAS data was carried out with the software ATHENA and ARTEMIS parts of Demeter ${ }^{3}$ package and the software XDAP;4 details are given elsewhere. ${ }^{5-6}$ Data alignment, edge calibration, deglitching, and rebinning (needed for fitting data with XDAP) were performed with ATHENA. The absorption edge of the reference channel representing the spectrum of iridium metal was determined as the maximum of the first derivative of the normalized absorbance with respect to beam energy, and used to calibrate each edge energy of the reference channel in each scan to the reported Ir LIII energy, $11215.0 \mathrm{eV}$.

ARTEMIS and XDAP were used to fit the extended X-ray absorption fine structure (EXAFS) data. Models were chosen to include all plausible absorber-scatterer combinations suggested by the synthesis chemistry and IR spectra of the samples, as well as the chemistry of related samples. ${ }^{5-6}$ Various models with various numbers of scattering-paths were considered in the data fitting. ARTEMIS was mostly used to develop fit models for the asprepared samples as it allows simultaneous fitting of similar spectra. ATHENA was used for normalization, background subtraction, and conversion of the data into a chi file prior to fitting the data in ARTEMIS. Absorber-scatterer paths were simulated using FEFF6.07 imbedded in the ARTEMIS software based upon cif files of known compounds. ${ }^{1}$ The Ir-Ir scattering path was obtained from Ir metal (Materials Project: $\mathrm{mp}-101$ ) and the $\mathrm{Ir}-\mathrm{O}$ and $\mathrm{Ir}-\mathrm{C}$ scattering paths from $\operatorname{Ir}\left(\mathrm{C}_{2} \mathrm{H}_{4}\right)_{2}(\mathrm{acac})$. The $\mathrm{S}_{0}{ }^{2}$ term was determined to be 0.75 on the basis of fitting the IrPt foil with a single Ir-Ir scattering path, assuming bulk coordination. This value was used in the EXAFS modeling using ARTEMIS.

EXAFS spectra of a representative as-prepared sample, the $\gamma-\mathrm{Al}_{2} \mathrm{O}_{3}$-supported iridium complex, and those of the uncoated samples following the temperature ramp to $120^{\circ} \mathrm{C}$ in flowing $\mathrm{H}_{2}$, presenting an apparent $\mathrm{Ir}-\mathrm{Ir}$ contribution in their corresponding Fourier-transformed EXAFS data, were fitted using XDAP, which allows the efficient application of a difference-file technique ${ }^{8-11}$ for the determination of the optimized fit parameters and isolation of individual shells. Reference files used in the XDAP fitting, with backscattering amplitudes and phase shifts for Ir-Ir, Ir-O, Ir-C, and Ir-Al contributions were calculated with the software FEFF7. ${ }^{7}$ from crystallographic coordinates of the unit cells of the reference compounds iridium metal, $\operatorname{Ir}\left(\mathrm{C}_{2} \mathrm{H}_{4}\right)_{2}$ (acac), ${ }^{1}$ and IrAl alloy. ${ }^{12}$ Iterative fitting was carried out for various structural models until the best agreement was attained between the calculated $k^{0}-, k^{1}-, k^{2}$-, and $k^{3}$-weighted EXAFS data and the postulated model. The fit model obtained by using XDAP on the asprepared $\gamma-\mathrm{Al}_{2} \mathrm{O}_{3}$-supported iridium complex was also compared with that obtained by using ARTEMIS to check whether the data is consistently characterized with any Ir-Ir coordination shell or not.

The fitting ranges in both $k$ - and $R$-space, where $R$ is the distance from the absorbing Ir atom, in the analysis of the data were determined by the data quality; the range in $k$ was in general between $3.2 \pm 0.3$ and $13.0 \pm 2.0 \AA^{-1}$, and the range in $R$ was generally 1.0-2.3 $\AA$ for atomically dispersed $\gamma-\mathrm{Al}_{2} \mathrm{O}_{3}$-supported $\operatorname{Ir}\left(\mathrm{C}_{2} \mathrm{H}_{4}\right)_{2}$ complex, and it was 1.0-3.2 $\AA$ for samples forming clusters. These values were used with the Nyquist theorem to estimate the justified number of fitting parameters. ${ }^{13}$ The accuracies of the parameters obtained by XDAP fitting are estimated to be as follows: coordination number $N, \pm 20 \%$ for Ir-low-Z scatterer contributions, $\pm 10 \%$ for Ir-high-Z scatterer contributions; distance $R, \pm 0.02 \AA$; disorder term $\Delta \sigma^{2}, \pm 20 \%$; and inner potential correction $\Delta E_{0}, \pm 20 .{ }^{13}$

The goodness of fit value for the fits obtained using XDAP were calculated as follows: 


$$
\text { goodness of fit }=\frac{v}{N P T S\left(v-N_{\text {free }}\right)} \sum_{i=1}^{N P T S}\left(\frac{\chi_{\text {exp }, i}-\chi_{\bmod e l, i}}{\sigma_{\text {exp }, i}}\right)^{2}
$$

where $\chi_{\text {model }}$ and $\chi_{\text {exp }}$ are the fit and experimental EXAFS respectively, $\sigma_{\text {exp }}$ is the error in the experimental results, $v$ is the number of independent data points in the fit range, and NPTS is the actual number of data points in the fit range.

We emphasize that the central conclusions of this study are based on whether an Ir-Ir contribution is present or not, and, if present, on the differences in the corresponding Ir-Ir coordination numbers in the fit models characterizing the post-TPR samples. Consistency of the results in indicating the lack or presence of an Ir-Ir contribution (with consistent coordination numbers, if an Ir-Ir contribution is present) in the fit models obtained by using $X D A P$ and ARTEMIS on the same data set confirms the central conclusions of this work.

\section{S1.4. Density functional theory (DFT) calculations}

Geometry optimization was performed using DFT ${ }^{14}$ by Perdew-Burke-Ernzerhof $(\mathrm{PBE})^{15}$ functional with the 6-31G(d,p) basis set for $\mathrm{H}, \mathrm{C}, \mathrm{O}, \mathrm{Mg}, \mathrm{Al}$, and $\mathrm{Si}$ atoms and the Los Alamos National Laboratory (LANL2DZ) basis set developed by Hay and Wadt for Ir atoms. ${ }^{16}$ PBE functional has been used for predicting structures and energetics of the transition metal complexes. ${ }^{17}$ All calculations have been carried out with the Gaussian 09 series of programs. ${ }^{18}$ Charge distributions were calculated by using the CM5 and the Hirshfeld charge analysis. ${ }^{19}$ The ideal gas approximation ( $298 \mathrm{~K}$ and $1 \mathrm{~atm}$ ) has been used in the calculations.

Early experimental and computational studies have claimed that the accurate morphology of metal cluster and the interaction of the metal and the support have importance for clarifying the effects of metal oxide supports on chemical event. DFT calculations can provide an alternative way to understand the structure of metal-oxide supports. However, metal clusters modeled with DFT studies may be smaller than those used experimentally in order to have reasonable computational times. ${ }^{20}$ Therefore, for reducing the computational cost, we have modeled the metal oxide supports by reducing their sizes. The $\mathrm{SiO}_{2^{-}}, \gamma-\mathrm{Al}_{2} \mathrm{O}_{3^{-}}$, and $\mathrm{MgO}-$ supported $\operatorname{Ir}(\mathrm{CO})_{2}$ and $\operatorname{Ir}\left(\mathrm{C}_{2} \mathrm{H}_{4}\right)_{2}$ complexes were modeled as follows. The $\mathrm{SiO}_{2}$-supported $\operatorname{Ir}(\mathrm{CO})_{2}$ and $\operatorname{Ir}\left(\mathrm{C}_{2} \mathrm{H}_{4}\right)_{2}$ complexes were simulated by using a tetrahedral arrangement with one silicon bonded to four oxygen atoms. Vummaleti and co-workers reported the same pattern for silicon and oxygen atoms by considering a zeolite support. ${ }^{21}$ Biswas and coworkers used $\left(\mathrm{Al}_{2} \mathrm{O}_{3}\right)_{n}$ clusters for $\mathrm{n}=3,4$, and 6 to have a valid model for $\gamma-\mathrm{Al}_{2} \mathrm{O}_{3}$ with a (110) pattern for the $\mathrm{Al}_{2} \mathrm{O}_{3}$ surface, whereby they reported the thermodynamic stability of the bulk structure of $\gamma-\mathrm{Al}_{2} \mathrm{O}_{3}{ }^{22}$ Thus, the (100) surface of the $\mathrm{Al}_{12} \mathrm{O}_{18}$ cluster reported by Biswas et al. was used to simulate the $\gamma-\mathrm{Al}_{2} \mathrm{O}_{3}$-supported $\operatorname{Ir}(\mathrm{CO})_{2}$ and $\operatorname{Ir}\left(\mathrm{C}_{2} \mathrm{H}_{4}\right)_{2}$ complexes. ${ }^{22}$ For $\mathrm{MgO}$, the (100) crystal was used as reported in our previous work. ${ }^{23}$ In addition, the IR carbonyl stretching frequencies of the supported $\operatorname{Ir}(\mathrm{CO})_{2}$ complexes have been calculated by taking into account scaling factor as $0.986 .{ }^{24}$

\section{S2. Additional Structural Characterization Data}

\section{S2.1. IR spectra of representative as-prepared supported iridium complex samples, MgO-supported $\operatorname{Ir}\left(\mathrm{C}_{2} \mathrm{H}_{4}\right)_{2}$ and $\operatorname{Ir}(\mathrm{CO})_{2}$ complexes}

Figure S1 shows the IR spectra of $\mathrm{MgO}$ (calcined at $700{ }^{\circ} \mathrm{C}$ ), the precursor $\left(\operatorname{Ir}\left(\mathrm{C}_{2} \mathrm{H}_{4}\right)_{2}(\mathrm{acac})\right)$, and the resulting sample obtained by the reaction of $\operatorname{Ir}\left(\mathrm{C}_{2} \mathrm{H}_{4}\right)_{2}(\mathrm{acac})$ with $\mathrm{MgO}$. Figure $\mathrm{S} 1 \mathrm{a}$ represents the $\mathrm{C}-\mathrm{H}$ stretching region. The bands characterizing the $\pi-$ bonded ethylene ligands of the precursor are at 3046 and $2978 \mathrm{~cm}^{-1}$, matching those of previously prepared precursors $\left(3045\right.$ and $\left.2981 \mathrm{~cm}^{-1}\right) .{ }^{1,5}$ The supported complex formed by the reaction of $\mathrm{MgO}$ with $\operatorname{Ir}\left(\mathrm{C}_{2} \mathrm{H}_{4}\right)_{2}$ (acac) is characterized by IR bands at 3080 and $3001 \mathrm{~cm}^{-1}$, which are assigned to $\pi$-bonded ethylene ligands in the samples showing similarities with other, previously reported complexes. ${ }^{5,25}$ According to Figure S1b, the IR spectrum of the 
$\operatorname{Ir}\left(\mathrm{C}_{2} \mathrm{H}_{4}\right)_{2}$ (acac) precursor is characterized by bands at $1613,1578,1525,1466,1417,1390$, 1360 , and $1275 \mathrm{~cm}^{-1}$ corresponding to the acac ligands. The acac region of the sample prepared by the reaction of $\mathrm{MgO}$ with $\operatorname{Ir}\left(\mathrm{C}_{2} \mathrm{H}_{4}\right)_{2}$ (acac) is characterized by the bands at 1609 , $1583,1519,1458,1406,1364$, and $1263 \mathrm{~cm}^{-1}$, indicating that the (acac) related features are slightly different on the supported samples. Furthermore, the bands of the as-prepared sample are consistent with those of a previously reported similar sample $(1622,1521,1467,1413$, 1365 , and $1261 \mathrm{~cm}^{-1}$ ) prepared by the reaction of the same support and same precursor. ${ }^{25}$ Consistently, these data show that the acac ligand of the precursor was dissociated and became chemisorbed on the support possibly forming $\mathrm{Mg}(\mathrm{acac})$ or $\mathrm{H}(\mathrm{acac})$ species. ${ }^{25-27}$
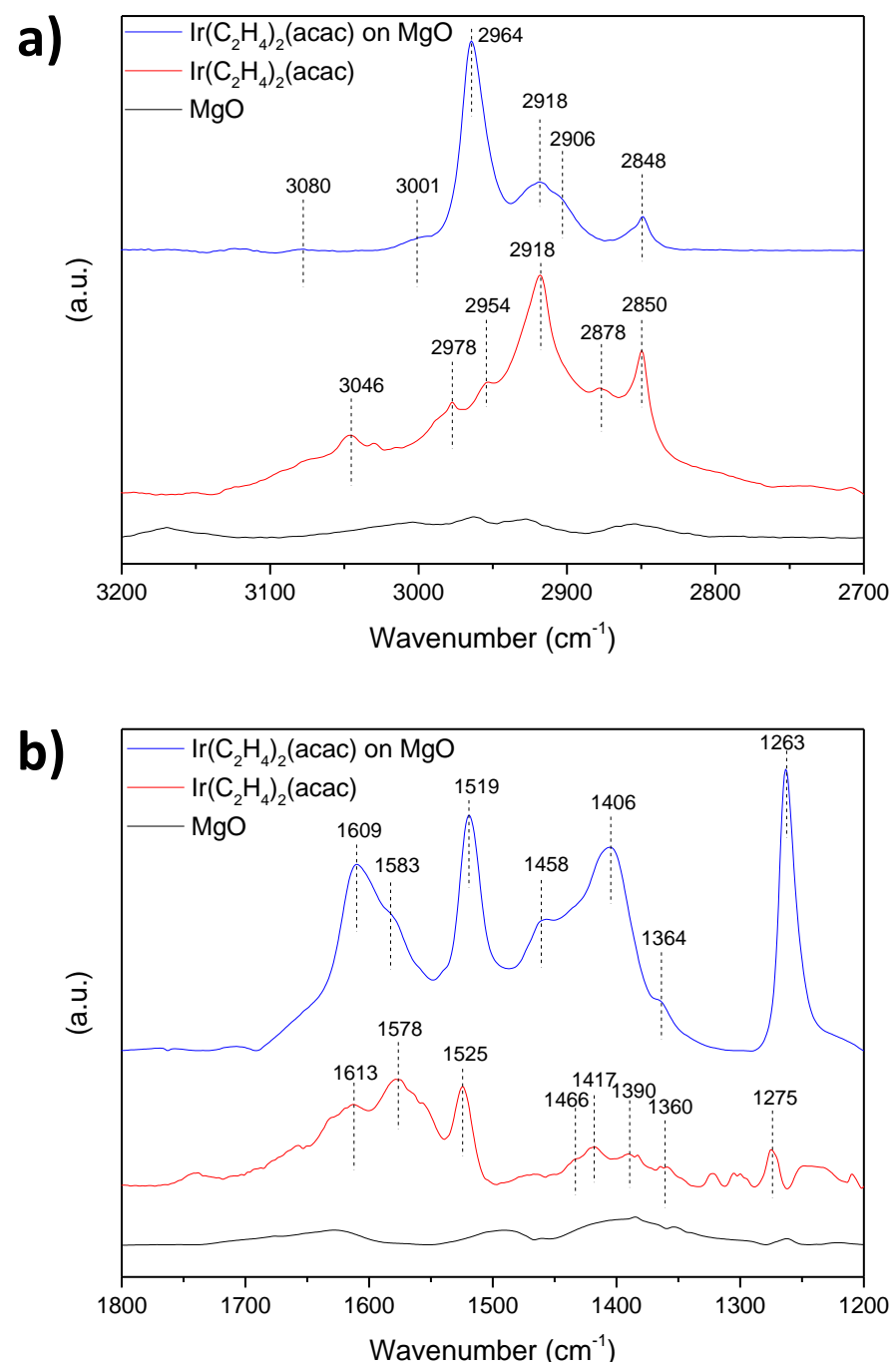

Figure S1. IR spectra characterizing the as-prepared catalyst formed by the reaction of $\mathrm{MgO}$ (calcined at $700{ }^{\circ} \mathrm{C}$ ) with $\operatorname{Ir}\left(\mathrm{C}_{2} \mathrm{H}_{4}\right)_{2}(\mathrm{acac})$ in $n$-pentane after removal of the solvent: a) in the region of $3200-2700 \mathrm{~cm}^{-1}$ and $\mathrm{b}$ ) in the region of $1800-1200 \mathrm{~cm}^{-1}$.

Figure S2 shows the IR spectra of the support ( $\mathrm{MgO}$, calcined at $\left.700{ }^{\circ} \mathrm{C}\right)$, precursor $\left(\operatorname{Ir}(\mathrm{CO})_{2}(\mathrm{acac})\right)$, and the sample obtained by the reaction of $\mathrm{MgO}$ with $\operatorname{Ir}(\mathrm{CO})_{2}(\mathrm{acac})$. Figure $\mathrm{S} 2 \mathrm{a}$ shows that the $\mathrm{CO}$ ligands of the precursor are represented by the symmetric $\left(v(\mathrm{CO})_{\text {sym }}\right)$ and asymmetric $\left(v(C O)_{\text {asym }}\right)$ bands located at 2050 and $1987 \mathrm{~cm}^{-1}$, respectively. The sample resulting from the reaction of the precursor with the support is characterized by similar features in this $v(\mathrm{CO})$ region. The symmetric $\left(v(\mathrm{CO})_{\text {sym }}\right)$ and asymmetric $\left(v(\mathrm{CO})_{\text {asym }}\right)$ vibration frequencies are shifted in the $\operatorname{Ir}(\mathrm{CO})_{2} / \mathrm{MgO}$ sample compared to the precursor, indicating a 
different species formed on the supported complex. Observation of these two distinct bands in the $\mathrm{CO}$ stretching region and the absence of any bridging $\mathrm{CO}$ bands are consistent with the formation of iridium gem-dicarbonyl species and the absence of any iridium clusters, ${ }^{28}$ respectively. Figure $S 2 b$ illustrates the acac ligand region. The bands characterizing the sample obtained by the reaction of the precursor with the support shifted relative to the corresponding bands of the precursor. Furthermore, the bands characterizing the acac region of the supported complex $\left(1369,1405,1461,1521\right.$, and $\left.1610 \mathrm{~cm}^{-1}\right)$ resemble those of a previously prepared sample $\left(1365,1404,1460,1541\right.$, and $\left.1568 \mathrm{~cm}^{-1}\right) \cdot{ }^{29}$ Thus, it is inferred that acac ligands present on the precursor reacted with surface hydroxyl groups to form adsorbed species, consistent with previous reports. ${ }^{29,30}$
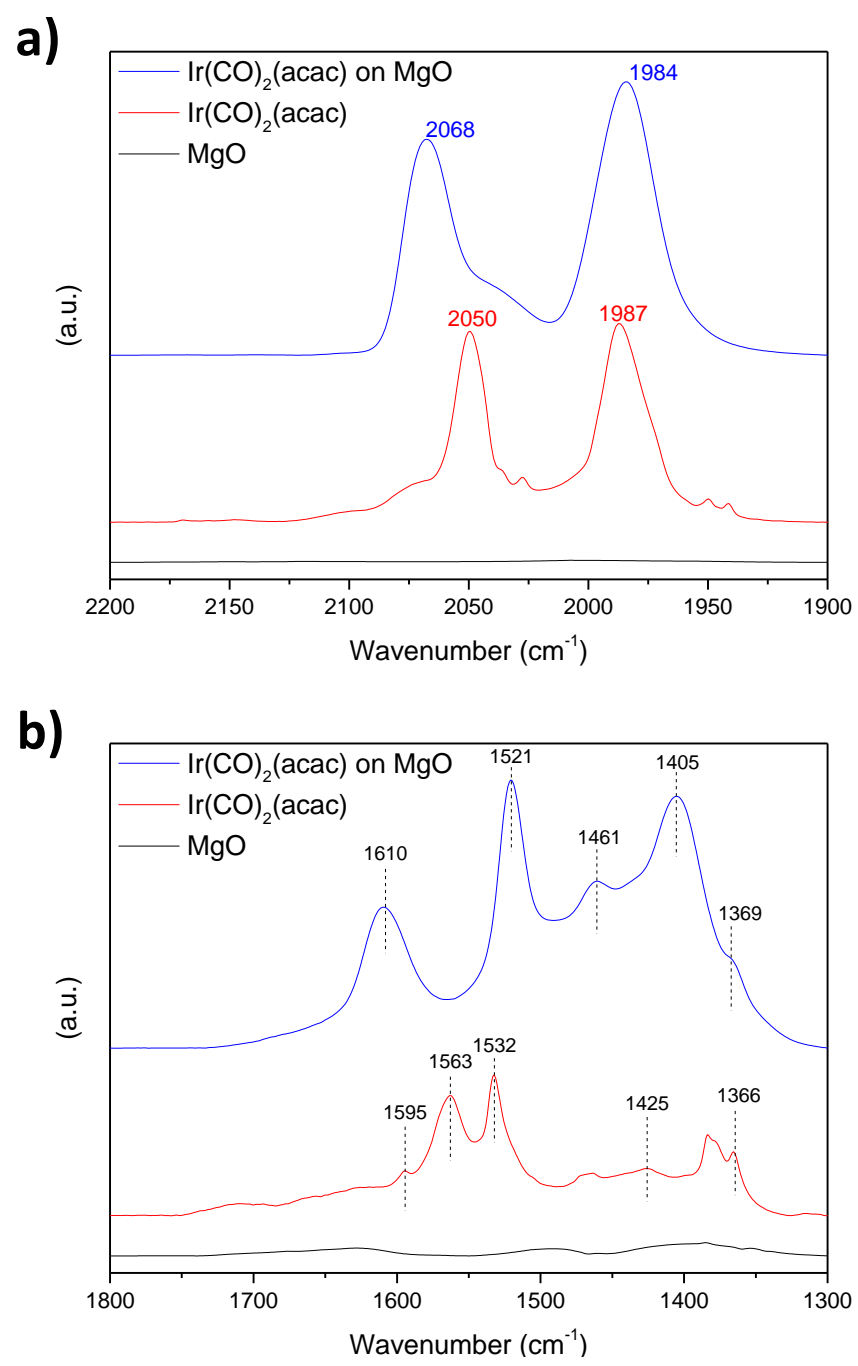

Figure S2. IR spectra characterizing the as-prepared catalyst formed by the reaction of $\mathrm{MgO}$ (calcined at $700{ }^{\circ} \mathrm{C}$ ) with $\operatorname{Ir}(\mathrm{CO})_{2}(\mathrm{acac})$ in $n$-pentane after removal of the solvent: a) in the region of $2200-1900 \mathrm{~cm}^{-1}$ and $b$ ) in the region of $1800-1300 \mathrm{~cm}^{-1}$.

\section{S2.2. EXAFS results characterizing as-prepared samples}

A comparison of the raw EXAFS data (Figure S3) and the Fourier-transformed EXAFS data (Figure S4) characterizing each sample shows that all samples are similar in their asprepared states. The best-fit EXAFS models, determined using ARTEMIS, characterizing the as-prepared samples are presented in Table S1 and Figure S5. Attempts to model each spectrum individually with two scattering paths (Ir-C and $\mathrm{Ir}-\mathrm{O}$ ), representing the ligand and 
support interaction with the metal center, resulted in fits that had varying coordination numbers and $\sigma^{2}$ values for similar paths. Simultaneous fitting was used to get the models to converge on one solution for both scattering paths. The cif file of $\operatorname{Ir}\left(\mathrm{C}_{2} \mathrm{H}_{4}\right)_{2}(\mathrm{acac}),{ }^{1}$ the precursor, was used to generate scattering paths. The best-fit model required two scattering paths, fitted as Ir-O and Ir-C single scattering paths, at bonding distances, 2.04-2.18 $\AA$, respectively. Chemical speciation ( $\mathrm{C}$ vs. $\mathrm{O}$ ) of these two scattering paths could not be uniquely identified because of the similar atomic numbers of $C$ and $O$. Consistent with reports, $,, 25,31$ the model converged to having one path with a higher coordination at a long $R(\approx 2.18 \AA)$ and a second path with a lower coordination at a short $R(\approx 2.03 \AA$ ) (Table S1). Although the fits here do not match the expected coordination numbers of 4 and 2, $C$ and $O$, respectively, the ARTEMIS model converged to a similar 2:1 ratio (Table S1). Additional models were tested to include an $\mathrm{Ir}-\mathrm{O}-\mathrm{Mg} / \mathrm{Al} / \mathrm{Si}$ single scattering interaction. The converged models resulted in poor fits including parameters that did not make chemical sense (coordination numbers or $\sigma^{2}$ values that were negative or large, $>20$ or 0.2 , respectively) with high errors in the overall fit. There appears to be a component to the overall EXAFS from scattering paths (single or multiple scattering) which results in a feature in the magnitude of the Fourier-transform at 2.5-4 $\mathrm{A}$. We were unsuccessful in performing a satisfactory fit that accounts for this feature.

However, as presented below (Figure S6 and Table S2), we were successful in obtaining satisfactory fits matching those previously reported for analogous $\operatorname{Ir}\left(\mathrm{C}_{2} \mathrm{H}_{4}\right)_{2}$ complexes supported on various metal oxides ${ }^{5-6,25}$ by using XDAP.

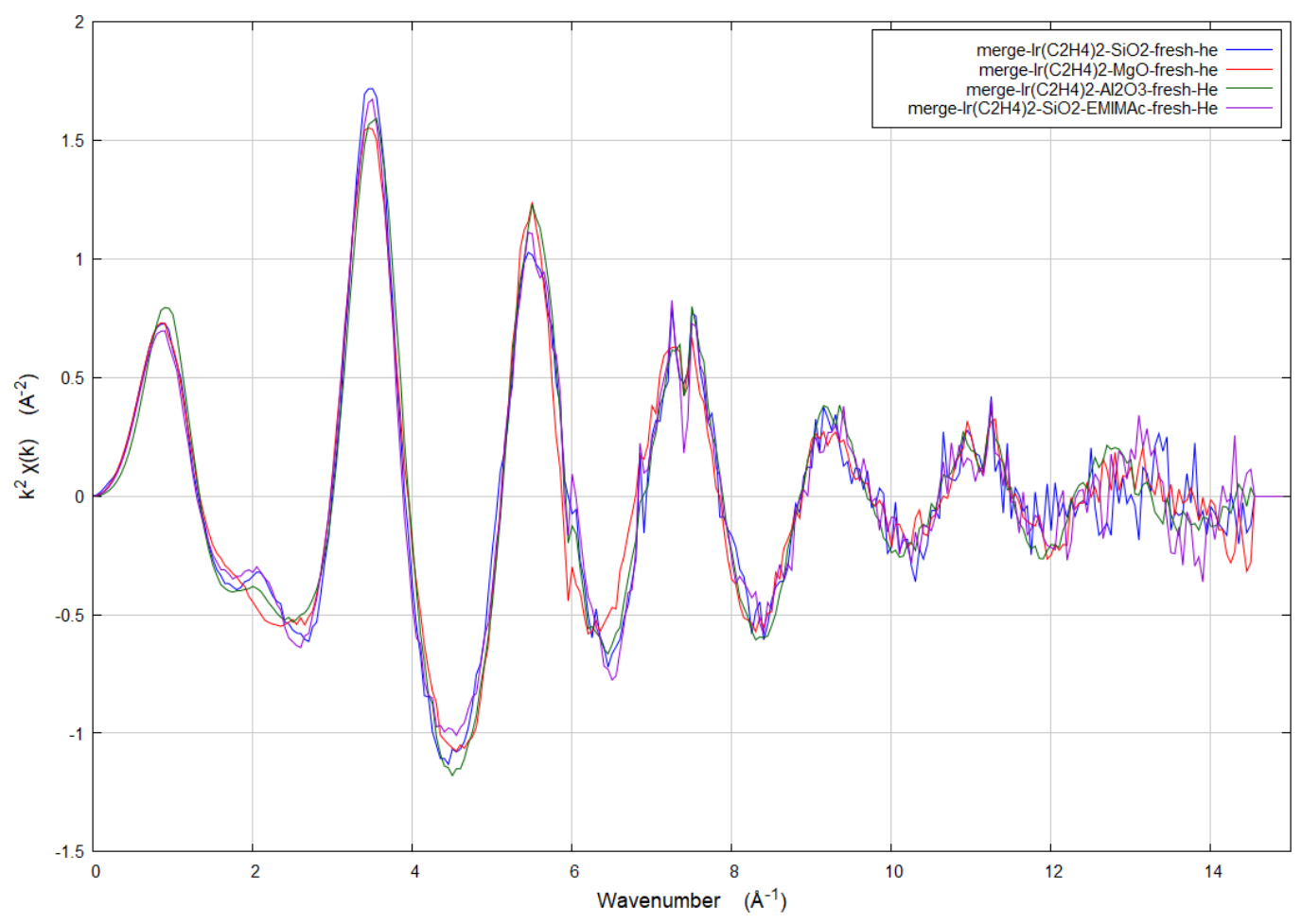

Figure S3. $k^{2}$-weighted EXAFS function, $\chi$, of all as-prepared samples collected at the Ir $\mathrm{L}_{111}$ edge: $\mathrm{SiO}_{2^{-}}$(blue), $\gamma-\mathrm{Al}_{2} \mathrm{O}_{3^{-}}$(green), $\mathrm{MgO}$-supported (red), and [EMIM][OAc]-coated $\mathrm{SiO}_{2^{-}}$ supported (purple) $\operatorname{Ir}\left(\mathrm{C}_{2} \mathrm{H}_{4}\right)_{2}$ complexes. 
a)

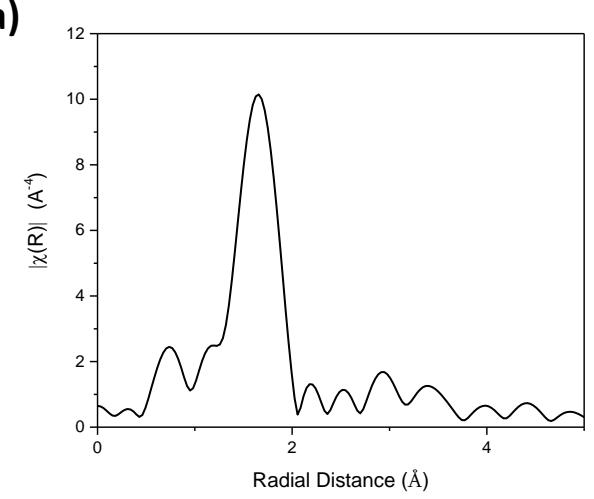

b)

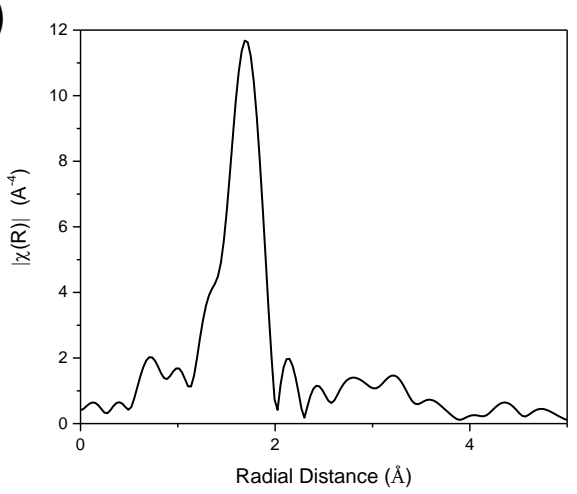

c)

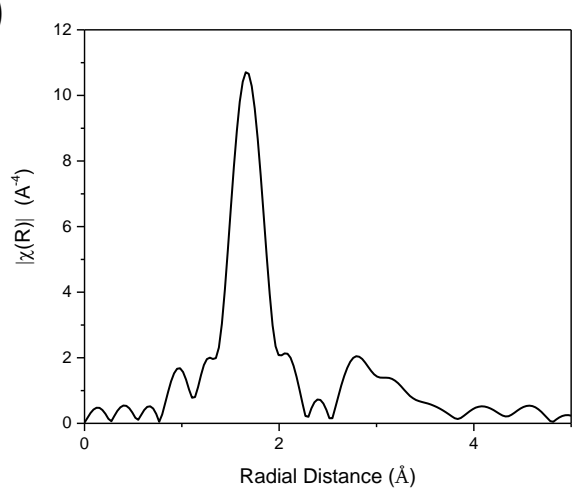

d)

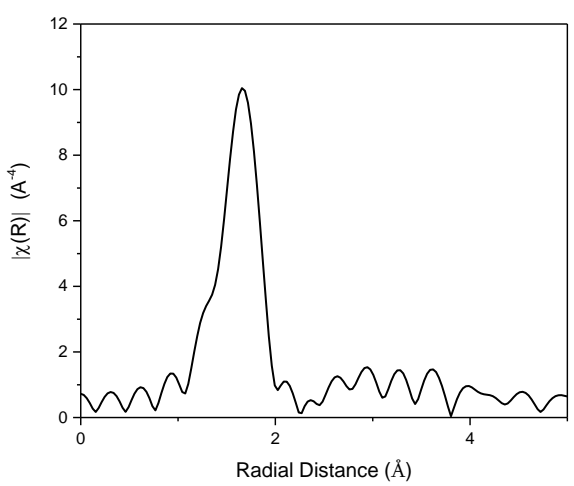

Figure S4. Magnitude of the Fourier-transform ( $k^{3}$-weighted) of EXAFS spectra comparing asprepared structures of a) $\mathrm{SiO}_{2^{-}}$, b) $\gamma-\mathrm{Al}_{2} \mathrm{O}_{3^{-}}$, c) $\mathrm{MgO}$-supported $\operatorname{Ir}\left(\mathrm{C}_{2} \mathrm{H}_{4}\right)_{2}$ complexes, and d) [EMIM][OAc]-coated $\mathrm{SiO}_{2}$-supported $\operatorname{Ir}\left(\mathrm{C}_{2} \mathrm{H}_{4}\right)_{2}$ complex. 
Table S1. Summary of the best-fit EXAFS models obtained by simultaneous fitting of the asprepared structures using ARTEMIS: $\mathrm{SiO}_{2^{-}}, \gamma-\mathrm{Al}_{2} \mathrm{O}_{3^{-}}, \mathrm{MgO}$-supported $\operatorname{Ir}\left(\mathrm{C}_{2} \mathrm{H}_{4}\right)_{2}$ complexes, and [EMIM][OAc]-coated $\mathrm{SiO}_{2}$-supported $\operatorname{Ir}\left(\mathrm{C}_{2} \mathrm{H}_{4}\right)_{2}$ complex. Data were collected with samples in flowing helium $(20 \mathrm{ml} / \mathrm{min})$ at room temperature prior to the start of the TPR treatment.

\begin{tabular}{|c|c|c|c|c|c|c|c|c|}
\hline Sample & $\begin{array}{c}\text { Absorber- } \\
\text { backscatterer } \\
\text { path }\end{array}$ & C.N. ${ }^{a}$ & $\begin{array}{c}10^{3} x \\
\sigma^{2 b} \\
\left(\AA^{2}\right)\end{array}$ & $\begin{array}{l}R^{c} \\
(\AA)\end{array}$ & $S_{0}^{2}$ & $\begin{array}{l}\Delta E_{0}{ }^{d} \\
(e V)\end{array}$ & $\begin{array}{c}\text { k-range } \\
\left(\AA^{-1}\right)\end{array}$ & $\begin{array}{c}R- \\
\text { range } \\
(\AA)\end{array}$ \\
\hline \multirow{2}{*}{$\operatorname{Ir}\left(\mathrm{C}_{2} \mathrm{H}_{4}\right)_{2} / \mathrm{SiO}_{2}$} & $\mathrm{Ir}-\mathrm{O}$ & $5.5(1.6)$ & $4.0(1.5)$ & $2.04(0.01)$ & & & & \\
\hline & $\mathrm{Ir}-\mathrm{C}$ & $3.5(2.0)$ & $7.3(3.6)$ & $2.18(0.04)$ & & & & \\
\hline \multirow[t]{2}{*}{$\operatorname{Ir}\left(\mathrm{C}_{2} \mathrm{H}_{4}\right)_{2} / \gamma-\mathrm{Al}_{2} \mathrm{O}_{3}$} & $\mathrm{Ir}-\mathrm{O}$ & $5.5(1.6)$ & $4.0(1.5)$ & $2.04(0.02)$ & & & & \\
\hline & $\mathrm{Ir}-\mathrm{C}$ & $3.5(2.0)$ & $7.3(3.6)$ & $2.13(0.05)$ & & & & \\
\hline \multirow[t]{2}{*}{$\operatorname{Ir}\left(\mathrm{C}_{2} \mathrm{H}_{4}\right)_{2} / \mathrm{MgO}$} & $\mathrm{Ir}-\mathrm{O}$ & $5.5(1.6)$ & $4.0(1.5)$ & $2.08(0.01)$ & 0.75 & $8.8(0.8)$ & $2.98-12.43$ & $1.0-2.3$ \\
\hline & $\mathrm{Ir}-\mathrm{C}$ & $3.5(2.0)$ & $7.3(3.6)$ & $2.18(0.03)$ & & & & \\
\hline $\begin{array}{l}\text { [EMIM][OAc]- } \\
\text { coated }\end{array}$ & $\mathrm{Ir}-\mathrm{O}$ & $5.5(1.6)$ & $4.0(1.5)$ & $2.03(0.01)$ & & & & \\
\hline $\operatorname{Ir}\left(\mathrm{C}_{2} \mathrm{H}_{4}\right)_{2} / \mathrm{SiO}_{2}$ & $\mathrm{Ir}-\mathrm{C}$ & $3.5(2.0)$ & $7.3(3.6)$ & $2.19(0.04)$ & & & & \\
\hline
\end{tabular}

${ }^{a}$ Coordination number, bdisorder in neighbor distance, cabsorber-backscatter distance, denergy shift. Numbers in parenthesis are the error. 

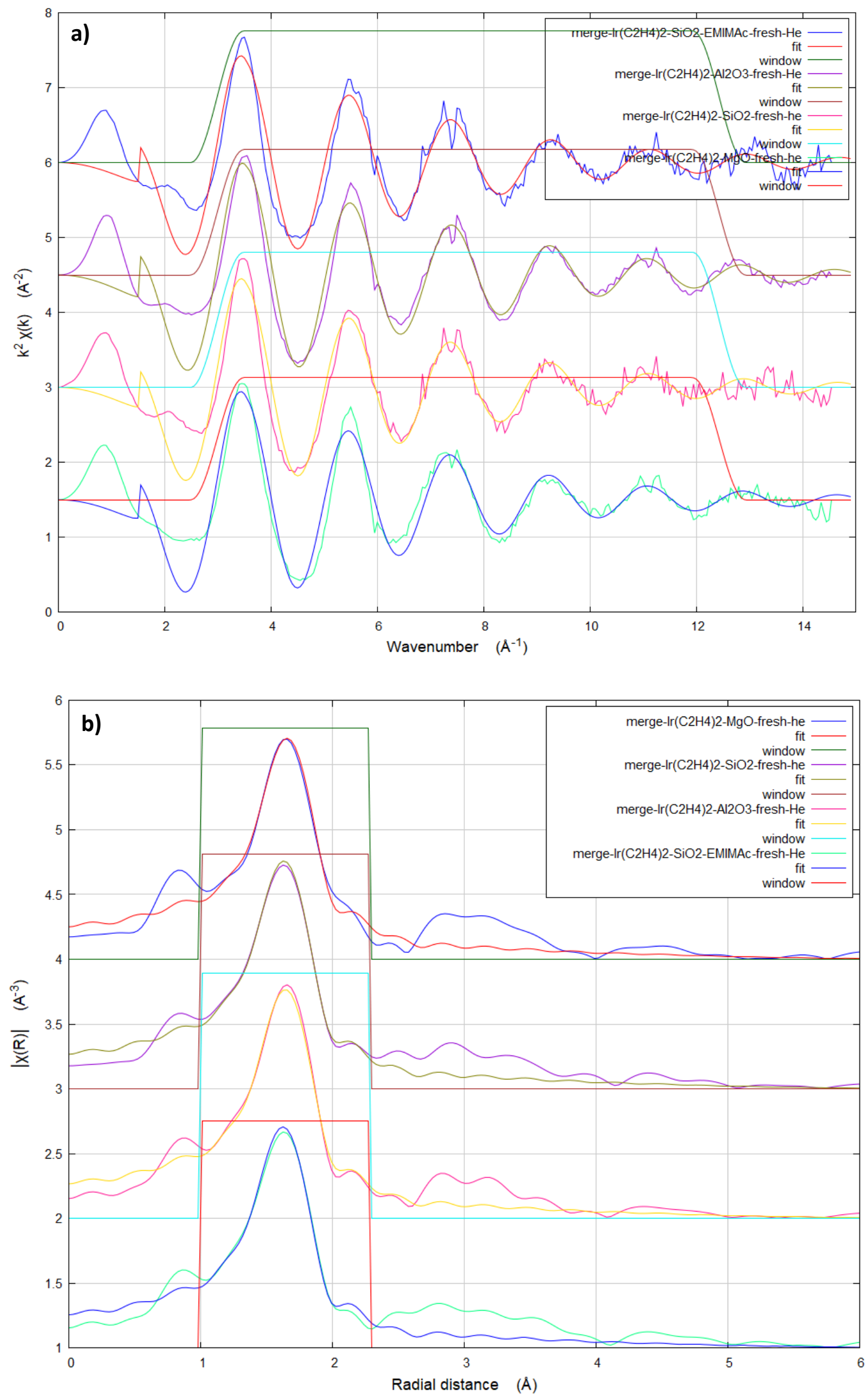


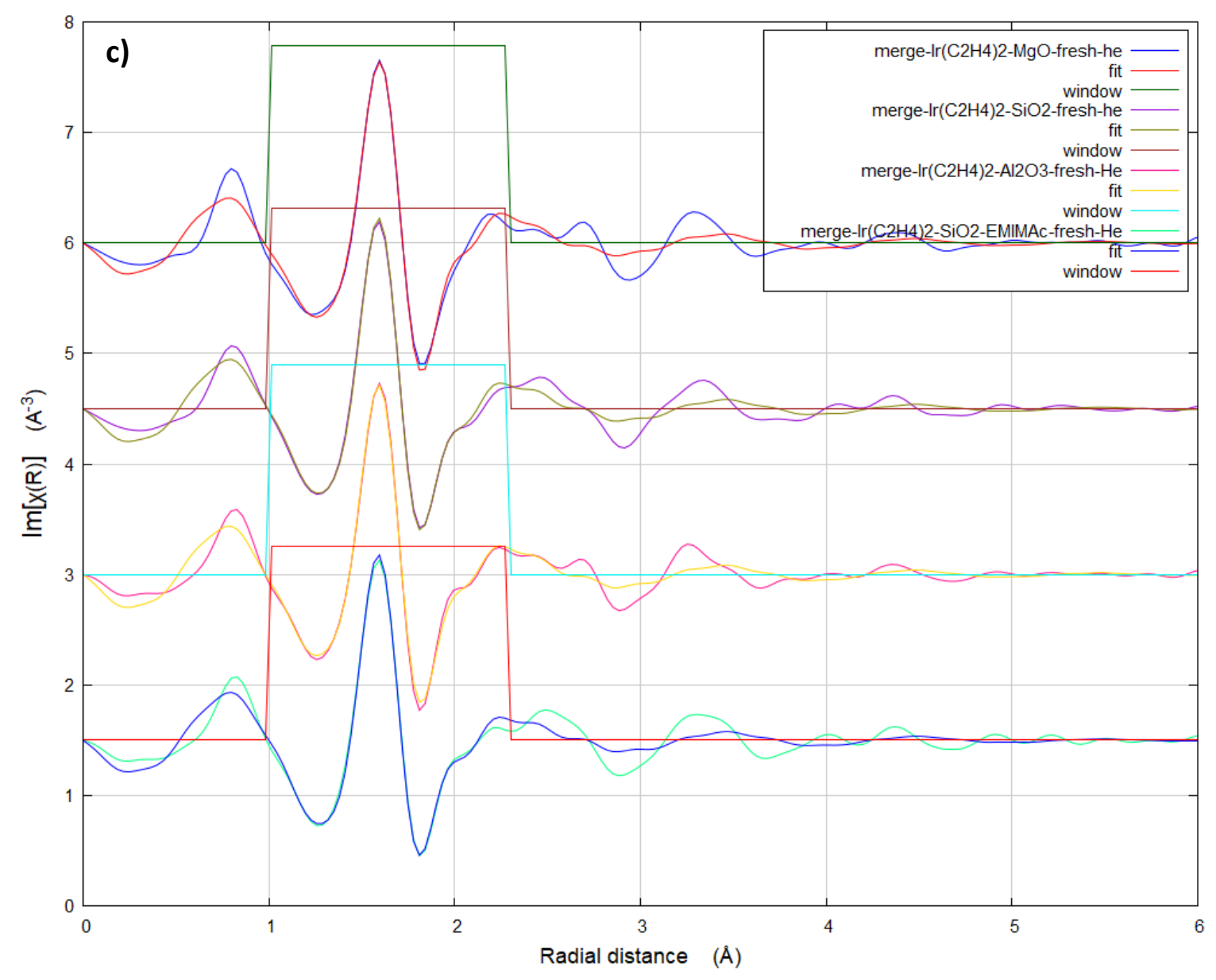

Figure S5. Results of EXAFS analysis by ARTEMIS characterizing the as-prepared samples: a) $k^{2}$-weighted EXAFS function and the best-fit EXAFS model, b) $k^{2}$-weighted magnitude of the Fourier-transform of the EXAFS and the best fit model, c) $k^{2}$-weighted imaginary component of the Fourier-transform of the EXAFS and the best fit model. From top to bottom in a): [EMIM][OAc]-coated $\operatorname{Ir}\left(\mathrm{C}_{2} \mathrm{H}_{4}\right)_{2} / \mathrm{SiO}_{2} ; \operatorname{Ir}\left(\mathrm{C}_{2} \mathrm{H}_{4}\right)_{2} / \gamma-\mathrm{Al}_{2} \mathrm{O}_{3} ; \operatorname{Ir}\left(\mathrm{C}_{2} \mathrm{H}_{4}\right)_{2} / \mathrm{SiO}_{2} ; \operatorname{Ir}\left(\mathrm{C}_{2} \mathrm{H}_{4}\right)_{2} / \mathrm{MgO}$. From top to bottom in b) and c): $\operatorname{Ir}\left(\mathrm{C}_{2} \mathrm{H}_{4}\right)_{2} / \mathrm{MgO} ; \operatorname{Ir}\left(\mathrm{C}_{2} \mathrm{H}_{4}\right)_{2} / \mathrm{SiO}_{2} ; \operatorname{Ir}\left(\mathrm{C}_{2} \mathrm{H}_{4}\right)_{2} / \gamma-\mathrm{Al}_{2} \mathrm{O}_{3}$; [EMIM][OAc]-coated $\operatorname{Ir}\left(\mathrm{C}_{2} \mathrm{H}_{4}\right)_{2} / \mathrm{SiO}_{2}$. Data were collected with samples in flowing helium $(20 \mathrm{ml} / \mathrm{min})$ at room temperature.

As an alternative to the fit models obtained for the as-prepared samples by using ARTEMIS, fitting was also performed by using XDAP by applying the difference-file technique on a representative data set characterizing the as-prepared $\gamma-\mathrm{Al}_{2} \mathrm{O}_{3}$-supported $\operatorname{Ir}\left(\mathrm{C}_{2} \mathrm{H}_{4}\right)_{2}$ complex. The best-fit model consistently indicated the lack of any $\mathrm{Ir}-\mathrm{Ir}$ contribution. Fitting with the difference-file technique resolved the individual contributions associated with the low-Zscatterers as i) an Ir-C shell with a coordination number of 3.9 and at a distance of $2.06 \AA$, ii) an $\mathrm{Ir}-\mathrm{O}$ shell with a coordination number of 2.3 and at a distance of $2.12 \AA$, iii) an $\mathrm{Ir}-\mathrm{Al}$ and an I $\mathrm{r}-\mathrm{O}_{\mathrm{L}}$ (where $\mathrm{L}$ stands for a long-distance $\mathrm{O}$ neighbor) shells at relatively long distances of 2.99 and $3.66 \AA$, respectively, added tentatively to improve the fit quality (Table S2, Figure S6). These results are broadly consistent with the previous works reporting XDAP fit models on analogous atomically dispersed $\operatorname{Ir}\left(\mathrm{C}_{2} \mathrm{H}_{4}\right)_{2}$ complexes supported on various supports. ${ }^{5-6,25}$ 
Table S2. Summary of best-fit four-shell EXAFS model of the as-prepared structure $\operatorname{Ir}\left(\mathrm{C}_{2} \mathrm{H}_{4}\right)_{2} / \gamma$ $\mathrm{Al}_{2} \mathrm{O}_{3}$ obtained by using XDAP. Data were collected in flowing $\mathrm{He}(20 \mathrm{ml} / \mathrm{min})$ at room temperature prior to the start of the TPR run.

\begin{tabular}{llllllll}
\hline Model & $\begin{array}{l}\text { Absorber- } \\
\text { Backscatter } \\
\text { Path }\end{array}$ & $\mathbf{C . N .} .^{\mathbf{a}}$ & $\begin{array}{l}\mathbf{1 0}^{3} \times \mathbf{\sigma}^{\mathbf{2 b}} \\
\left(\AA^{2}\right)\end{array}$ & $\begin{array}{l}\mathbf{R}^{\mathbf{c}} \\
(\AA)\end{array}$ & $\begin{array}{l}\Delta \mathrm{E}_{0}{ }^{\mathbf{d}} \\
(\mathbf{e V})\end{array}$ & $\begin{array}{l}\boldsymbol{k} \text {-range } \\
\left(\AA^{-1}\right)\end{array}$ & $\begin{array}{l}\boldsymbol{R} \text {-range } \\
(\AA)\end{array}$ \\
\hline \multirow{3}{*}{ Four-shell model } & Ir-O & 2.3 & 5.4 & 2.12 & 7.9 & & \\
& Ir-C & 3.9 & 5.3 & 2.06 & -5.6 & $3.1-13.4$ & $1.0-3.5$ \\
& Ir-Al & 1.0 & 8.5 & 2.99 & 2.6 & & \\
& Ir-OL & 3.9 & 13.3 & 3.66 & -1.5 & & \\
\hline
\end{tabular}

${ }^{a}$ Coordination number, ${ }^{b}$ disorder in neighbor distance, cabsorber-backscatter distance, ${ }^{\mathrm{d} e n e r g y ~ s h i f t . ~ T h e ~}$ accuracies of the parameters obtained by XDAP fitting are estimated to be as follows: coordination number $N, \pm 20 \%$ for Ir-low-Z scatterer contributions, $\pm 10 \%$ for Ir-high-Z scatterer contributions; distance $R, \pm 0.02 \AA$; disorder term $\Delta \sigma^{2}, \pm 20 \%$; and inner potential correction $\Delta E_{0}, \pm 20 .{ }^{13} \mathrm{~L}$ in Ir-O L stands for a long-distance O neighbor.
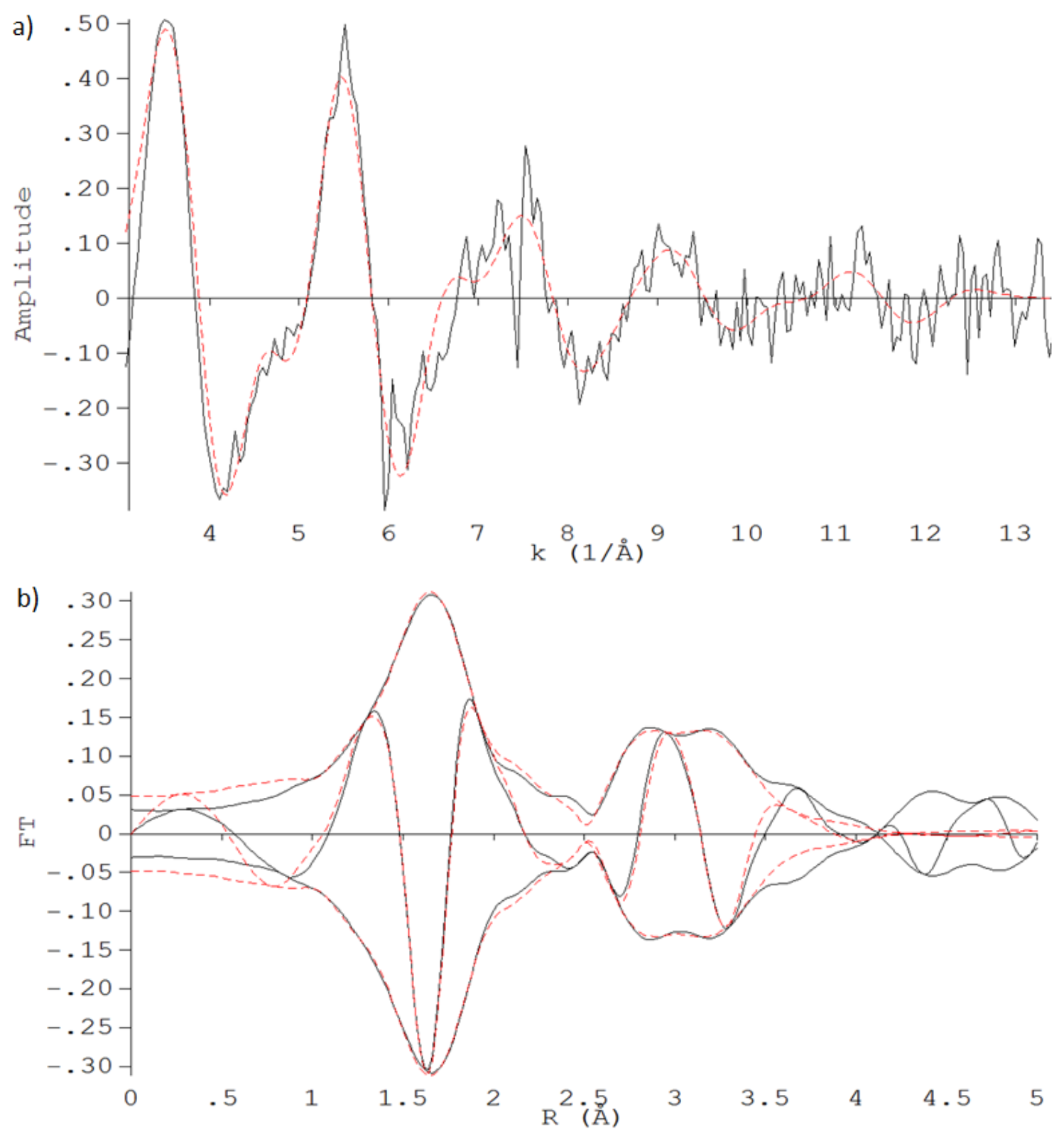

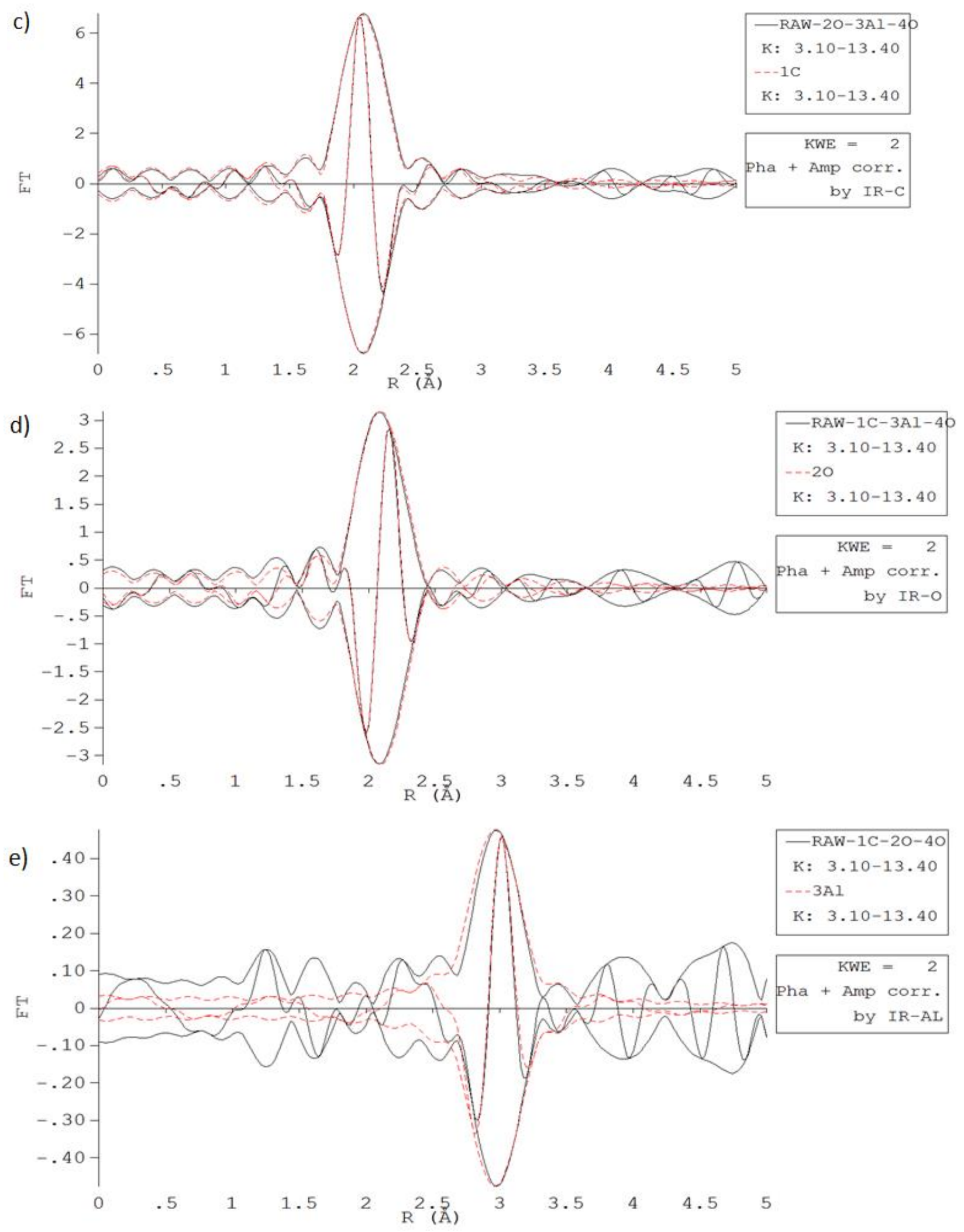


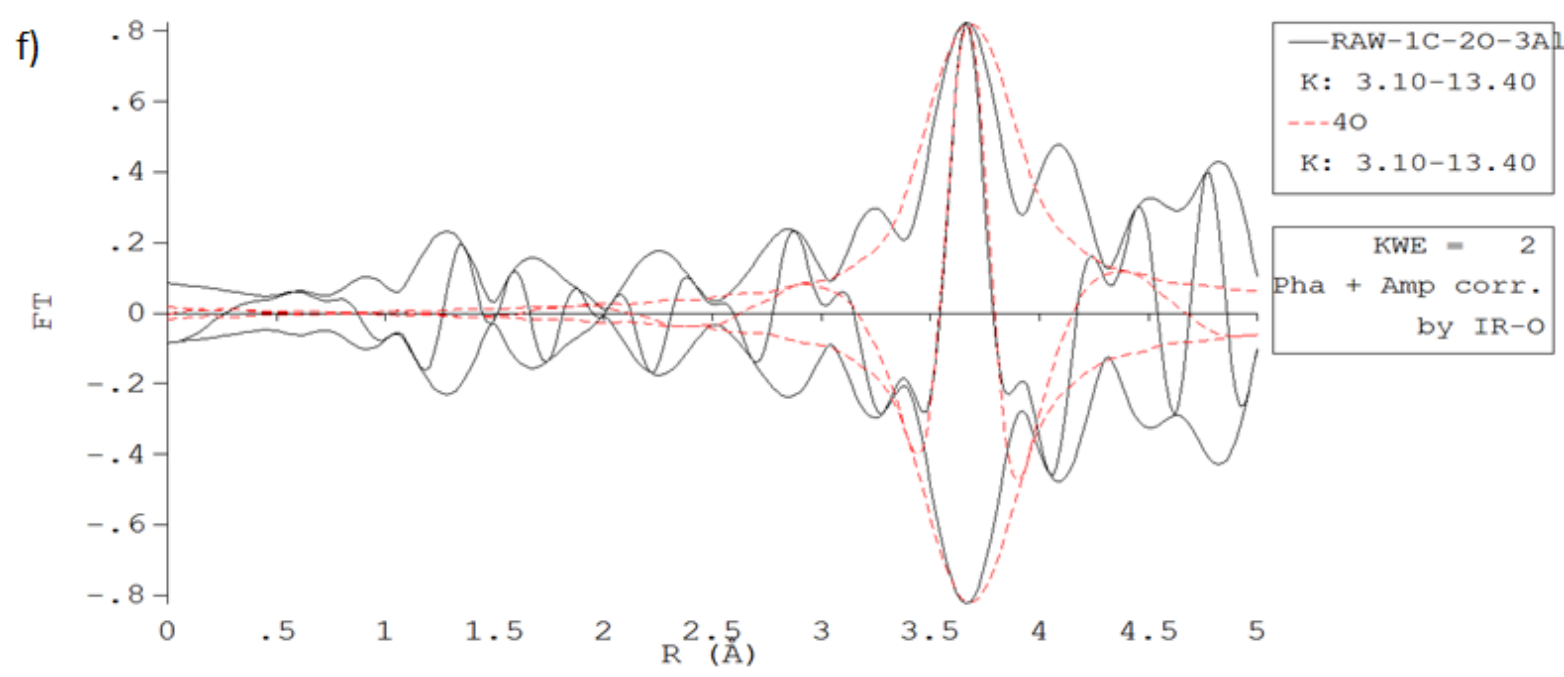

Figure S6. Results of EXAFS analysis by using the four-shell model in XDAP characterizing the as-prepared sample formed by the reaction of $\gamma-\mathrm{Al}_{2} \mathrm{O}_{3}$ (calcined at $500{ }^{\circ} \mathrm{C}$ ) with $\operatorname{Ir}\left(\mathrm{C}_{2} \mathrm{H}_{4}\right)_{2}$ (acac) in $n$-pentane after removal of the solvent: a) $k^{2}$-weighted EXAFS function, $\chi$, (solid line), and calculated contribution (dotted line), b) $k^{2}$-weighted imaginary part and magnitude of the Fourier-transform of data (solid line), and calculated contribution (dotted line), c) $k^{2}$-weighted imaginary part and magnitude of phase- and amplitude-corrected Fourier transform of data minus $\mathrm{Ir}-\mathrm{O}, \mathrm{Ir}-\mathrm{Al}$, and $\mathrm{Ir}-\mathrm{O}_{\mathrm{L}}$ (where $\mathrm{L}$ stands for a long-distance $\mathrm{O}$ neighbor) contributions (solid line) and calculated Ir-C contribution (dotted line), d) $k^{2}$-weighted imaginary part and magnitude of phase- and amplitude-corrected Fourier transform of data minus Ir-C, $\mathrm{Ir}-\mathrm{Al}$, and Ir-O $\mathrm{O}$ contributions (solid line) and calculated Ir-O contribution (dotted line), e) $k^{2}$ weighted imaginary part and magnitude of phase- and amplitude-corrected Fourier transform of data minus Ir-O, Ir-C, and Ir-O $\mathrm{L}$ contributions (solid line) and calculated Ir-Al contribution (dotted line), f) $k^{2}$-weighted imaginary part and magnitude of phase- and amplitude-corrected Fourier transform of data minus Ir-C, Ir-O, and Ir-Al contributions (solid line) and calculated Ir-O $\mathrm{L}$ contribution (dotted line). Data were collected with samples in flowing helium $(20 \mathrm{ml} / \mathrm{min})$ at room temperature prior to the start of the TPR treatment.

\section{S2.3. IR spectra of as-prepared $\operatorname{Ir}(\mathrm{CO})_{2}$ complexes on each support}

Figure $\mathrm{S} 7$ compares the symmetric and antisymmetric $v(\mathrm{CO})$ bands of the as-prepared supported $\operatorname{Ir}(\mathrm{CO})_{2}$ complexes along with an [EMIM][OAc]-coated $\mathrm{SiO}_{2}$-supported $\operatorname{Ir}(\mathrm{CO})_{2}$ complex. For instance, the $\operatorname{Ir}(\mathrm{CO})_{2}$ complex supported on $\mathrm{MgO}$ is characterized with the bands located at 2068 and $1985 \mathrm{~cm}^{-1}$ associated with $v(\mathrm{CO})_{\text {sym }}$ and $v(\mathrm{CO})_{\text {asym }}$ features, respectively. Upon coating $\operatorname{Ir}(\mathrm{CO})_{2} / \mathrm{SiO}_{2}$ with [EMIM][OAc], the $v(\mathrm{CO})_{\text {sym }}$ band significantly red-shifted from 2081 to $2050 \mathrm{~cm}^{-1}$ (Figure S7), similar to a previously reported 1- $n$-butyl-3-methylimidazolium acetate ([BMIM][OAc])-coated $\mathrm{SiO}_{2}$-supported $\operatorname{Ir}(\mathrm{CO})_{2}$ complex, ${ }^{29}$ which is because of the electron donation from the IL to the metal. ${ }^{32}$ In summary, according to the spectra presented in Figure S7 the electron density on Ir increases in the following order: $\operatorname{Ir}(\mathrm{CO})_{2} / \mathrm{SiO}_{2}<\operatorname{Ir}(\mathrm{CO})_{2} / \gamma$ $\mathrm{Al}_{2} \mathrm{O}_{3}<\operatorname{Ir}(\mathrm{CO})_{2} / \mathrm{MgO}<[\mathrm{EMIM}][\mathrm{OAc}]$-coated $\operatorname{Ir}(\mathrm{CO})_{2} / \mathrm{SiO}_{2}$. The spectrum of [EMIM][OAc]coated $\mathrm{SiO}_{2}$-supported $\operatorname{Ir}(\mathrm{CO})_{2}$ complex shows an additional peak at $2006 \mathrm{~cm}^{-1}$ (Figure S7), which is most probably due to the presence of the IL. A similar peak at $2006 \mathrm{~cm}^{-1}$ was observed for $\mathrm{SiO}_{2}$-supported $\operatorname{Ir}(\mathrm{CO})_{2}$ complex coated with an IL having the same anion, [BMIM][OAc]. ${ }^{29}$ 


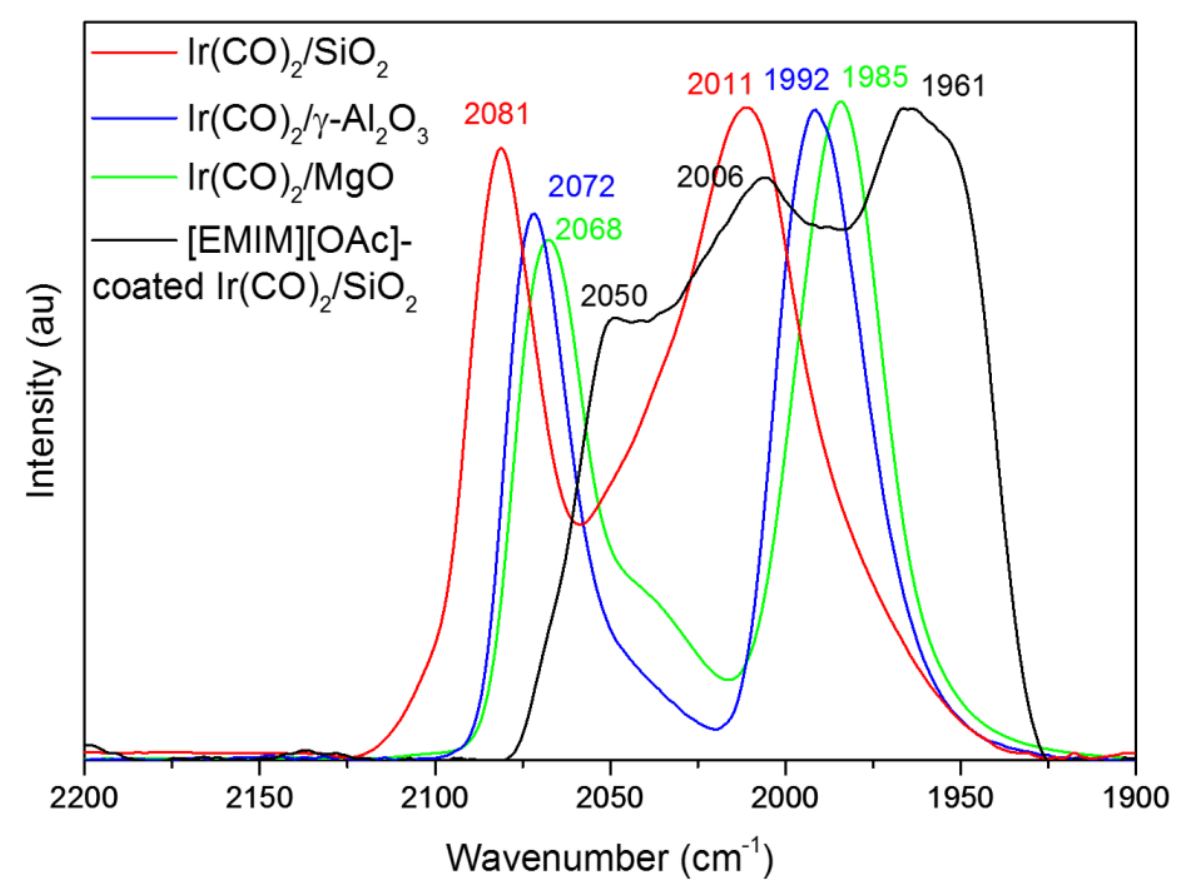

Figure S7. $v(\mathrm{CO})$ vibrations of $\mathrm{SiO}_{2^{-}}(\mathrm{red}), \gamma-\mathrm{Al}_{2} \mathrm{O}_{3^{-}}$(blue), MgO-supported $\operatorname{Ir}\left(\mathrm{C}_{2} \mathrm{H}_{4}\right)_{2}$ complexes (green), and [EMIM][OAc]-coated $\mathrm{SiO}_{2}$-supported $\operatorname{Ir}(\mathrm{CO})_{2}$ complex (black).

\section{S2.4. Computational results:}

Figure S8 and S9 illustrate the optimized geometries of the lowest-energy conformers obtained for $\mathrm{SiO}_{2^{-}}, \gamma-\mathrm{Al}_{2} \mathrm{O}_{3^{-}}$, and $\mathrm{MgO}$-supported $\operatorname{Ir}(\mathrm{CO})_{2}$ and $\operatorname{Ir}\left(\mathrm{C}_{2} \mathrm{H}_{4}\right)_{2}$ complexes, respectively. As described in detail in the experimental and computational methods section, the $\mathrm{SiO}_{2}$ supported complexes were simulated using a tetrahedral arrangement (Figure S8a, Figure S9a). The crystal structure displayed for the $\gamma-\mathrm{Al}_{2} \mathrm{O}_{3}$-supported complexes consists of 4,6 and 8 membered rings. It turns out that the structure for which $\operatorname{Ir}\left(\mathrm{C}_{2} \mathrm{H}_{4}\right)_{2}$ and $\operatorname{Ir}(\mathrm{CO})_{2}$ faces the octagonal face of the crystal is more stable and in good agreement with the experimental results than the others (Figure S8b, Figure 9b). For the MgO-supported complexes, the (100) crystal, where Ir atoms bond to the terrace sites through $2 \mathrm{Ir}-\mathrm{O}$ have reproduced the experimental findings ${ }^{22}$ (Figure S8c, Figure 9c).
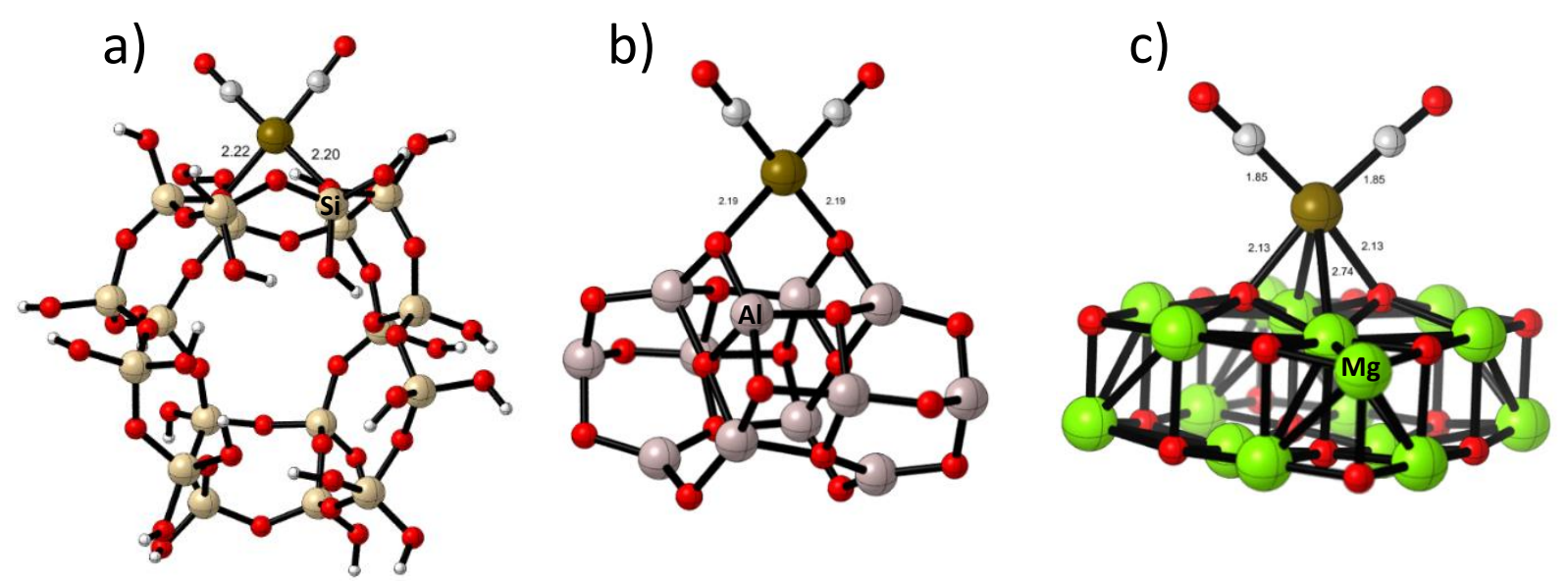

Figure S8. Optimized structures of a) $\mathrm{SiO}_{2^{-}}$, b) $\gamma-\mathrm{Al}_{2} \mathrm{O}_{3^{-}}$, and c) $\mathrm{MgO}$-supported $\operatorname{Ir}(\mathrm{CO})_{2}$ complexes (PBE/6-31G(d,p)). Selected distances are given in $\AA$. 

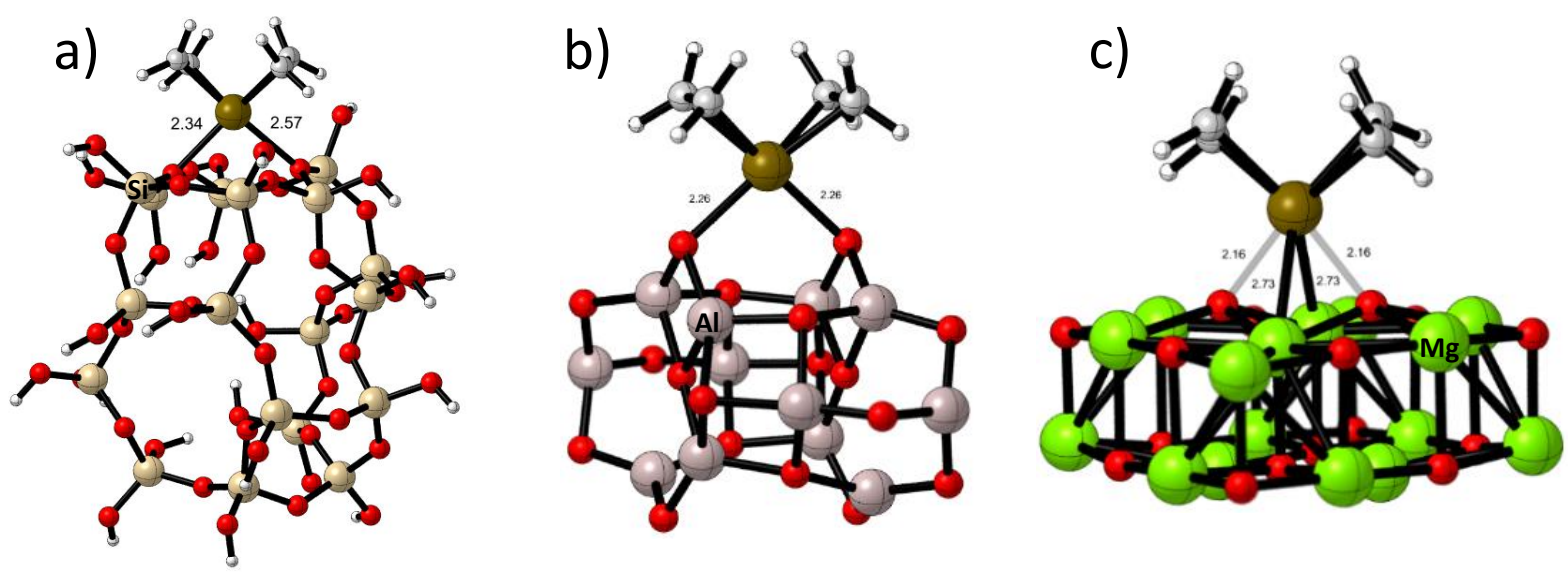

Figure S9. Optimized structures of a) $\mathrm{SiO}_{2^{-}}$, b) $\gamma-\mathrm{Al}_{2} \mathrm{O}_{3^{-}}$, and c) $\mathrm{MgO}$-supported $\operatorname{Ir}\left(\mathrm{C}_{2} \mathrm{H}_{4}\right)_{2}$ complexes (PBE/6-31G(d,p)). Selected distances are given in $\AA$.

Table S3 shows the calculated $v(\mathrm{CO})_{\text {sym }}$ band positions in comparison with the experimentally determined positions. The $v(\mathrm{CO})_{\text {sym }}$ bands were computationally determined as 2091, 2086, and 2054 after using a scaling factor of $0.986 .{ }^{24}$ Data show that the calculated $v(\mathrm{CO})_{\text {sym }}$ band positions decrease in the following order of the supports: $\mathrm{SiO}_{2}>\gamma-\mathrm{Al}_{2} \mathrm{O}_{3}>\mathrm{MgO}$. This order is in accordance with the order of the experimental $v(\mathrm{CO})_{\text {sym }}$ band positions as represented in Figure S7 (Table S3).

Table S3. Computationally and experimentally determined $v(C O)_{\text {sym }}$ band positions for supported $\operatorname{Ir}(\mathrm{CO})_{2}$ complexes (PBE/6-31G(d,p)).

\begin{tabular}{lcc}
\hline Sample & $\begin{array}{c}\text { Calculated } \\
v(\mathbf{C O})_{\text {sym }}\left(\mathbf{c m}^{-1}\right)\end{array}$ & $\begin{array}{c}\text { Experimental } \\
v(\mathbf{C O})_{\text {sym }}\left(\mathbf{c m}^{-1}\right)\end{array}$ \\
\hline $\operatorname{Ir}(\mathrm{CO})_{2} / \mathrm{SiO}_{2}$ & 2091 & 2081 \\
$\operatorname{Ir}(\mathrm{CO})_{2} / \gamma-\mathrm{Al}_{2} \mathrm{O}_{3}$ & 2086 & 2072 \\
$\operatorname{Ir}(\mathrm{CO})_{2} / \mathrm{MgO}$ & 2054 & 2068 \\
\hline
\end{tabular}

Table S4 represents the determined charges on $\operatorname{Ir}$ atoms in the $\operatorname{Ir}(\mathrm{CO})_{2}$ and $\operatorname{Ir}\left(\mathrm{C}_{2} \mathrm{H}_{4}\right)_{2}$ complexes supported on $\mathrm{SiO}_{2}, \gamma-\mathrm{Al}_{2} \mathrm{O}_{3}$, and $\mathrm{MgO}$ by using the $\mathrm{CM} 5$ and the Hirshfeld charge analysis. Data show that the charge on iridium atom decreases with an increase in the electrondonor strength of the support for both type of complexes. Thus, we infer that the electron density of the Ir atom in the supported $\operatorname{Ir}\left(\mathrm{C}_{2} \mathrm{H}_{4}\right)_{2}$ complexes increase in the following order of the supports: $\mathrm{SiO}_{2}<\gamma-\mathrm{Al}_{2} \mathrm{O}_{3}<\mathrm{MgO}$ (Table S4). This order is consistent with the inference derived from the corresponding $v(\mathrm{CO})$ band positions of the $\mathrm{SiO}_{2^{-}}, \gamma-\mathrm{Al}_{2} \mathrm{O}_{3}$, and $\mathrm{MgO}$-supported $\operatorname{Ir}(\mathrm{CO})_{2}$ complexes given in Figure S7 and with the calculated positions presented in Table S3.

Table S4. Charge distributions on $\operatorname{Ir}$ atom in supported $\operatorname{Ir}(\mathrm{CO})_{2}$ and $\operatorname{Ir}\left(\mathrm{C}_{2} \mathrm{H}_{4}\right)_{2}$ complexes (PBE/6-31G(d,p)).

\begin{tabular}{lcc}
\hline & \multicolumn{2}{c}{ Charge on Ir atom } \\
\hline Sample & CM5 & Hirshfeld \\
\hline $\operatorname{Ir}(\mathrm{CO})_{2} / \mathrm{SiO}_{2}$ & 0.428 & 0.120 \\
$\operatorname{Ir}(\mathrm{CO})_{2} / \gamma-\mathrm{Al}_{2} \mathrm{O}_{3}$ & 0.404 & 0.106 \\
$\operatorname{Ir}(\mathrm{CO})_{2} / \mathrm{MgO}$ & 0.365 & 0.093 \\
$\operatorname{Ir}\left(\mathrm{C}_{2} \mathrm{H}_{4}\right)_{2} / \mathrm{SiO}_{2}$ & 0.479 & 0.204 \\
$\operatorname{Ir}\left(\mathrm{C}_{2} \mathrm{H}_{4}\right)_{2} / \gamma-\mathrm{Al}_{2} \mathrm{O}_{3}$ & 0.456 & 0.181 \\
$\operatorname{Ir}\left(\mathrm{C}_{2} \mathrm{H}_{4}\right)_{2} / \mathrm{MgO}$ & 0.405 & 0.154 \\
\hline
\end{tabular}




\section{S2.5. X-ray absorption near edge spectroscopy (XANES) results of as-prepared samples}

Figure S10 represents the XANES of the as-prepare samples. There is a slight shift in the absorption edge, determined by the inflection point of the adsorption edge, indicating differences in electronic environment in each sample.

a)

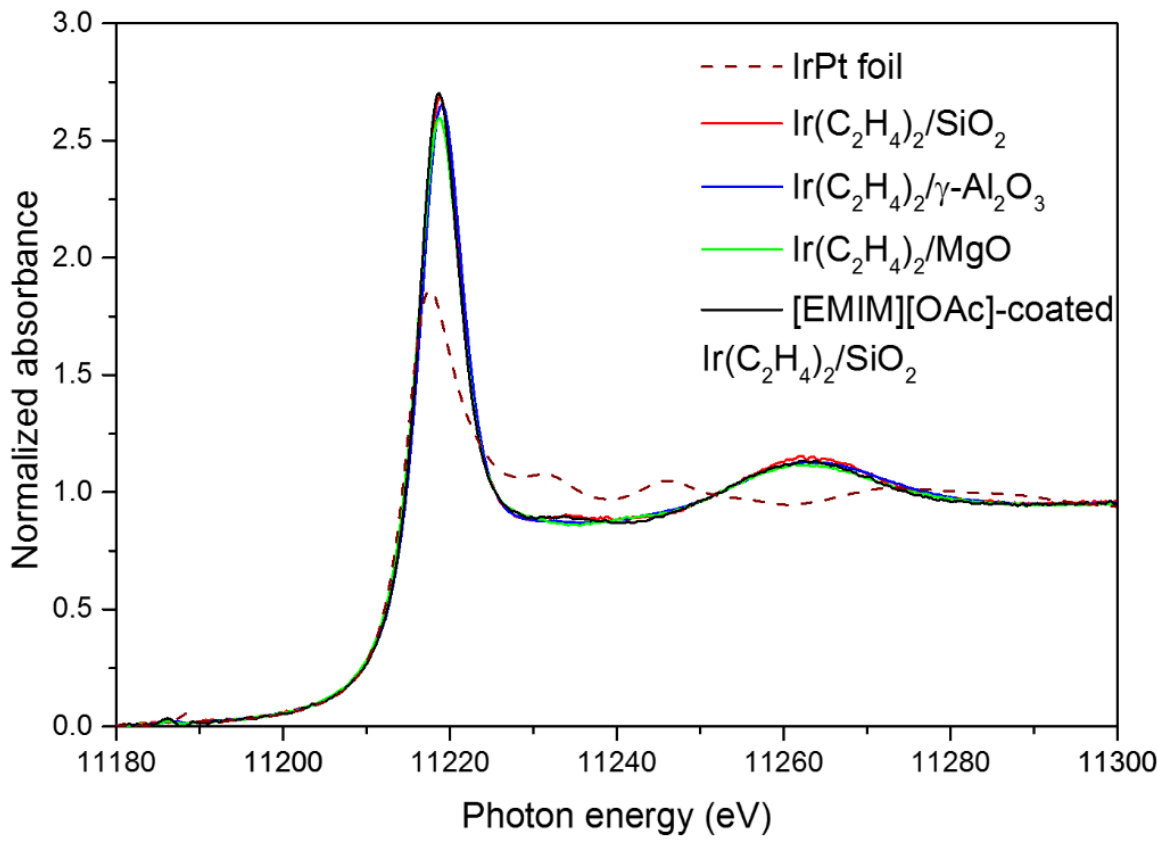

b)

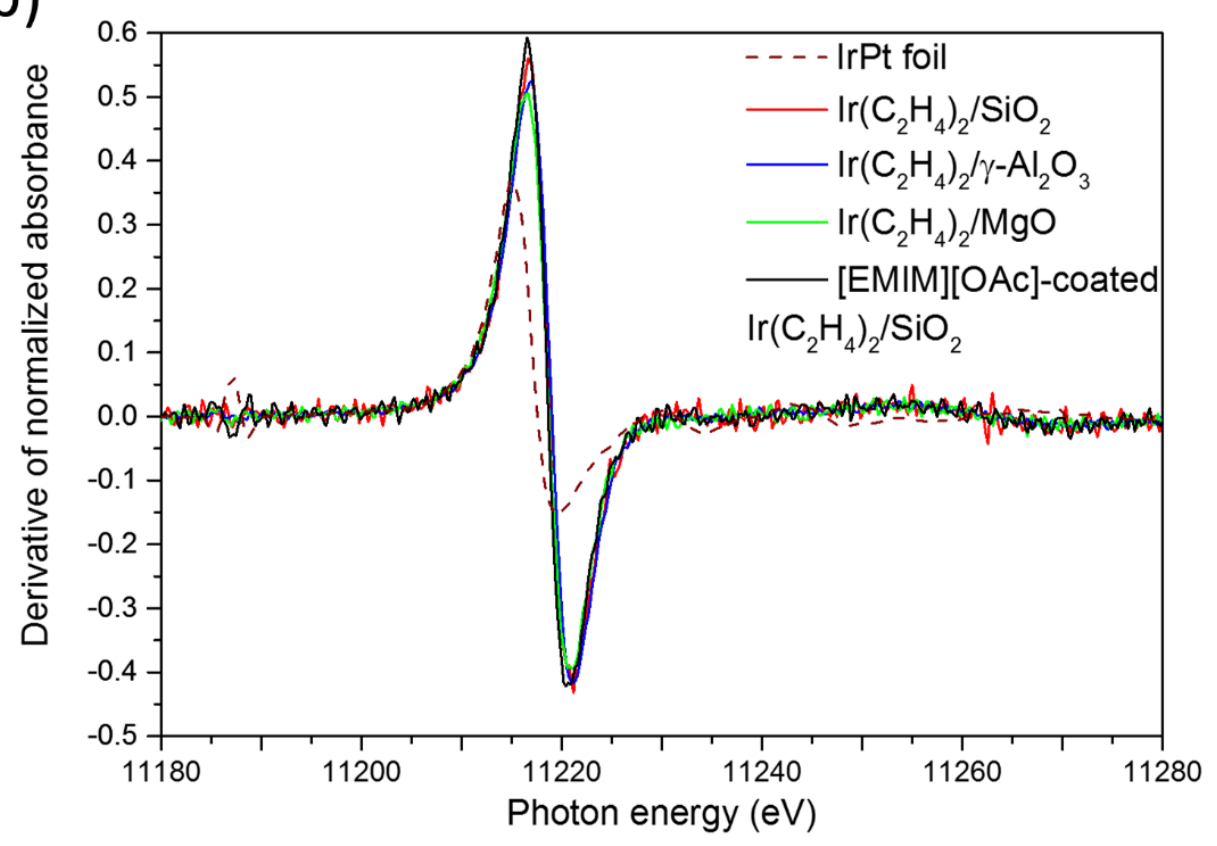

Figure S10. a) Normalized XANES spectra measured at the Ir $L_{11}$ edge and b) derivatives of the normalized XANES spectra of the as-prepared samples: $\mathrm{SiO}_{2^{-}}$(red), $\gamma-\mathrm{Al}_{2} \mathrm{O}_{3^{-}}$(blue), $\mathrm{MgO}$ supported (green) $\operatorname{Ir}\left(\mathrm{C}_{2} \mathrm{H}_{4}\right)_{2}$ complexes, and [EMIM][OAc]-coated $\mathrm{SiO}_{2}$-supported (black) $\operatorname{Ir}\left(\mathrm{C}_{2} \mathrm{H}_{4}\right)_{2}$ complex. 
S2.6. XANES results recorded during a temperature ramp to $120{ }^{\circ} \mathrm{C}$ in flowing $\mathrm{H}_{2}$

a)

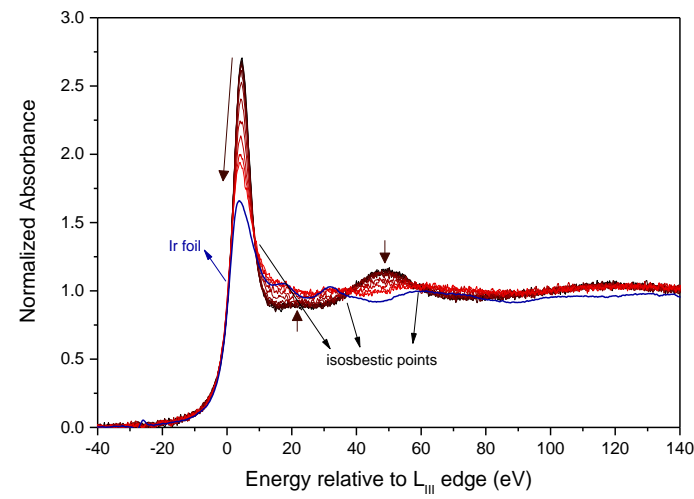

b)

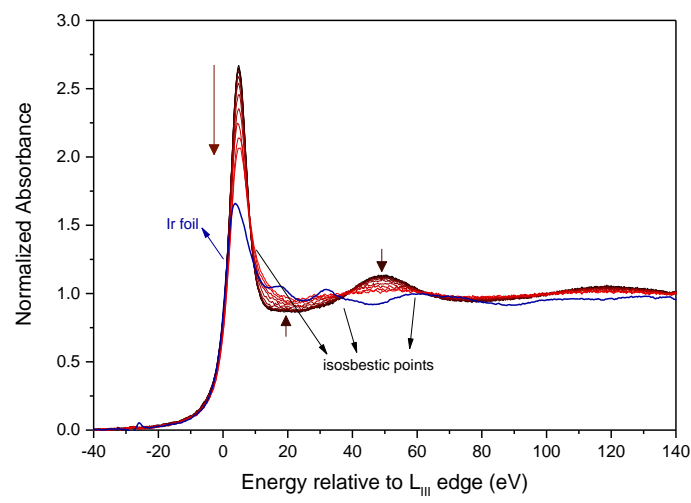

c)

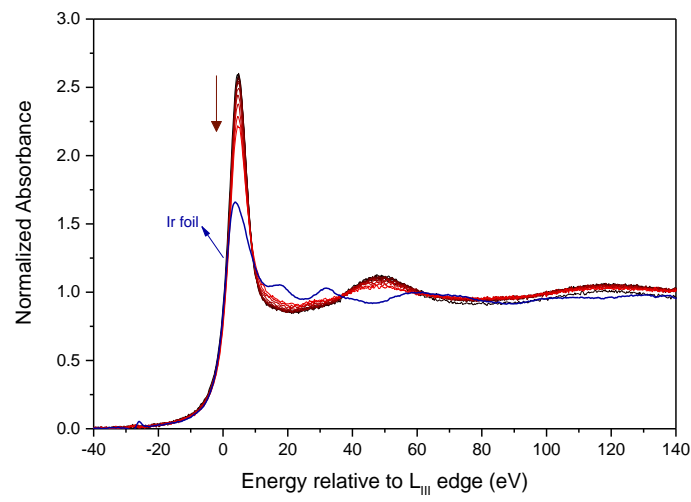

d)

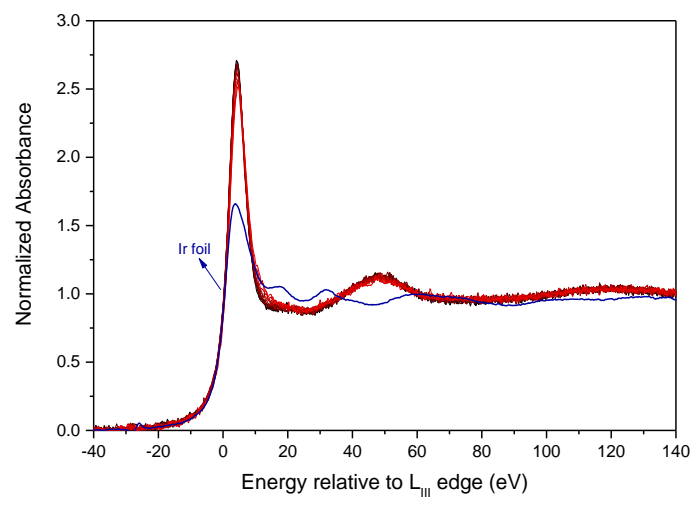

Figure S11. Normalized XANES spectra at Ir $L_{\text {III }}$ edge obtained real-time during a temperature ramp in pure flowing $\mathrm{H}_{2}$ up to $120{ }^{\circ} \mathrm{C}$ for a) $\mathrm{SiO}_{2^{-}}$, b) $\gamma-\mathrm{Al}_{2} \mathrm{O}_{3^{-}}$, c) $\mathrm{MgO}$-supported $\operatorname{Ir}\left(\mathrm{C}_{2} \mathrm{H}_{4}\right)_{2}$ complexes, and d) [EMIM][OAc]-coated $\mathrm{SiO}_{2}$-supported $\operatorname{Ir}\left(\mathrm{C}_{2} \mathrm{H}_{4}\right)_{2}$ complex. 
S2.7. EXAFS results recorded during a temperature ramp to $120^{\circ} \mathrm{C}$ in flowing $\mathrm{H}_{2}$
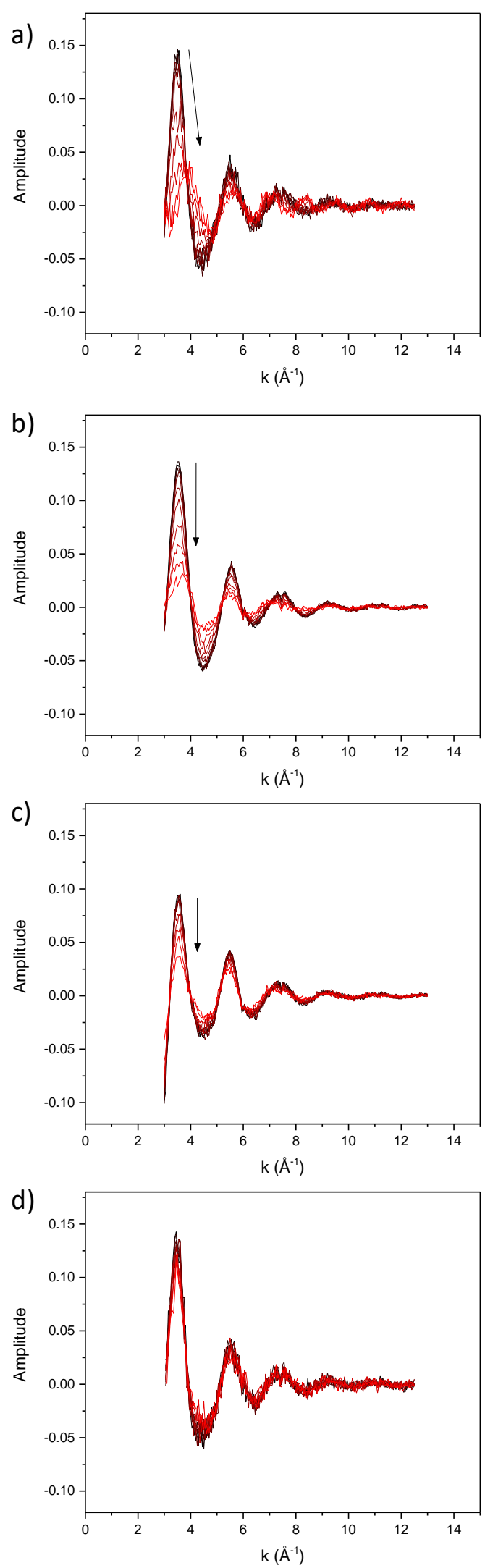

Figure S12. Unweighted EXAFS function, $\chi$, obtained real-time during a temperature ramp in pure flowing $\mathrm{H}_{2}$ up to $120^{\circ} \mathrm{C}$ for a) $\mathrm{SiO}_{2^{-}}$, b) $\gamma-\mathrm{Al}_{2} \mathrm{O}_{3^{-}}$, c) $\mathrm{MgO}$-supported $\operatorname{Ir}\left(\mathrm{C}_{2} \mathrm{H}_{4}\right)_{2}$ complexes, and d) [EMIM][OAc]-coated $\mathrm{SiO}_{2}$-supported $\operatorname{Ir}\left(\mathrm{C}_{2} \mathrm{H}_{4}\right)_{2}$ complex. 

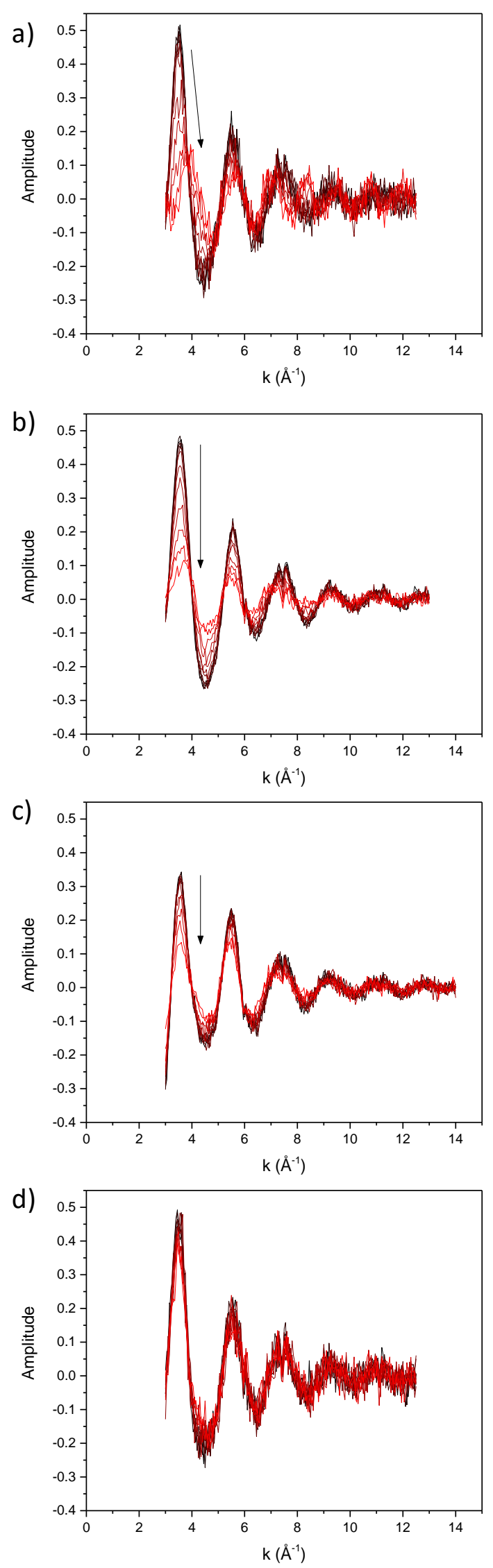

Figure S13. $k^{1}$-weighted EXAFS function, $\chi$, obtained real-time during a temperature ramp in pure flowing $\mathrm{H}_{2}$ up to $120^{\circ} \mathrm{C}$ for a) $\mathrm{SiO}_{2^{-}}$, b) $\gamma-\mathrm{Al}_{2} \mathrm{O}_{3^{-}}$, c) MgO-supported $\operatorname{Ir}\left(\mathrm{C}_{2} \mathrm{H}_{4}\right)_{2}$ complexes, and d) [EMIM][OAc]-coated $\mathrm{SiO}_{2}$-supported $\operatorname{Ir}\left(\mathrm{C}_{2} \mathrm{H}_{4}\right)_{2}$ complex.

SI-20 

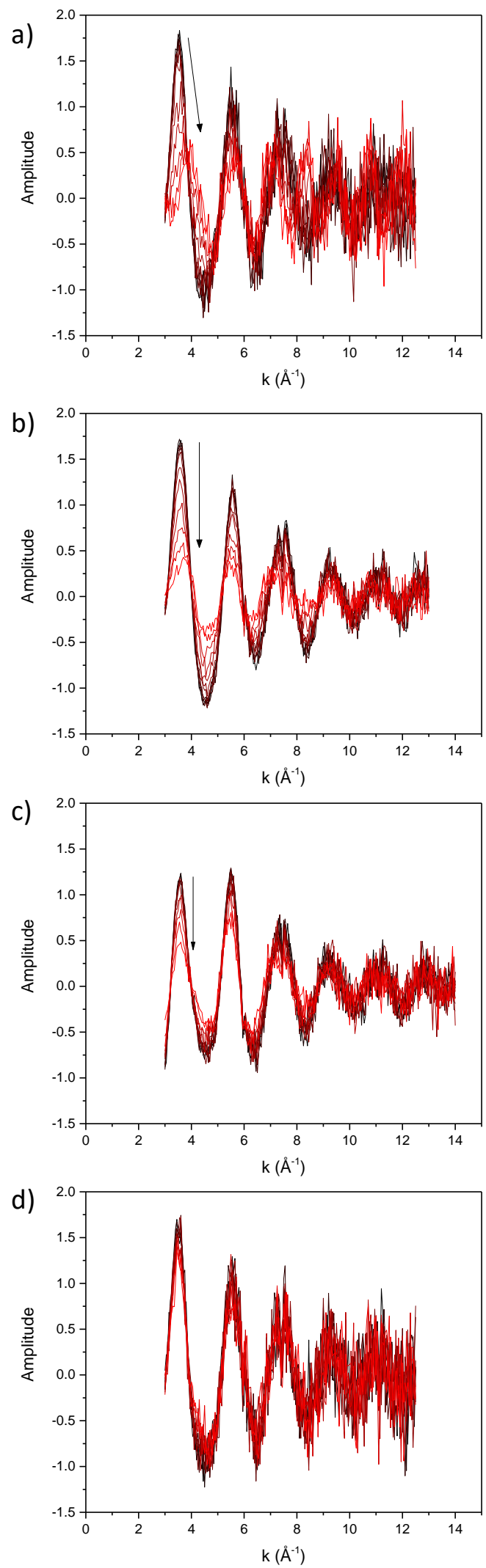

Figure S14. $k^{2}$-weighted EXAFS function, $\chi$, obtained real-time during a temperature ramp in pure flowing $\mathrm{H}_{2}$ up to $120^{\circ} \mathrm{C}$ for a) $\mathrm{SiO}_{2^{-}}$, b) $\gamma-\mathrm{Al}_{2} \mathrm{O}_{3^{-}}$, c) $\mathrm{MgO}$-supported $\operatorname{Ir}\left(\mathrm{C}_{2} \mathrm{H}_{4}\right)_{2}$ complexes, and d) [EMIM][OAc]-coated $\mathrm{SiO}_{2}$-supported $\operatorname{Ir}\left(\mathrm{C}_{2} \mathrm{H}_{4}\right)_{2}$ complex. 

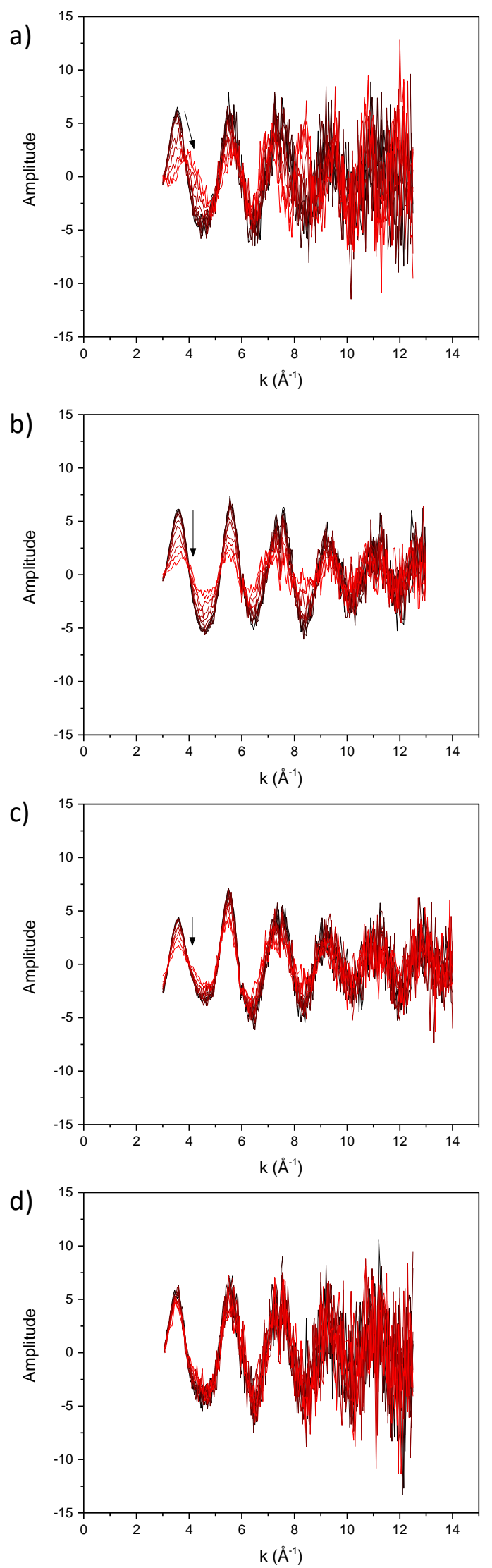

Figure S15. $k^{3}$-weighted EXAFS function, $\chi$, obtained real-time during a temperature ramp in pure flowing $\mathrm{H}_{2}$ up to $120^{\circ} \mathrm{C}$ for a) $\mathrm{SiO}_{2^{-}}$, b) $\gamma-\mathrm{Al}_{2} \mathrm{O}_{3^{-}}$, c) $\mathrm{MgO}$-supported $\operatorname{Ir}\left(\mathrm{C}_{2} \mathrm{H}_{4}\right)_{2}$ complexes, and d) [EMIM][OAc]-coated $\mathrm{SiO}_{2}$-supported $\operatorname{Ir}\left(\mathrm{C}_{2} \mathrm{H}_{4}\right)_{2}$ complex. 
Table S5. $\Delta k$ ranges used to obtain the magnitude of the Fourier-transform of the EXAFS spectra presented in Figure 2. The temperature was measured at the back-end of the catalyst bed.

\begin{tabular}{|c|c|c|}
\hline Sample & $\begin{array}{c}\text { Approximate } \\
\text { temperature at } \\
\text { which the data } \\
\text { were obtained }\left({ }^{\circ} \mathrm{C}\right)\end{array}$ & $k$ range $\left(\AA^{-1}\right)$ \\
\hline \multirow{12}{*}{$\operatorname{Ir}\left(\mathrm{C}_{2} \mathrm{H}_{4}\right)_{2} / \mathrm{SiO}_{2}$} & 25.0 & $3.1-10.7$ \\
\hline & 33.6 & $3.1-10.6$ \\
\hline & 42.3 & $3.2-10.8$ \\
\hline & 50.9 & $3.1-10.1$ \\
\hline & 59.6 & $3.1-10.3$ \\
\hline & 68.2 & $3.1-10.0$ \\
\hline & 76.8 & $3.1-12.5$ \\
\hline & 85.5 & $3.1-11.2$ \\
\hline & 94.1 & $3.1-10.5$ \\
\hline & 102.7 & $3.2-11.1$ \\
\hline & 111.4 & $3.4-11.6$ \\
\hline & 120.0 & $3.5-11.5$ \\
\hline \multirow{12}{*}{$\operatorname{Ir}\left(\mathrm{C}_{2} \mathrm{H}_{4}\right)_{2} / \gamma-\mathrm{Al}_{2} \mathrm{O}_{3}$} & 25.0 & $3.0-13.0$ \\
\hline & 33.6 & $3.0-13.0$ \\
\hline & 42.3 & $3.0-13.0$ \\
\hline & 50.9 & $3.0-13.0$ \\
\hline & 59.6 & $3.0-13.0$ \\
\hline & 68.2 & $3.0-13.0$ \\
\hline & 76.8 & $3.0-13.0$ \\
\hline & 85.5 & $3.0-13.0$ \\
\hline & 94.1 & $3.0-13.0$ \\
\hline & 102.7 & $3.0-13.0$ \\
\hline & 111.4 & $3.0-13.0$ \\
\hline & 120.0 & $3.0-13.0$ \\
\hline \multirow[t]{12}{*}{$\operatorname{Ir}\left(\mathrm{C}_{2} \mathrm{H}_{4}\right)_{2} / \mathrm{MgO}$} & 25.0 & $3.1-13.4$ \\
\hline & 33.6 & $3.1-13.1$ \\
\hline & 42.3 & $3.1-13.9$ \\
\hline & 50.9 & $3.1-13.9$ \\
\hline & 59.6 & $2.4-14.2$ \\
\hline & 68.2 & $3.1-13.9$ \\
\hline & 76.8 & $3.1-13.9$ \\
\hline & 85.5 & $3.1-13.9$ \\
\hline & 94.1 & $3.1-13.9$ \\
\hline & 102.7 & $3.1-13.9$ \\
\hline & 111.4 & $3.1-13.9$ \\
\hline & 120.0 & $3.1-13.9$ \\
\hline [EMIM][OAc]-coated & 25.0 & $3.0-11.4$ \\
\hline \multirow[t]{11}{*}{$\operatorname{Ir}\left(\mathrm{C}_{2} \mathrm{H}_{4}\right)_{2} / \mathrm{SiO}_{2}$} & 33.6 & $3.0-11.4$ \\
\hline & 42.3 & $3.0-10.7$ \\
\hline & 50.9 & $3.0-12.2$ \\
\hline & 59.6 & $3.0-11.4$ \\
\hline & 68.2 & $3.0-11.4$ \\
\hline & 76.8 & $3.0-11.4$ \\
\hline & 85.5 & $3.0-11.4$ \\
\hline & 94.1 & $3.0-13.5$ \\
\hline & 102.7 & $3.0-13.0$ \\
\hline & 111.4 & $3.0-12.4$ \\
\hline & 120.0 & $3.0-12.4$ \\
\hline
\end{tabular}


S2.8. EXAFS results of post-TPR samples (following a temperature ramp to $120^{\circ} \mathrm{C}$ with samples in flowing $\mathrm{H}_{2}$ )

A comparison of the extracted EXAFS data of the samples following a temperature ramp to $120^{\circ} \mathrm{C}$ in flowing $\mathrm{H}_{2}$ is shown in Figure $\mathrm{S} 16$. While the local structure around the $\mathrm{Ir}$ on the as-prepared samples were similar (Figure S3 and S4), following the TPR, structures differ from one another (Figure S16 and S17). Continuous Cauchy Wavelet Transform (CCWTT) ${ }^{33}$ was applied to aid in identification of appropriate scattering paths for modeling of the EXAFS of the post-TPR samples, Figures S18-S20. The color map is normalized in each wavelet transform.

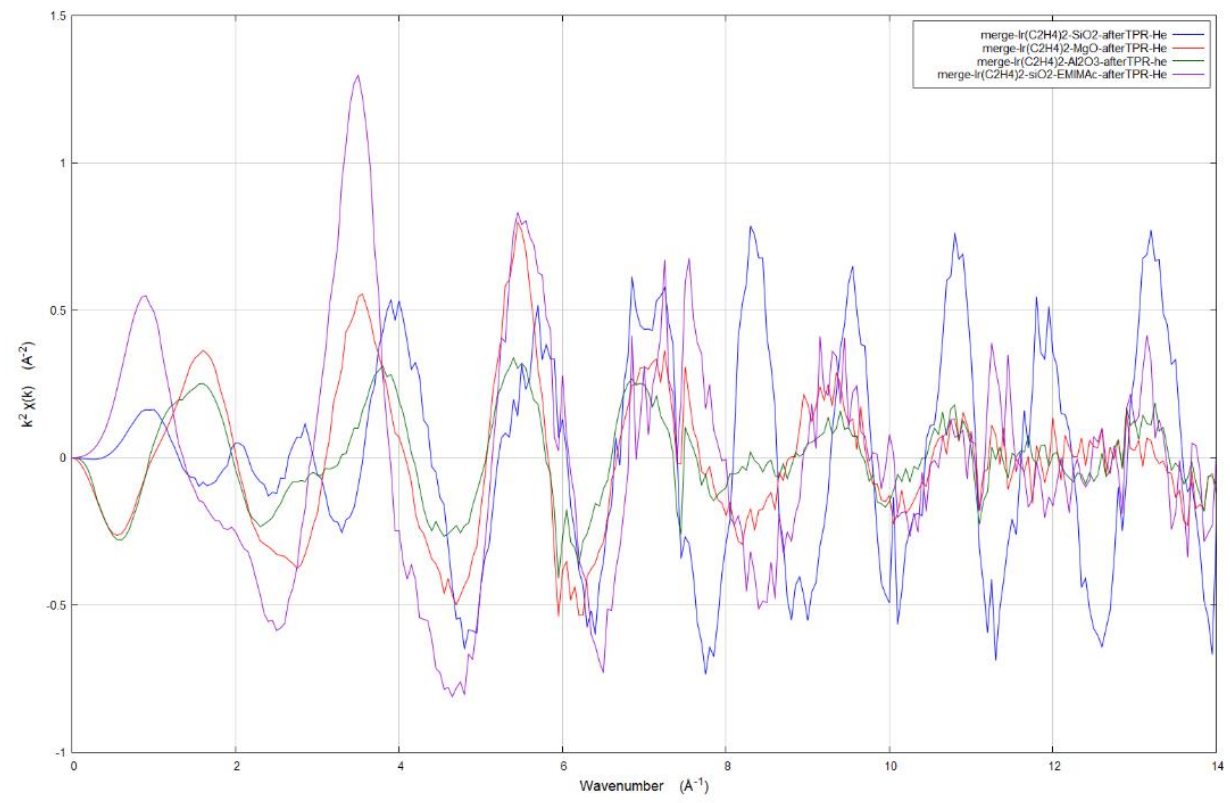

Figure S16. $k^{2}$-weighted EXAFS function, $\chi$, of all post-TPR samples collected at the Ir LilIedge: $\mathrm{SiO}_{2^{-}}$(blue), $\gamma-\mathrm{Al}_{2} \mathrm{O}_{3^{-}}$(green), MgO-supported $\operatorname{Ir}\left(\mathrm{C}_{2} \mathrm{H}_{4}\right)_{2}$ complexes (red), and [EMIM][OAc]-coated $\mathrm{SiO}_{2}$-supported (purple) $\operatorname{Ir}\left(\mathrm{C}_{2} \mathrm{H}_{4}\right)_{2}$ complexes. Spectra were obtained with samples in flowing helium $(20 \mathrm{ml} / \mathrm{min})$ at room temperature after a temperature ramp to 120 ${ }^{\circ} \mathrm{C}$ in flowing $\mathrm{H}_{2}$. 


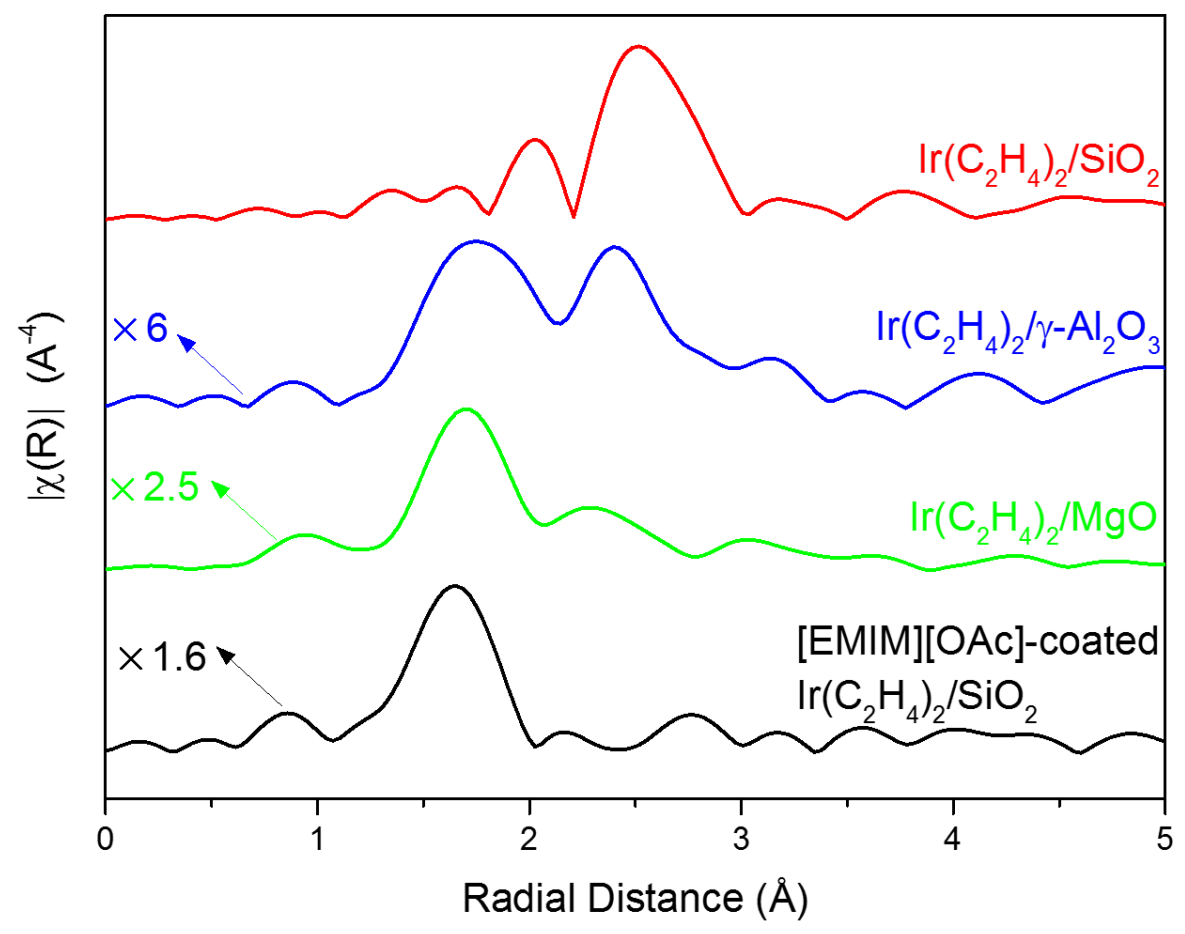

Figure S17. Magnitude of the Fourier transform ( $k^{3}$-weighted) of EXAFS spectra comparing the post-TPR structures of $\mathrm{SiO}_{2^{-}}$(red), $\mathrm{Al}_{2} \mathrm{O}_{3^{-}}$(green), $\mathrm{MgO}$-supported (blue), and [EMIM][OAc]-coated $\mathrm{SiO}_{2}$-supported (black) samples initially present as supported $\operatorname{Ir}\left(\mathrm{C}_{2} \mathrm{H}_{4}\right)_{2}$ complexes with spectra obtained after a temperature ramp from room temperature to $120^{\circ} \mathrm{C}$ with the sample in flowing $\mathrm{H}_{2}$ (spectra offset for clarity). 

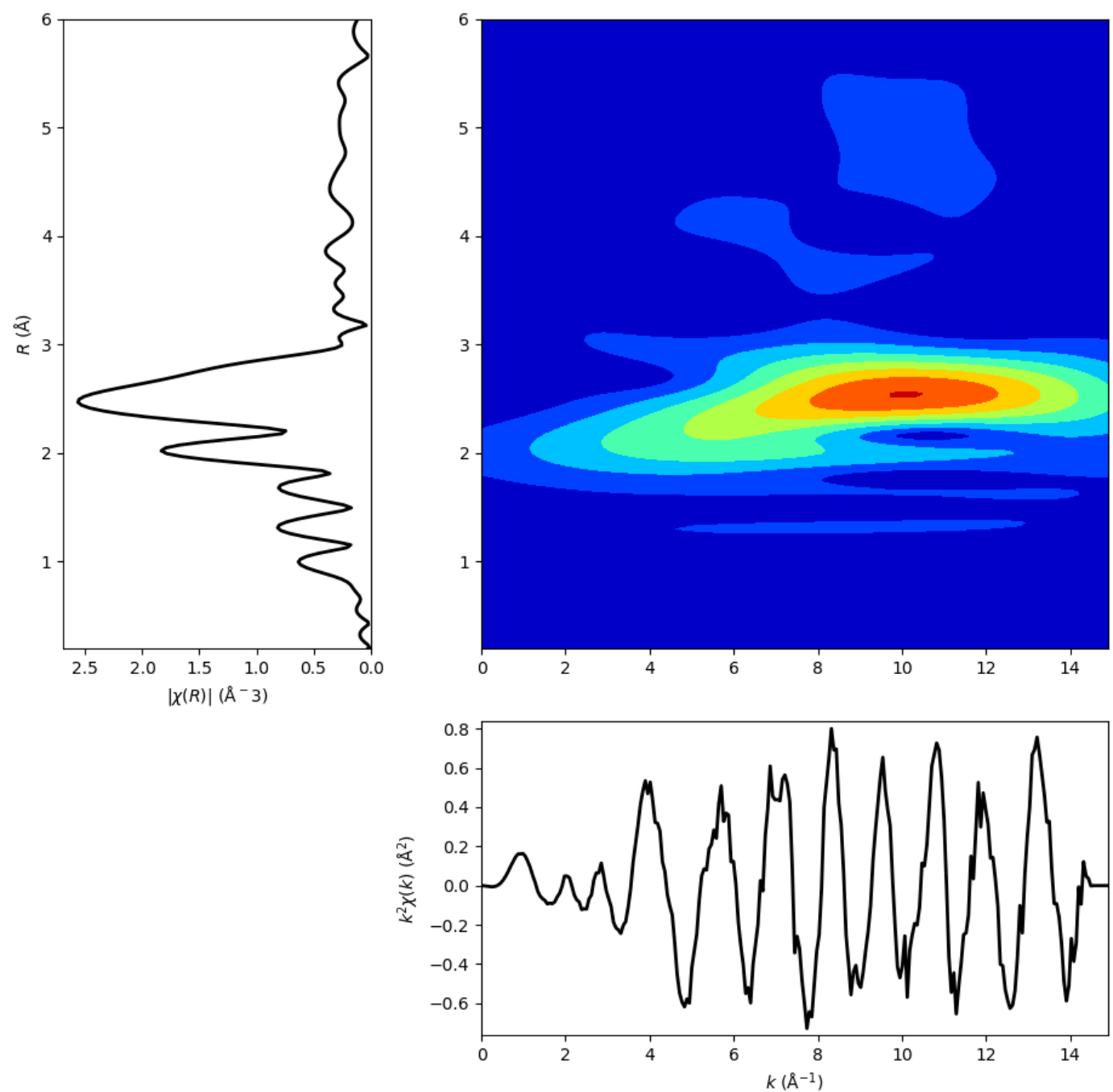

Figure S18. CCWT map of the Ir $\mathrm{L}_{\| I}$-edge EXAFS characterizing the post-TPR structure of $\mathrm{SiO}_{2}$-supported $\operatorname{Ir}\left(\mathrm{C}_{2} \mathrm{H}_{4}\right)_{2}$ complex. Spectra were obtained with the sample in flowing helium $\left(20 \mathrm{ml} / \mathrm{min}\right.$ ) at room temperature after a temperature ramp to $120^{\circ} \mathrm{C}$ with the sample in flowing $\mathrm{H}_{2}$. 

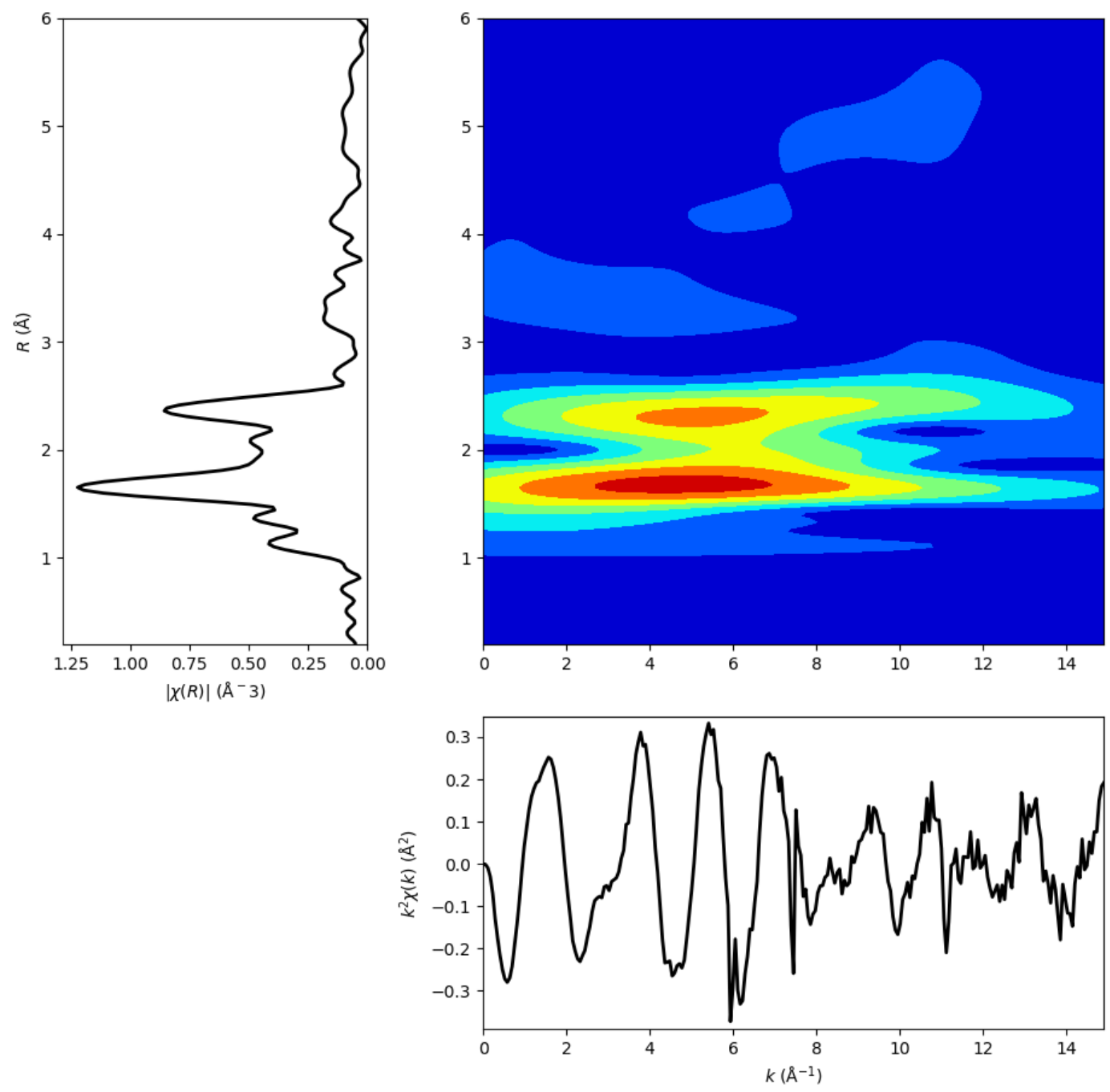

Figure S19. CCWT map of the Ir $\mathrm{L}_{\| 1}$-edge EXAFS characterizing the post-TPR structure of $\gamma$ $\mathrm{Al}_{2} \mathrm{O}_{3}$-supported $\operatorname{Ir}\left(\mathrm{C}_{2} \mathrm{H}_{4}\right)_{2}$ complex. Spectra were obtained with the sample in flowing helium $(20 \mathrm{ml} / \mathrm{min})$ at room temperature after a temperature ramp to $120^{\circ} \mathrm{C}$ with the sample in flowing $\mathrm{H}_{2}$. 

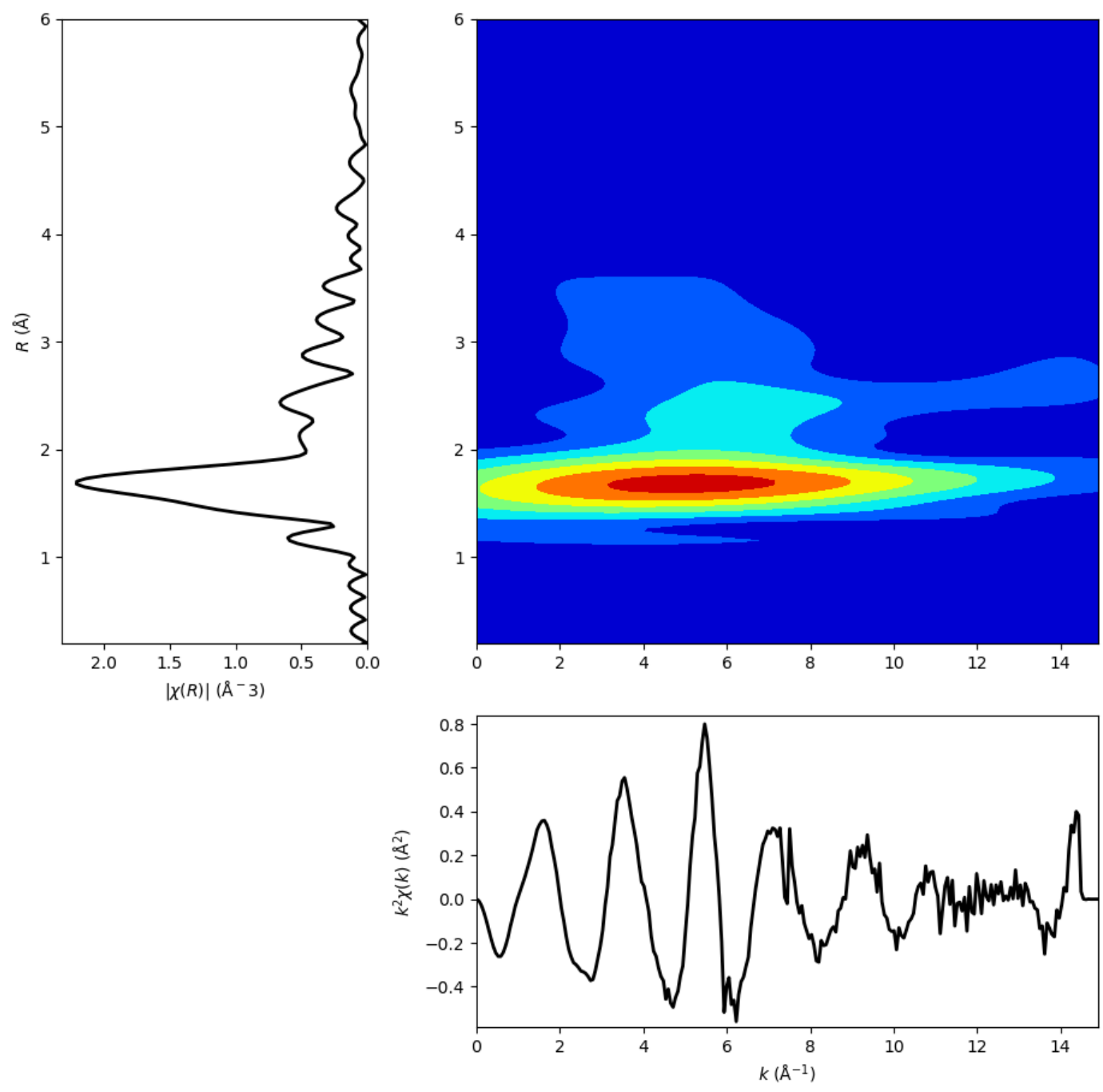

Figure S20. CCWT map of the Ir $\mathrm{L}_{111}$-edge EXAFS characterizing the post-TPR structure of $\mathrm{MgO}$-supported $\operatorname{Ir}\left(\mathrm{C}_{2} \mathrm{H}_{4}\right)_{2}$ complex. Spectra were obtained with the sample in flowing helium $(20 \mathrm{ml} / \mathrm{min})$ at room temperature after a temperature ramp to $120^{\circ} \mathrm{C}$ with the sample in flowing $\mathrm{H}_{2}$.

Table S6 presents the best-fit models characterizing the post-TPR samples obtained by using XDAP. The best-fit EXAFS model characterizing the post-TPR $\mathrm{SiO}_{2}$-supported $\operatorname{Ir}\left(\mathrm{C}_{2} \mathrm{H}_{4}\right)_{2}$ complex, given in Table S6 and Figure S21, consisted with an Ir-Ir scattering path at $2.68 \pm 0.02 \AA$ with a coordination number of $6.5 \pm 0.65$ and an $\mathrm{Ir}-\mathrm{C}$ shell at a distance of 2.40 $\AA$ with a coordination number of approximately $0.87 \pm 0.18$, possibly associated with the ligands formed by the transformation of $\pi$-bonded $\mathrm{C}_{2} \mathrm{H}_{4}$ ligands initially present on iridium during the TPR run (Table S6). These contributions correspond to the features at approximately 2.5 and $2 \AA$, respectively, in the non-corrected $R$-space data presented in Figure $\mathrm{S} 17$ (red) and Figure S21b. The proposed model obtained with XDAP represents Ir nanoparticles formed by Ir aggregation during the TPR treatment on $\operatorname{Ir}\left(\mathrm{C}_{2} \mathrm{H}_{4}\right)_{2} / \mathrm{SiO}_{2}$. This $\mathrm{Ir}-\mathrm{Ir}$ scattering path is clearly identified in the wavelet transform, Figure S18, as the feature in the $k$-range of $7-14 \AA^{-1}$ and the $R$-range of $2.3-3.0 \AA$, centered at $k=10 \AA^{-1}$ and $R=2.5 \AA$. 
Similarly, data presented in Figure $2 b$ demonstrate the growing in of a feature at approximately $2.4 \AA$ with a gradual decline of the $\mathrm{Ir}-\mathrm{C}$ and $\mathrm{Ir}-\mathrm{O}$ contributions (data not phaseand amplitude-corrected) during the temperature ramp of $\operatorname{Ir}\left(\mathrm{C}_{2} \mathrm{H}_{4}\right)_{2} / \gamma-\mathrm{Al}_{2} \mathrm{O}_{3}$ to $120^{\circ} \mathrm{C}$ in flowing $\mathrm{H}_{2}$. The post-TPR EXAFS data of this sample are shown in detail in Figure $\mathrm{S} 17$ (blue) and Figure S22 and in Table S6. The position of this new feature formed at approximately $2.4 \AA$ in the non-corrected $R$-space data match very well with the expected position of an Ir-Ir coordination in a small Ir cluster consisting of only a few Ir atoms. ${ }^{13}$ Moreover, analyzing the data at higher $k$-weightings indicates an increase in the intensity of this feature, further confirming that it is associated with an Ir-high-Z-scatterer contribution formed at the end of the TPR of $\operatorname{Ir}\left(\mathrm{C}_{2} \mathrm{H}_{4}\right)_{2} / \gamma-\mathrm{Al}_{2} \mathrm{O}_{3}$. Consistently, the best fit model characterizing the post-TPR $\gamma-\mathrm{Al}_{2} \mathrm{O}_{3}-$ supported $\operatorname{Ir}\left(\mathrm{C}_{2} \mathrm{H}_{4}\right)_{2}$ complex indicates the presence of an $\mathrm{Ir}-\mathrm{Ir}$ scattering path at $2.75 \pm 0.02 \AA$ with a coordination number of $3.7 \pm 0.4$ (Table S6).

However, this Ir-Ir scattering path is not readily apparent in the spectrum of post-TPR $\operatorname{Ir}\left(\mathrm{C}_{2} \mathrm{H}_{4}\right)_{2} / \mathrm{MgO}$ (Figure S23). This result suggests that there is no clear Ir-Ir coordination evident in the data characterizing the MgO-supported $\operatorname{Ir}\left(\mathrm{C}_{2} \mathrm{H}_{4}\right)_{2}$, and thus there is an absence of agglomeration following the TPR.

Table S6. Summary of best-fit EXAFS models of the post-TPR structures of $\mathrm{SiO}_{2^{-}}, \gamma-\mathrm{Al}_{2} \mathrm{O}_{3^{-}}$, and $\mathrm{MgO}$-supported complexes obtained using XDAP. Data were obtained with the sample in flowing helium $(20 \mathrm{ml} / \mathrm{min})$ at room temperature after a temperature ramp to $120^{\circ} \mathrm{C}$ with the sample in flowing $\mathrm{H}_{2}$.

\begin{tabular}{|c|c|c|c|c|c|c|c|}
\hline $\begin{array}{l}\text { Initial Sample } \\
\text { for TPR }\end{array}$ & $\begin{array}{l}\text { Absorber- } \\
\text { scatterer } \\
\text { path }^{\mathrm{a}}\end{array}$ & C.N. ${ }^{a}$ & $\begin{array}{c}10^{3} \times \sigma^{2 b} \\
\left(\AA^{2}\right)\end{array}$ & $\begin{array}{l}R^{\mathrm{c}} \\
(\AA)\end{array}$ & $\begin{array}{l}\Delta E_{0}{ }^{\mathrm{d}} \\
(\mathrm{eV})\end{array}$ & $\begin{array}{c}\text { k-range } \\
\left(\AA^{-1}\right)\end{array}$ & $\begin{array}{c}R \text {-range } \\
(\AA)\end{array}$ \\
\hline \multirow[t]{2}{*}{$\operatorname{Ir}\left(\mathrm{C}_{2} \mathrm{H}_{4}\right)_{2} / \mathrm{SiO}_{2}$} & Ir-Ir & 6.49 & 6.9 & 2.68 & -3.08 & $3.0-14.15$ & $1.0-3.2$ \\
\hline & $\mathrm{Ir}-\mathrm{C}$ & 0.87 & 3.0 & 2.40 & -4.85 & & \\
\hline \multirow[t]{3}{*}{$\operatorname{lr}\left(\mathrm{C}_{2} \mathrm{H}_{4}\right)_{2} / \gamma-\mathrm{Al}_{2} \mathrm{O}_{3}$} & Ir-Ir & 3.66 & 13.4 & 2.75 & -2.93 & $3.55-12.0$ & $1.0-3.5$ \\
\hline & $\mathrm{Ir}-\mathrm{C}$ & 1.00 & 4.0 & 2.15 & -7.75 & & \\
\hline & $\mathrm{Ir}-\mathrm{C}_{\mathrm{L}}$ & 1.13 & 0.3 & 3.33 & -8.23 & & \\
\hline \multirow[t]{2}{*}{$\operatorname{Ir}\left(\mathrm{C}_{2} \mathrm{H}_{4}\right)_{2} / \mathrm{MgO}$} & $\mathrm{Ir}-\mathrm{O}$ & 2.19 & 1.5 & 2.06 & 1.85 & $3.05-11.35$ & $1.0-2.1$ \\
\hline & $\mathrm{Ir}-\mathrm{C}$ & 2.19 & 4.9 & 1.96 & -8.0 & & \\
\hline
\end{tabular}

${ }^{\mathrm{a} C o o r d i n a t i o n}$ number, ${ }^{\mathrm{b}}$ disorder in neighbor distance, ${ }^{\mathrm{c}}$ absorber-scatterer distance, ${ }^{\mathrm{d} e n e r g y}$ shift. Numbers in parentheses are the estimated errors. The accuracies of the parameters obtained by XDAP fitting are estimated to be as follows: coordination number $N, \pm 20 \%$ for Ir-low-Z scatterer contributions, $\pm 10 \%$ for Ir-high-Z scatterer contributions; distance $R, \pm 0.02 \AA$; disorder term $\Delta \sigma^{2}, \pm 20 \%$; and inner potential correction $\Delta E_{0}, \pm 20 .{ }^{13} \mathrm{~L}$ in $\operatorname{Ir}-\mathrm{C}_{\mathrm{L}}$ stands for a long-distance $C$ neighbor. 

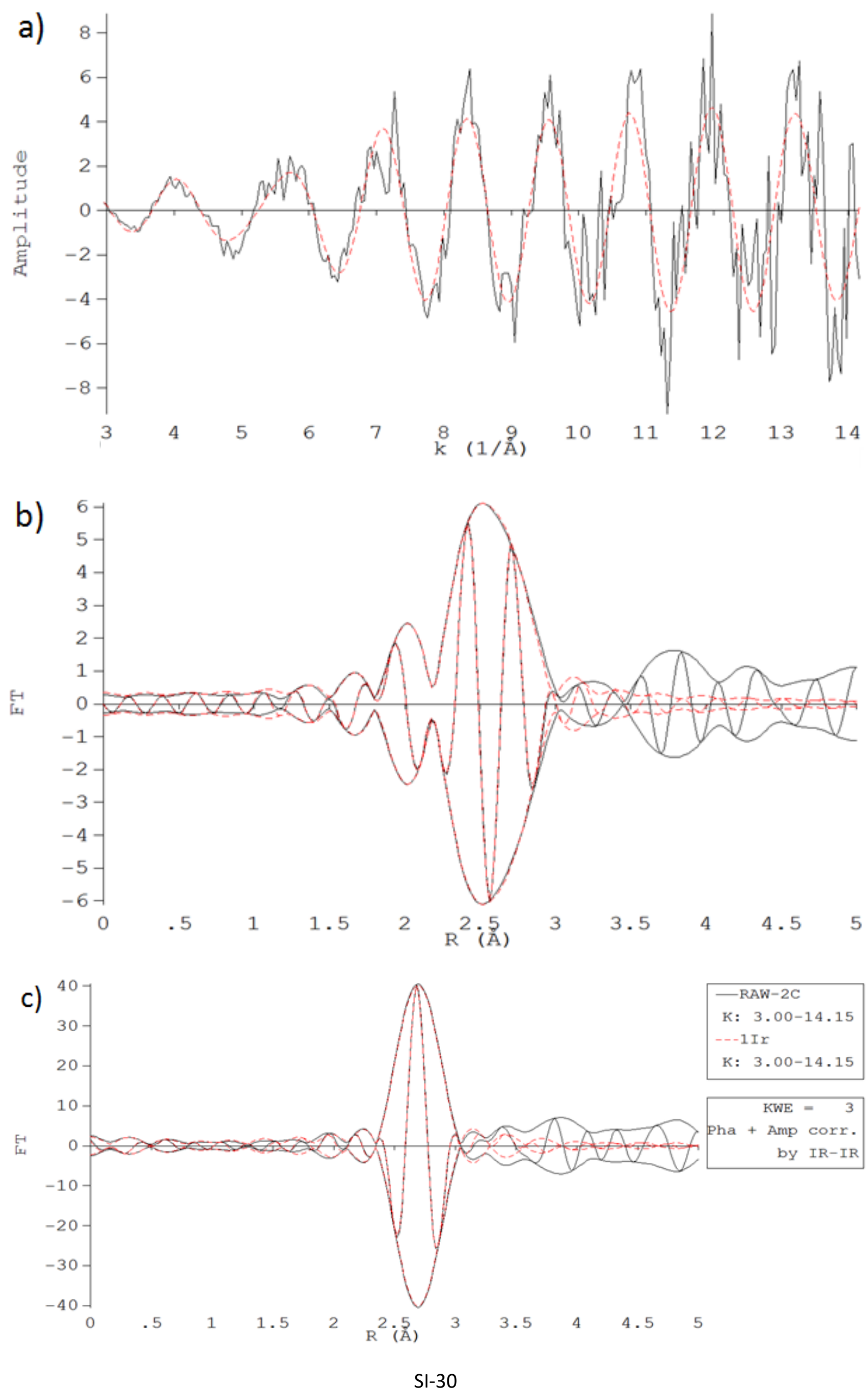


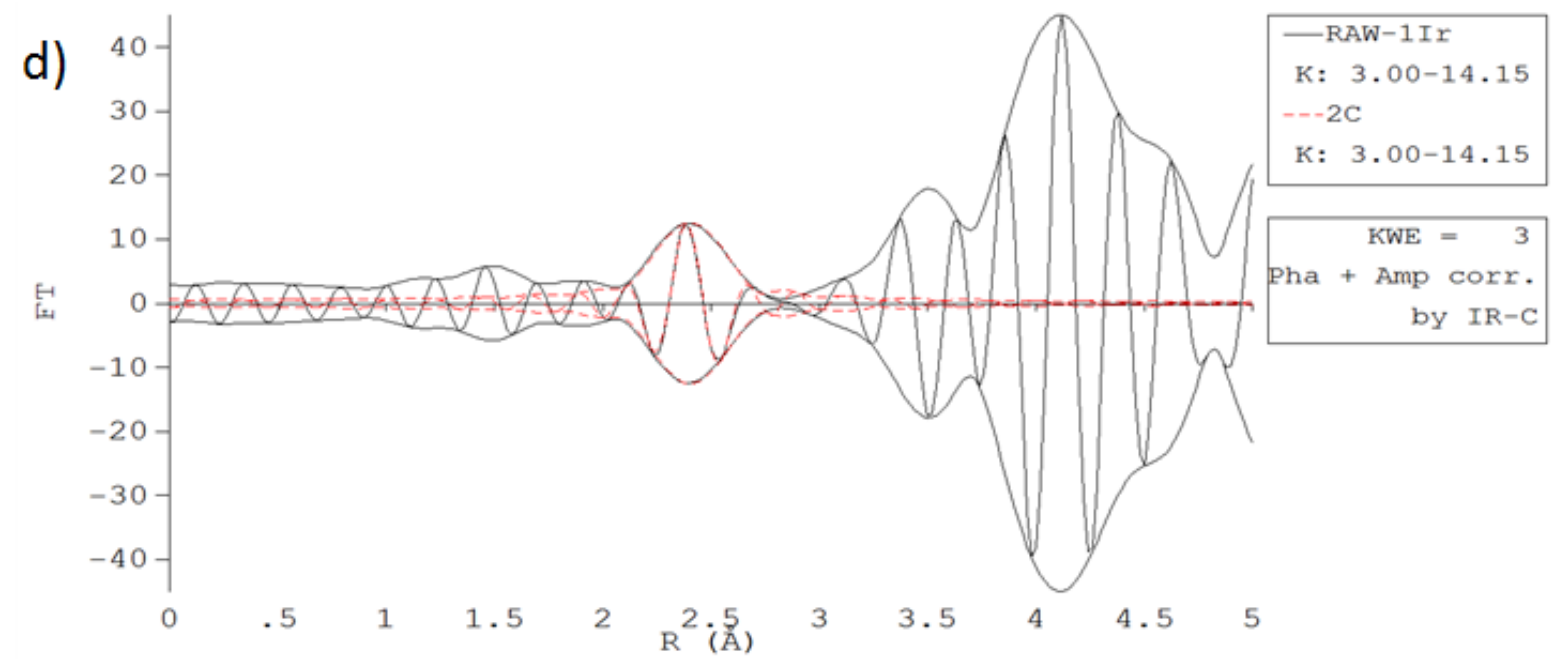

Figure S21. Results of EXAFS analysis by XDAP characterizing the post-TPR structure of $\mathrm{SiO}_{2}$-supported $\operatorname{Ir}\left(\mathrm{C}_{2} \mathrm{H}_{4}\right)_{2}$ complex. a) $k^{3}$-weighted EXAFS function, $\chi$, (solid line), and calculated contribution (dotted line), b) $k^{3}$-weighted imaginary part and magnitude of the Fourier-transform of data (solid line), and calculated contribution (dotted line), c) $k^{3}$-weighted imaginary part and magnitude of phase- and amplitude-corrected Fourier transform of data minus Ir-C contribution (solid line) and calculated Ir-Ir contribution (dotted line), d) $k^{3}$-weighted imaginary part and magnitude of phase- and amplitude-corrected Fourier transform of data minus Ir-Ir contribution (solid line) and calculated Ir-C contribution (dotted line). Data were collected with the sample in flowing helium $(20 \mathrm{ml} / \mathrm{min})$ at room temperature after a temperature ramp to $120^{\circ} \mathrm{C}$ with the sample in flowing $\mathrm{H}_{2}$. 

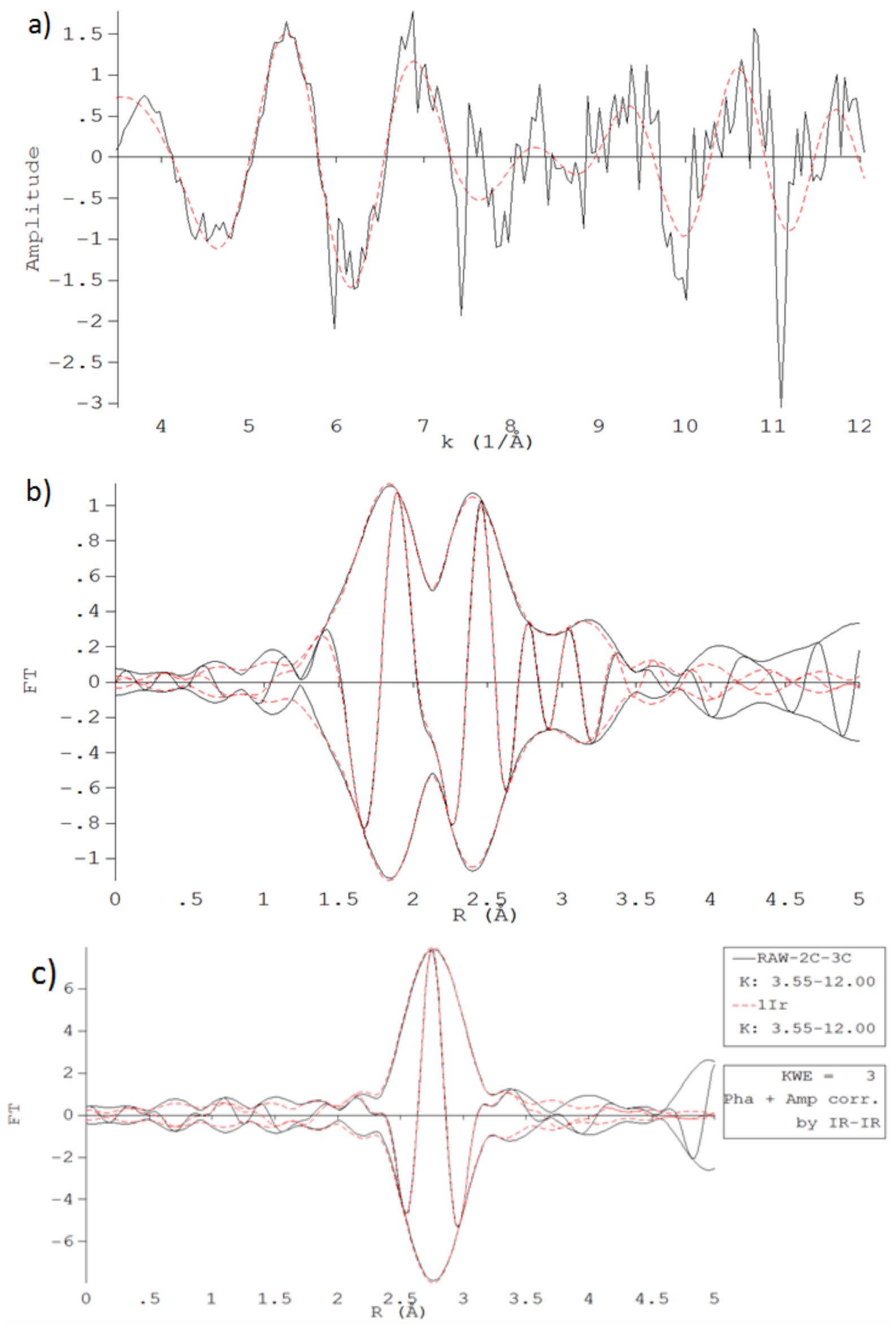

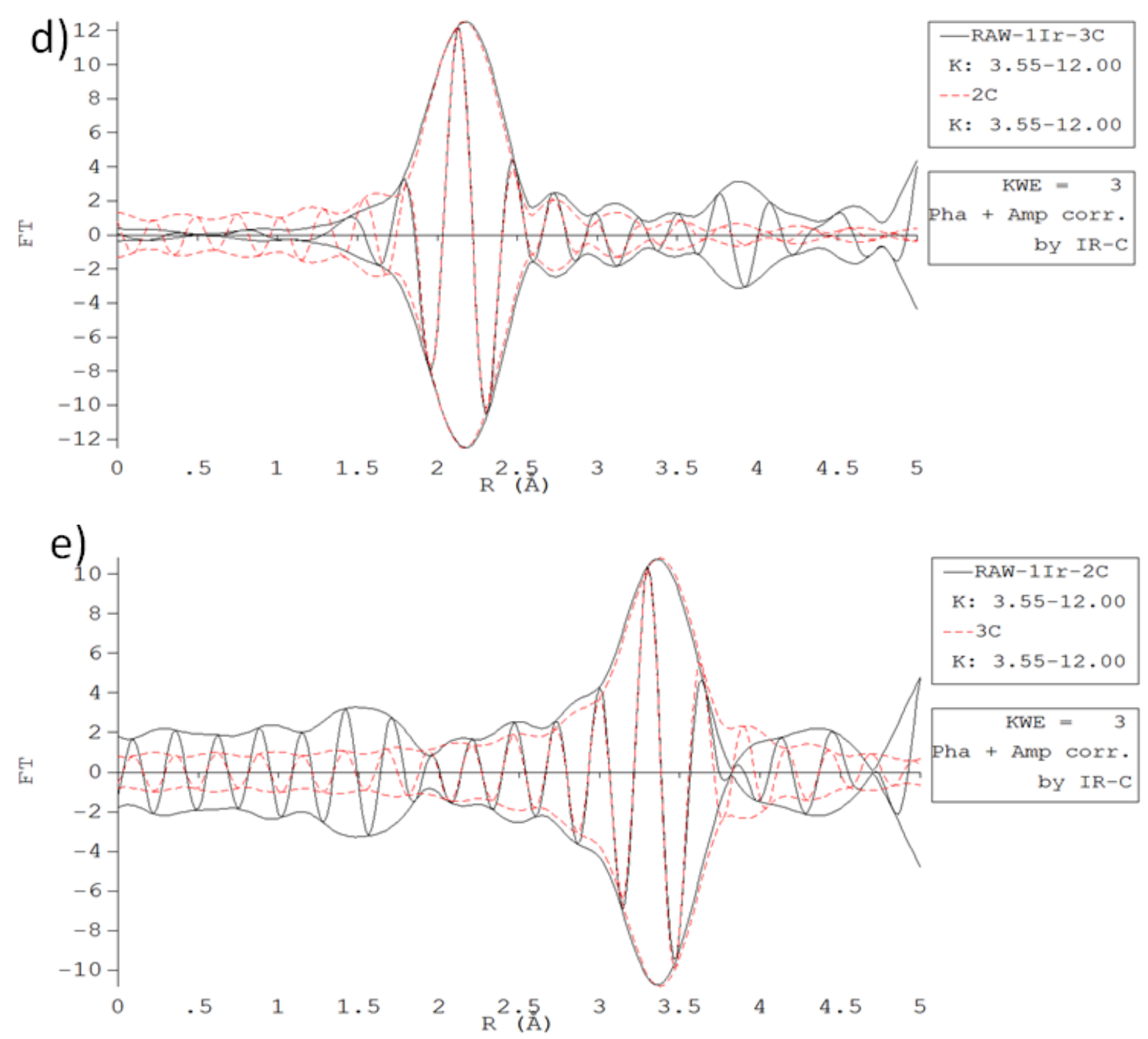

Figure S22. Results of EXAFS analysis by XDAP characterizing the post-TPR structure of $\gamma$ $\mathrm{Al}_{2} \mathrm{O}_{3}$-supported $\operatorname{Ir}\left(\mathrm{C}_{2} \mathrm{H}_{4}\right)_{2}$ complex: a) $k^{3}$-weighted EXAFS function, $\chi$, (solid line), and calculated contribution (dotted line), b) $k^{3}$-weighted imaginary part and magnitude of the Fourier-transform of data (solid line), and calculated contribution (dotted line), c) $k^{3}$-weighted imaginary part and magnitude of phase- and amplitude-corrected Fourier transform of data minus Ir-C and Ir $-C_{L}$ (where $L$ stands for a long-distance $C$ neighbor; this shell might be associated with the ligands formed by the conversion of $\pi$-bonded $\mathrm{C}_{2} \mathrm{H}_{4}$ ligands during the TPR run) contribution (solid line) and calculated Ir-Ir contribution (dotted line), d) $k^{3}$-weighted imaginary part and magnitude of phase- and amplitude-corrected Fourier transform of data minus Ir-Ir and Ir $-\mathrm{C}_{\llcorner}$contribution (solid line) and calculated Ir-C contribution (dotted line), e) $k^{3}$-weighted imaginary part and magnitude of phase- and amplitude-corrected Fourier transform of data minus $\mathrm{Ir}-\mathrm{C}$ and $\mathrm{Ir}-\mathrm{Ir}$ contribution (solid line) and calculated $\mathrm{Ir}-\mathrm{C}_{\llcorner}$contribution (dotted line). Data were collected with the sample in flowing helium $(20 \mathrm{ml} / \mathrm{min})$ at room temperature after a temperature ramp to $120^{\circ} \mathrm{C}$ with the sample in flowing $\mathrm{H}_{2}$. 

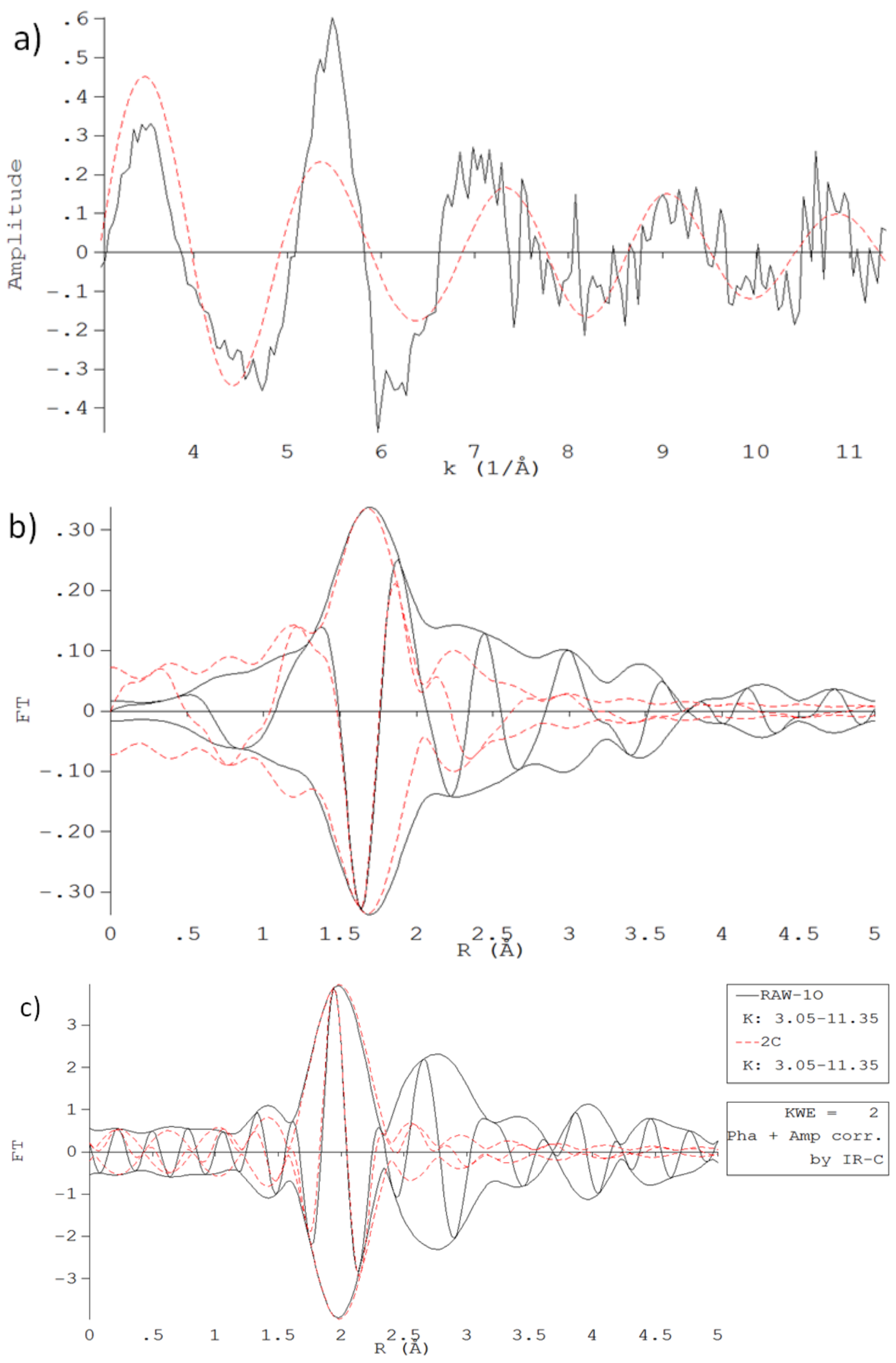


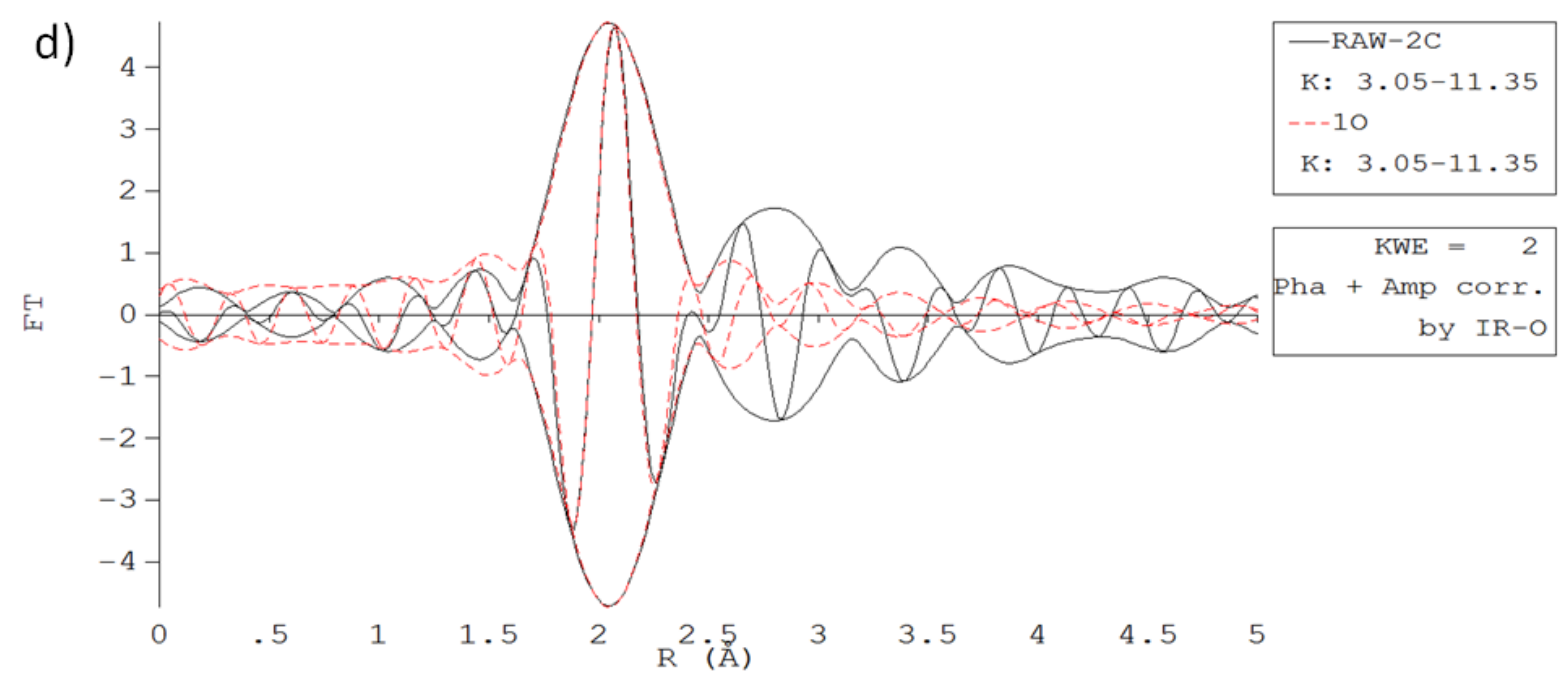

Figure S23. Results of EXAFS analysis by XDAP characterizing the post-TPR structure of MgO-supported $\operatorname{Ir}\left(\mathrm{C}_{2} \mathrm{H}_{4}\right)_{2}$ complex. a) $k^{2}$-weighted EXAFS function, $\chi$, (solid line), and calculated contribution (dotted line), b) $k^{2}$-weighted imaginary part and magnitude of the Fourier-transform of data (solid line), and calculated contribution (dotted line), c) $k^{2}$-weighted imaginary part and magnitude of phase- and amplitude-corrected Fourier transform of data minus Ir-C contribution (solid line) and calculated Ir-O contribution (dotted line), d) $k^{2}$-weighted imaginary part and magnitude of phase- and amplitude-corrected Fourier transform of data minus Ir-O contribution (solid line) and calculated Ir-C contribution (dotted line), Data were collected with the sample in flowing helium $(20 \mathrm{ml} / \mathrm{min})$ at room temperature after a temperature ramp to $120^{\circ} \mathrm{C}$ with the sample in flowing $\mathrm{H}_{2}$.

\section{S2.9. Surface densities of as-prepared supported Ir complexes}

Table S7 represents the calculated average diameter of the nanoparticles (clusters) formed on the post-TPR structure of $\mathrm{SiO}_{2}$-supported $\operatorname{Ir}\left(\mathrm{C}_{2} \mathrm{H}_{4}\right)_{2}$. The diameter of the iridium cluster formed at the end of the TPR treatment of the $\mathrm{SiO}_{2}$-supported $\operatorname{Ir}\left(\mathrm{C}_{2} \mathrm{H}_{4}\right)_{2}$ was determined to be $0.7 \mathrm{~nm}$ (Table S7) based on the corresponding Ir-Ir coordination number in Table S6 (6.49) and assuming an icosahedral structure. ${ }^{34-35}$ Data align well with previous results reporting cluster formation upon treating supported complexes at high temperatures with the sample in flowing $\mathrm{H}_{2}$. For instance, Aydin et al. showed that a MgO-supported $\operatorname{Ir}\left(\mathrm{C}_{2} \mathrm{H}_{4}\right)_{2}$ complex undergoes aggregation with the sample in flowing $\mathrm{H}_{2}$ at $400{ }^{\circ} \mathrm{C}$, which results in a particle diameter of $1.04 \mathrm{~nm}$ determined both by EXAFS and by STEM imaging. ${ }^{36}$ Moreover, MgO-, $\gamma-\mathrm{Al}_{2} \mathrm{O}_{3^{-}}$, and $\mathrm{SiO}_{2}$-supported $\operatorname{Ir}(\mathrm{CO})_{2}$ complexes treated with the sample in flowing $\mathrm{H}_{2}$ flow at $400{ }^{\circ} \mathrm{C}$ for $1 \mathrm{~h}$ resulted in the formation of nanoclusters with average diameters of 1.1 $\pm 0.4,1.2 \pm 0.3$, and $1.5 \pm 0.4 \mathrm{~nm}$, respectively. ${ }^{37}$ The $\mathrm{Ir}-\mathrm{Ir}$ coordination number of approximately 3 for the data characterizing post-TPR structure of the $\gamma-\mathrm{Al}_{2} \mathrm{O}_{3}$-supported $\operatorname{Ir}\left(\mathrm{C}_{2} \mathrm{H}_{4}\right)_{2}$ complex $(3.66 \pm 0.37$, Table $\mathrm{S} 6)$ points to the presence of small Ir clusters, approximated as $\operatorname{Ir}_{4}$ clusters. Consistent with earlier reports, it was determined that the $\operatorname{Ir}\left(\mathrm{C}_{2} \mathrm{H}_{4}\right)_{2}$ complexes supported on dealuminated zeolite $\mathrm{Y}$, located preferentially near the $\mathrm{Al}$ sites of the zeolite, formed stable $\mathrm{Ir}_{4}$ clusters during a temperature ramp to $80{ }^{\circ} \mathrm{C}$ with the sample in flowing $\mathrm{H}_{2 .}{ }^{5,11}$ On the basis of previous reports providing STEM images of $\mathrm{Ir}_{4}$ clusters formed on DAY zeolite and on $\mathrm{MgO},{ }^{25,31}$ the diameter of the $\mathrm{Ir}_{4}$ clusters formed from $\gamma-\mathrm{Al}_{2} \mathrm{O}_{3^{-}}$ supported $\operatorname{Ir}\left(\mathrm{C}_{2} \mathrm{H}_{4}\right)_{2}$ was estimated to be $0.6 \mathrm{~nm}$ (Table S7). 
Table S7. Surface areas of $\mathrm{SiO}_{2}, \gamma-\mathrm{Al}_{2} \mathrm{O}_{3}$, and $\mathrm{MgO}$, surface densities of supported iridium complexes on each support in the as-prepared samples, and average diameters of iridium clusters formed after TPR.

\begin{tabular}{lccc}
\hline Sample & $\begin{array}{c}\text { Surface area of } \\
\text { support }\left(\mathbf{m}^{2} / \mathbf{g}\right)\end{array}$ & $\begin{array}{c}\text { Surface density of } \mathbf{~ r} \\
\text { in as-prepared } \\
\text { sample }(\text { atom/nm }\end{array}$ & $\begin{array}{c}\text { Diameter of } \\
\text { formed cluster } \\
\text { post-TPR }(\mathbf{n m})\end{array}$ \\
\hline $\operatorname{Ir}\left(\mathrm{C}_{2} \mathrm{H}_{4}\right)_{2} / \mathrm{SiO}_{2}$ & 331 & 0.096 & $0.7^{\mathrm{a}}$ \\
$\operatorname{Ir}\left(\mathrm{C}_{2} \mathrm{H}_{4}\right)_{2} / \gamma-\mathrm{Al}_{2} \mathrm{O}_{3}$ & 185 & 0.171 & $0.6^{\mathrm{b}}$ \\
$\operatorname{Ir}\left(\mathrm{C}_{2} \mathrm{H}_{4}\right)_{2} / \mathrm{MgO}$ & 33 & 0.959 & - $^{\mathrm{c}}$ \\
\hline
\end{tabular}

aThe diameter was calculated based on the icosahedral structure. ${ }^{\mathrm{b}}$ The diameter of $\mathrm{Ir}_{4}$ cluster was approximated based on previous reports. ${ }^{25,31} \mathrm{clt}$ was not possible to fit an Ir-Ir scattering path to the EXAFS data of the post-TPR MgO-supported sample.

\section{S2.10. Computational results: bond dissociation energies}

The bond dissociation energy is used to quantify the strength of a chemical bond, thus, it is a measure to determine the stability of the supported Ir complexes. ${ }^{38}$ For this purpose, bond dissociation energies were calculated for the $\mathrm{SiO}_{2^{-}}, \gamma-\mathrm{Al}_{2} \mathrm{O}_{3^{-}}$, and $\mathrm{MgO}$-supported $\operatorname{Ir}\left(\mathrm{C}_{2} \mathrm{H}_{4}\right)_{2}$ complexes by increasing the distance between Ir and $\mathrm{O} 0.5 \AA$ in each step starting from the structure corresponding to global minima and taking the difference between electronic energies of the initial and final structures. This procedure was carried out for $\mathrm{SiO}_{2^{-}}, \gamma-\mathrm{Al}_{2} \mathrm{O}_{3^{-}}$, and $\mathrm{MgO}$-bonded to $\operatorname{Ir}\left(\mathrm{C}_{2} \mathrm{H}_{4}\right)_{2}$, where the corresponding bond dissociation energies have been determined as $75.6,79.5$, and $98.8 \mathrm{kcal} / \mathrm{mol}$, respectively (Table S8). The bond energies show the same trend as the bond distances between Ir and the $O$ atoms on the surface (Figure S9). These findings are in good agreement with the experimental findings, whereby EXAFS data demonstrate that the iridium becomes more stable with an increase in its electron density through electron donation from the support (Figure S7, Table S6). For the $\mathrm{SiO}_{2^{-}}, \gamma-\mathrm{Al}_{2} \mathrm{O}_{3^{-}}$, and MgO-supported $\operatorname{Ir}\left(\mathrm{C}_{2} \mathrm{H}_{4}\right)_{2}$ complexes, the electronic energies for the bond dissociations are displayed in Figure S24.

Table S8. Bond dissociation energies of $\mathrm{SiO}_{2^{-}}, \gamma-\mathrm{Al}_{2} \mathrm{O}_{3^{-}}$, and $\mathrm{MgO}$-supported $\operatorname{Ir}\left(\mathrm{C}_{2} \mathrm{H}_{4}\right)_{2}$ complexes (PBE/6-31G(d,p)).

\begin{tabular}{lc}
\hline Sample & $\begin{array}{r}\text { Bond dissociation energies for dissociation of } \operatorname{Ir}\left(\mathrm{C}_{2} \mathrm{H}_{4}\right)_{2} \\
\text { complex from support's surface (kcal/mol) }\end{array}$ \\
\hline $\operatorname{Ir}\left(\mathrm{C}_{2} \mathrm{H}_{4}\right)_{2} / \mathrm{SiO}_{2}$ & 75.6 \\
$\operatorname{Ir}\left(\mathrm{C}_{2} \mathrm{H}_{4}\right)_{2} / \gamma-\mathrm{Al}_{2} \mathrm{O}_{3}$ & 79.5 \\
$\operatorname{Ir}\left(\mathrm{C}_{2} \mathrm{H}_{4}\right)_{2} / \mathrm{MgO}$ & 98.8 \\
\hline
\end{tabular}


a)

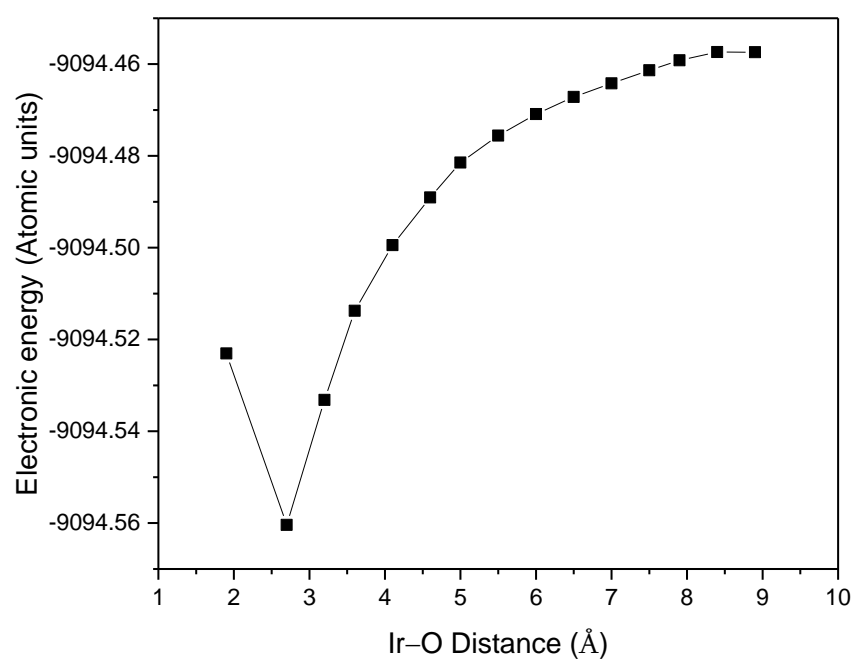

b)

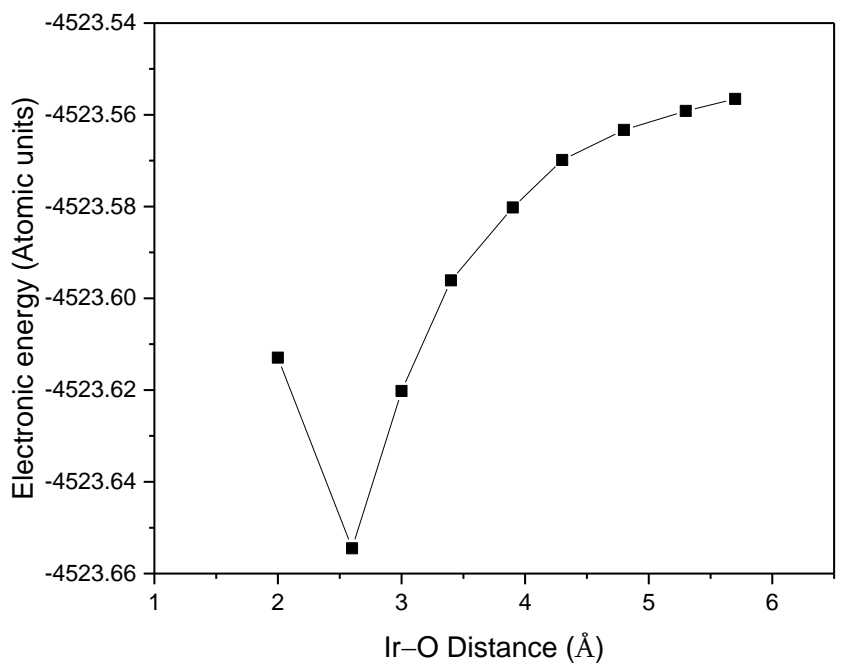

c)

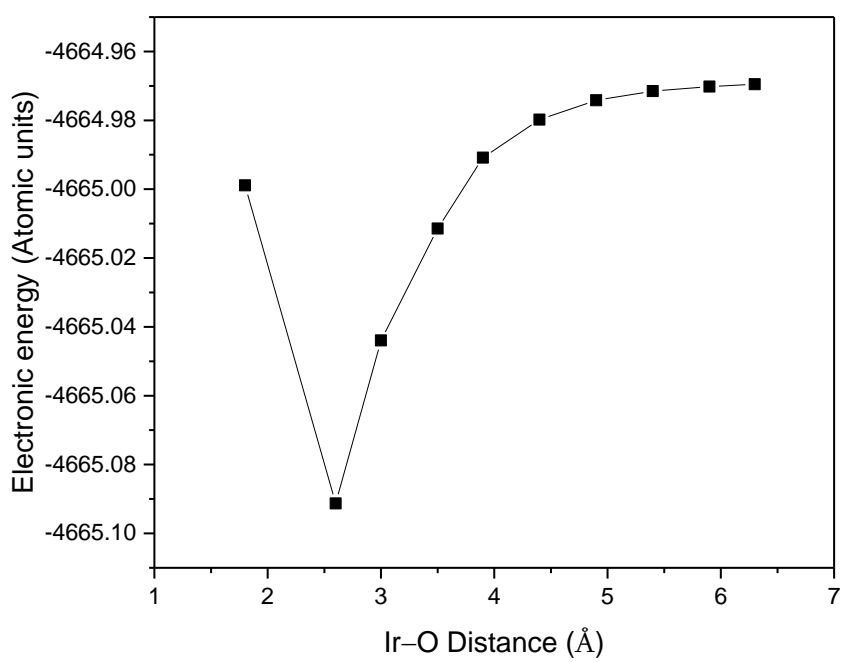

Figure S24. Electronic energies of a) $\mathrm{SiO}_{2^{-}}$, b) $\gamma-\mathrm{Al}_{2} \mathrm{O}_{3^{-}}$, and c) $\mathrm{MgO}$-supported $\operatorname{Ir}\left(\mathrm{C}_{2} \mathrm{H}_{4}\right)_{2}$ complexes obtained by step-wise increase in Ir-O distance in each model representing different supports (PBE/6-31G(d,p)). 


\subsection{EXAFS results characterizing post-TPR [EMIM][OAc]-coated $\mathrm{SiO}_{2}$-supported sample (following a temperature ramp to $120^{\circ} \mathrm{C}$ with the sample in flowing $\mathrm{H}_{2}$ )}

For the data characterizing the post-TPR structure of the [EMIM][OAc]-coated $\mathrm{SiO}_{2}-$ supported sample, the CCWT (Figure S25) as well as the EXAFS analysis (Figure S26) showed no distinguishable contribution of an Ir-Ir scattering path. Four models were considered, each of them having the same Ir-C and Ir-O scattering paths determined from the fits characterizing the as-prepared samples with three of the models including an additional Ir$\mathrm{Ir}$, Ir-Si, or Ir-long $\mathrm{C}$ scattering path. The only model that converged with coordination numbers, $\sigma^{2}$ values, and path lengths that make chemical sense was the model that included only the $\mathrm{Ir}-\mathrm{O}$ and $\mathrm{Ir}-\mathrm{C}$ paths at bonding distances (Table S9).
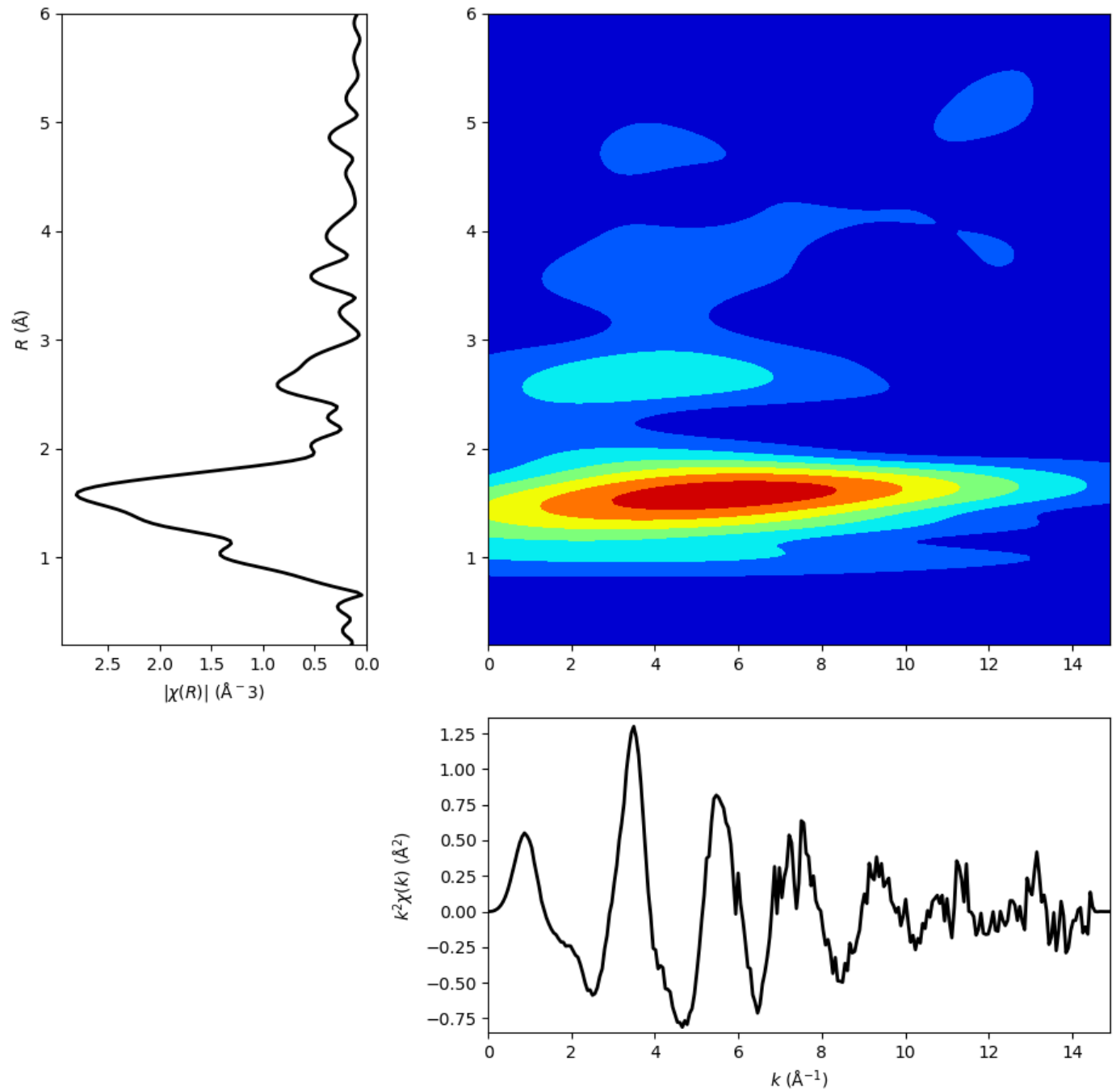

Figure S25. CCWT map of the Ir LוII-edge EXAFS data characterizing the post-TPR structure of [EMIM][OAc]-coated $\mathrm{SiO}_{2}$-supported $\operatorname{Ir}\left(\mathrm{C}_{2} \mathrm{H}_{4}\right)_{2}$ complex. Spectra were obtained with the sample in flowing helium $(20 \mathrm{ml} / \mathrm{min})$ at room temperature after a temperature ramp to $120^{\circ} \mathrm{C}$ with the sample in flowing $\mathrm{H}_{2}$. 
a)

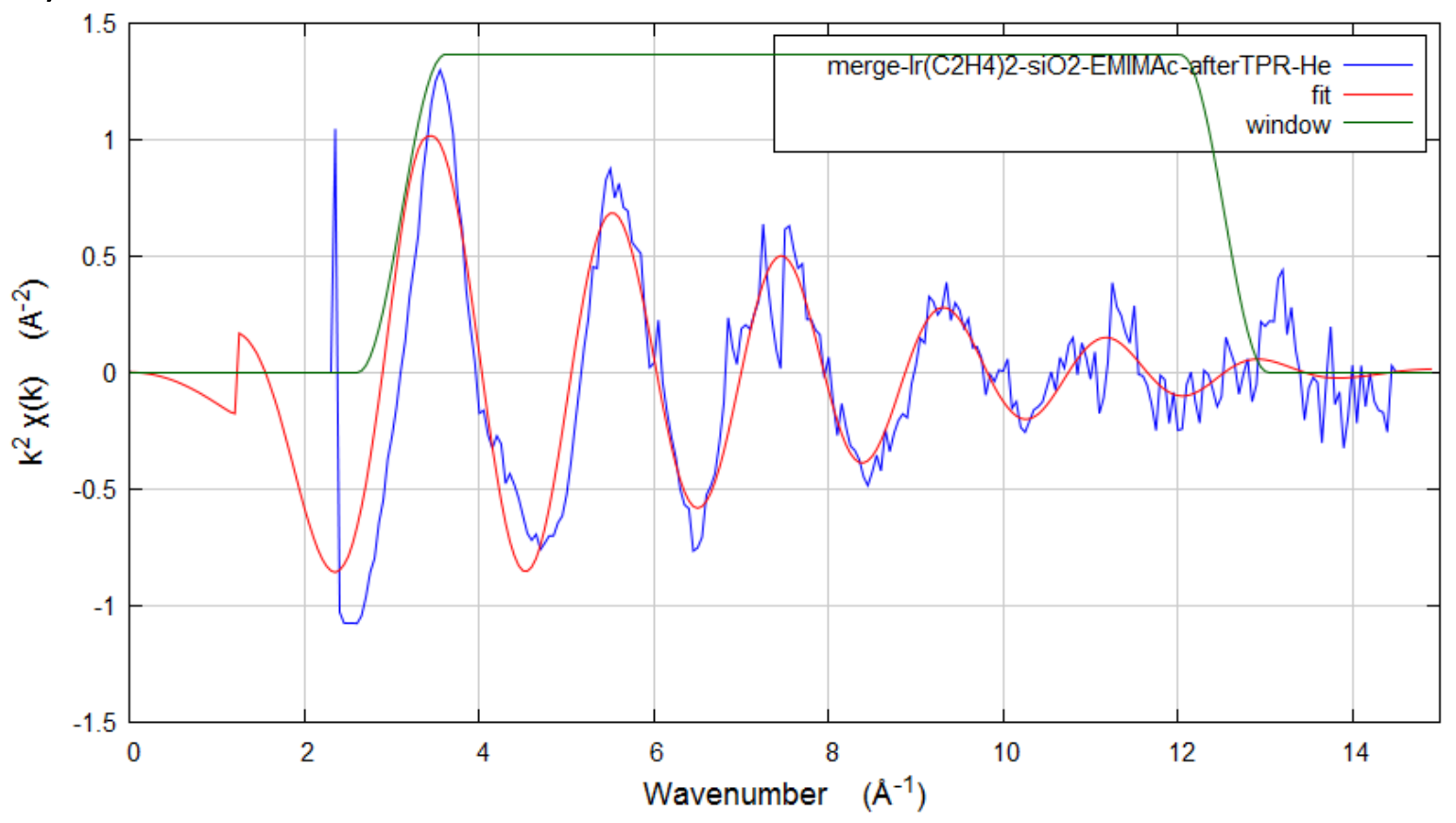

b)

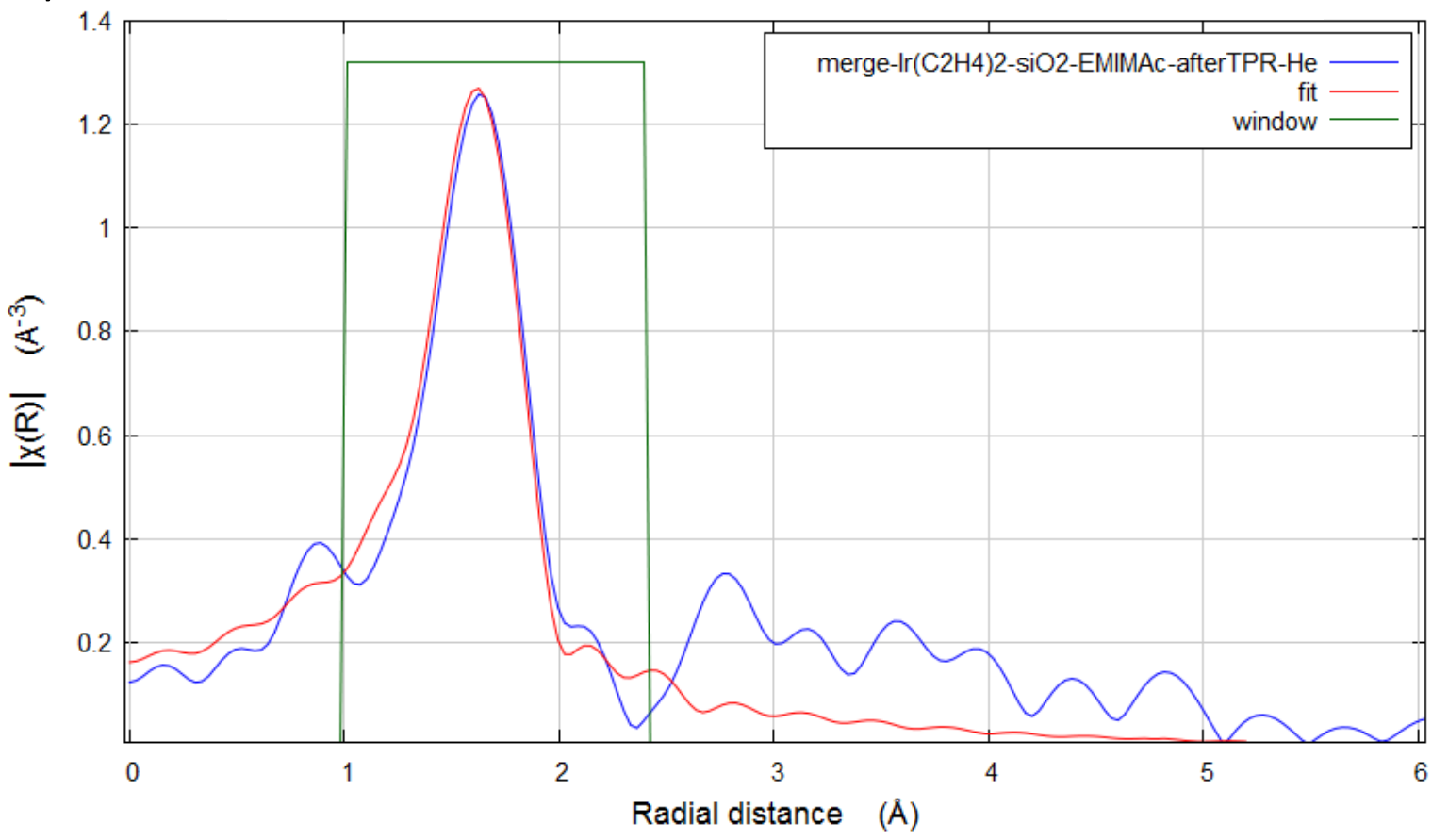



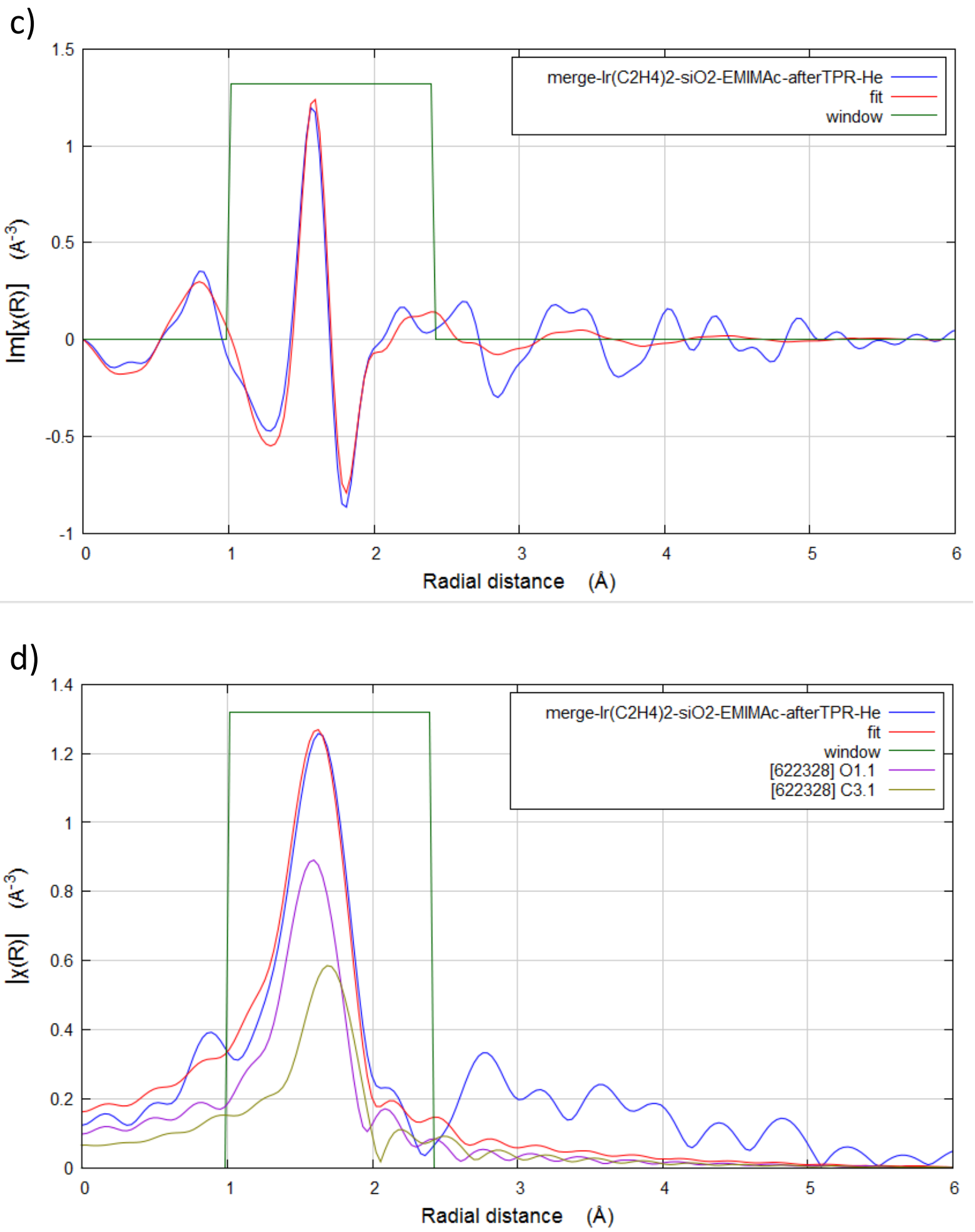


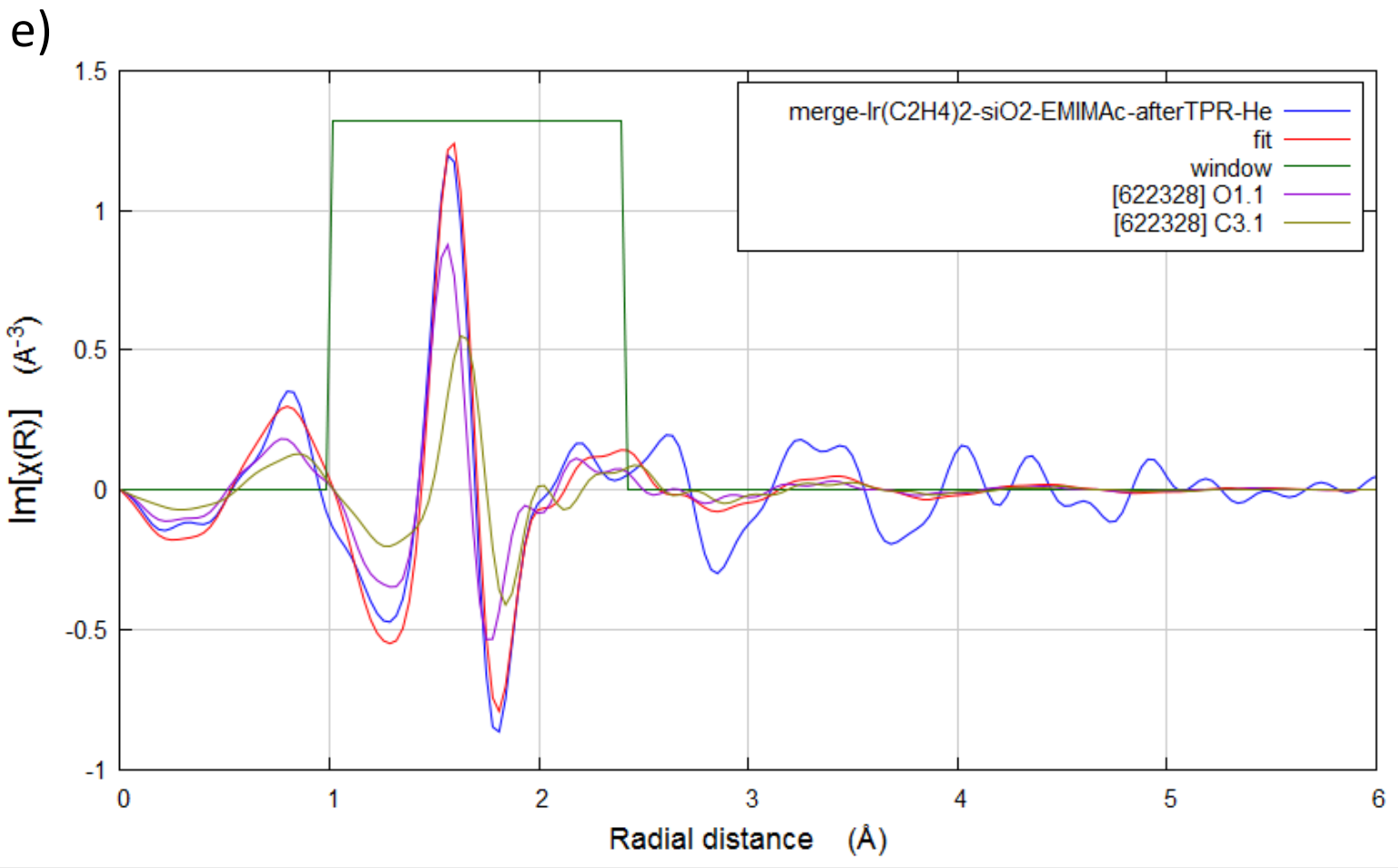

Figure S26. Results of EXAFS analysis by ARTEMIS characterizing the post-TPR structure of [EMIM] [OAc]-coated $\mathrm{SiO}_{2}$-supported $\operatorname{Ir}\left(\mathrm{C}_{2} \mathrm{H}_{4}\right)_{2}$ complex. a) $k^{2}$-weighted EXAFS and best-fit EXAFS model. (b) $k^{2}$-weighted magnitude of the Fourier-transform of the EXAFS and best fit model. (c) $k^{2}$-weighted imaginary component of the Fourier-transform of the EXAFS and best fit model. (d) $k^{2}$-weighted magnitude of the Fourier-transform of the EXAFS with the $k^{2}$ weighted EXAFS of all paths used in the model. (e) $k^{2}$-weighted imaginary component of the EXAFS with the $k^{2}$-weighted EXAFS of all paths used in the model. Data were collected with the sample in flowing helium $(20 \mathrm{ml} / \mathrm{min})$ at room temperature after a temperature ramp to 120 ${ }^{\circ} \mathrm{C}$ with the sample in flowing $\mathrm{H}_{2}$.

Table S9. Summary of best-fit EXAFS model of the post-TPR structure of [EMIM][OAc]-coated $\mathrm{SiO}_{2}$-supported $\operatorname{Ir}\left(\mathrm{C}_{2} \mathrm{H}_{4}\right)_{2}$ complex obtained using ARTEMIS. Data were obtained with the sample in flowing helium $(20 \mathrm{ml} / \mathrm{min})$ at room temperature after a temperature ramp to $120^{\circ} \mathrm{C}$ with the sample in flowing $\mathrm{H}_{2}$.

\begin{tabular}{|c|c|c|c|c|c|c|c|}
\hline $\begin{array}{l}\text { Initial Sample } \\
\text { for TPR }\end{array}$ & $\begin{array}{c}\text { Absorber } \\
\text {-scatterer } \\
\text { path }^{\mathrm{a}}\end{array}$ & C.N. ${ }^{b}$ & $\begin{array}{c}10^{3} \times \sigma^{2 c} \\
\left(\AA^{2}\right)\end{array}$ & $\begin{array}{l}R^{\mathrm{d}} \\
(\AA)\end{array}$ & $\begin{array}{l}\Delta E_{0} \mathrm{e}^{\mathrm{a}} \\
(\mathrm{eV})\end{array}$ & $\begin{array}{c}\text { k-range } \\
\left(\AA^{-1}\right)\end{array}$ & $\begin{array}{c}R \text {-range } \\
(A)\end{array}$ \\
\hline $\begin{array}{c}\text { [EMIM][OAc]- } \\
\text { coated }\end{array}$ & Ir-O & $3.0(3.3)$ & $2.7(6.8)$ & $1.99(0.06)$ & $5.5(2.6)$ & $3.1-12.5$ & $1.0-2.4$ \\
\hline $\operatorname{lr}\left(\mathrm{C}_{2} \mathrm{H}_{4}\right)_{2} / \mathrm{SiO}_{2}$ & $\mathrm{Ir}-\mathrm{C}$ & $3.2(4.4)$ & $2.3(6.8)$ & $2.12(0.06)$ & $5.5(2.6)$ & & \\
\hline
\end{tabular}




\section{References}

(1) Bhirud, V. A.; Uzun, A.; Kletnieks, P. W.; Craciun, R.; Haw, J. F.; Dixon, D. A.; Olmstead, M. M.; Gates, B. C. Synthesis and crystal structure of $\operatorname{Ir}\left(\mathrm{C}_{2} \mathrm{H}_{4}\right)_{2}\left(\mathrm{C}_{5} \mathrm{H}_{7} \mathrm{O}_{2}\right)$. J. Organomet. Chem. 2007, 692, 2107-2113.

(2) Hoffman, A. S.; Singh, J. A.; Bent, S. F.; Bare, S. R. In situ observation of phase changes of a silica-supported cobalt catalyst for the Fischer-Tropsch process by the development of a synchrotron-compatible in situ/operando powder X-ray diffraction cell. J. Synchrotron Radiat. 2018, 25, 1673-1682.

(3) Ravel, B.; Newville, M. ATHENA, ARTEMIS, HEPHAESTUS: data analysis for X-ray absorption spectroscopy using IFEFFIT. J. synchrotron Radiat. 2005, 12, 537-541.

(4) Vaarkamp, M.; Linders, J. C.; Koningsberger, D. C. A new method for parameterization of phase shift and backscattering amplitude. Physica B: Condens. Matter 1995, 208, 159-160.

(5) Uzun, A.; Bhirud, V. A.; Kletnieks, P. W.; Haw, J. F.; Gates, B. C. A site-isolated iridium diethylene complex supported on highly dealuminated $\mathrm{Y}$ zeolite: Synthesis and characterization. J. Phys. Chem. C 2007, 111, 15064-15073.

(6) Uzun, A.; Gates, B. C. Real-time characterization of formation and breakup of iridium clusters in highly dealuminated zeolite Y. Angew. Chem. Int. Ed. 2008, 47, 9245-9248.

(7) Zabinsky, S. I.; Rehr, J. J.; Ankudinov, A.; Albers, R. C.; Eller, M. J. Multiple-scattering calculations of x-ray-absorption spectra. Phys. Rev. B 1995, 52, 2995-3009.

(8) Guzman, J.; Gates, B. C. A mononuclear gold complex catalyst supported on MgO: spectroscopic characterization during ethylene hydrogenation catalysis. J. Catal. 2004, 226, 111-119.

(9) Koningsberger, D.; Mojet, B.; Van Dorssen, G.; Ramaker, D. XAFS spectroscopy; fundamental principles and data analysis. Top. Catal. 2000, 10, 143-155.

(10) Zon, J. B. A. D. v.; Koningsberger, D. C.; Blik, H. F. J. v. t.; Sayers, D. E. An EXAFS study of the structure of the metal-support interface in highly dispersed $\mathrm{Rh} / \mathrm{Al}_{2} \mathrm{O}_{3}$ catalysts. J. Chem. Phys. 1985, 82, 5742-5754.

(11) Kirlin, P. S.; Van Zon, F. B. M.; Koningsberger, D. C.; Gates, B. C. Surface Catalytic Sites Prepared from $\left[\mathrm{HRe}(\mathrm{CO})_{5}\right]$ and $\left[\mathrm{H}_{3} \mathrm{Re}_{3}(\mathrm{CO})_{12}\right]$ : Mononuclear, Trinuclear, and Metallic Rhenium Catalysts Supported on MgO. J. Phys. Chem. 1990, 94, 8439-8450.

(12) Villars, P.; Calvert, L. Pearson's Handbook of Crystallographic Data for Intermediate Phases. American Society of Metals, Cleveland, $\mathrm{OH} 1985$.

(13) Uzun, A.; Gates, B. C. Dynamic structural changes in a molecular zeolite-supported iridium catalyst for ethene hydrogenation. J. Am. Chem. Soc. 2009, 131, 15887-15894.

(14) Parr, R.G.; Yang, W.,Density-functional theory of atoms and molecules. Oxford University Press, New York, Oxford: 1989.

(15) Perdew, J. P.; Burke, K.; Ernzerhof, M. Generalized Gradient Approximation Made Simple. Phys. Rev. Lett. 1996, 77, 3865-3868.

(16) Hay, P. J.; Wadt, W. R. Ab initio effective core potentials for molecular calculations. Potentials for K to Au including the outermost core orbitals. J. Chem. Phys. 1985, 82, 299.

(17) Mattsson, A. E.; Armiento, R.; Schultz, P. A.; Mattsson, T. R. Nonequivalence of the generalized gradient approximations PBE and PW91. Physical Review B 2006, 73, 195123.

(18) Frisch, M.J.; Trucks, G.W.; Schlegel, H. B.; Scuseria, G.E.; Robb, M.A.; Cheeseman, J.R.; Scalmani, G.; Barone, V.; Petersson, G.A.; Nakatsuji, H.; Li, X.; Caricato, M.; Marenich, A.; Bloino, J.; Janesko, B.G.; Gomperts, R.; Mennucci, B.; Hratchian, H.P.; Ortiz, J. V.; Izmaylov, A. F.; Sonnenberg, J. L.; Williams-Young, D.; Ding, F.; Lipparini, F.; Egidi, F.; Goings, J.; Peng, B.; Petrone, A.; Henderson, T.; Ranasinghe, D.; Zakrzewski, V. G.; Gao, J.; Rega, N.; Zheng, G.; Liang, W.; Hada, M.; Ehara, M.; Toyota, K.; Fukuda, R.; Hasegawa, J.; Ishida, M.; Nakajima, T.; Honda, Y.; Kitao, O.; Nakai, H.; Vreven, T.; Throssell, K.; Montgomery Jr., J. A.; Peralta, J. E.; Ogliaro, F.; Bearpark, M.; Heyd, J. J.; Brothers, E.; Kudin, K. N.; Staroverov, V. N.; Keith, T.; Kobayashi, R.; Normand, J.; Raghavachari, K.; Rendell, A.; Burant, J. C.; lyengar, S. S.; Tomasi, J.; Cossi, M.; Millam, J. M.; Klene, M.; Adamo, C.; Cammi, R.; Ochterski, J. W.; Martin, R. L.; Morokuma,K.; Farkas, O.; Foresman, J. B.; Fox, D. J. Gaussian 09, Revision E. 01; Gaussian, Inc., Wallingford CT, 2009. 
(19) Wiberg, K. B.; Rablen, P. R. Atomic Charges. J. Org. Chem. 2018, 83, 15463-15469.

(20) Shaikhutdinov, S.; Heemeier, M.; Bäumer, M.; Lear, T.; Lennon, D.; Oldman, R. J.; Jackson, S. D.; Freund, H. J. Structure-Reactivity Relationships on Supported Metal Model Catalysts: Adsorption and Reaction of Ethene and Hydrogen on $\mathrm{Pd} / \mathrm{Al}_{2} \mathrm{O}_{3} / \mathrm{NiAl}(110)$. J. Catal. 2001, 200, 330-339.

(21) Vummaleti, S. V. C.; Genest, A.; Kuriakose, N.; Rösch, N. Ethene Dimerization and Hydrogenation over a Zeolite-Supported Rh(I)-Carbonyl Complex: Mechanistic Insights from DFT Modeling. ACS Catal. 2018, 8, 9836-9846.

(22) Biswas, S.; Pramanik, A.; Sarkar, P. Computational studies on the reactivity of alkyl halides over $\left(\mathrm{Al}_{2} \mathrm{O}_{3}\right)_{\mathrm{n}}$ nanoclusters: an approach towards room temperature dehydrohalogenation. Nanoscale 2016, 8, 10205-10218.

(23) Hoffman, A. S.; Debefve, L. M.; Zhang, S.; Perez-Aguilar, J. E.; Conley, E. T.; Justl, K. R.; Arslan, I.; Dixon, D. A.; Gates, B. C. Beating Heterogeneity of Single-Site Catalysts: MgOSupported Iridium Complexes. ACS Catalysis 2018, 3489-3498.

(24) Precomputed vibrational scaling factors. 2019, Retrievew from https://cccbdb.nist.gov/vibscalejust.asp

(25) Uzun, A.; Ortalan, V.; Browning, N. D.; Gates, B. C. A site-isolated mononuclear iridium complex catalyst supported on $\mathrm{MgO}$ : Characterization by spectroscopy and aberrationcorrected scanning transmission electron microscopy. J. Catal. 2010, 269, 318-328.

(26) Uzun, A.; Ortalan, V.; Browning, N. D.; Gates, B. C. Site-isolated iridium complexes on $\mathrm{MgO}$ powder: Individual Ir atoms imaged by scanning transmission electron microscopy. Chem. Commun. 2009, 4657-4659.

(27) Bhirud, V. A.; Ehresmann, J. O.; Kletnieks, P. W.; Haw, J. F.; Gates, B. C. Rhodium Complex with Ethylene Ligands Supported on Highly Dehydroxylated MgO: Synthesis, Characterization, and Reactivity. Langmuir 2006, 22, 490-496.

(28) Li, F.; Gates, B. C. Synthesis and Structural Characterization of Iridium Clusters Formed Inside and Outside the Pores of Zeolite NaY. J. Phys. Chem. B 2003, 107, 11589-11596.

(29) Babucci, M.; Fang, C.-Y.; Perez-Aguilar, J. E.; Hoffman, A. S.; Boubnov, A.; Guan, E.; Bare, S. R.; Gates, B. C.; Uzun, A. Controlling catalytic activity and selectivity for partial hydrogenation by tuning the environment around active sites in iridium complexes bonded to supports. Chem. Sci. 2019, 10, 2623-2632.

(30) Babucci, M.; Fang, C.-Y.; Hoffman, A. S.; Bare, S. R.; Gates, B. C.; Uzun, A. Tuning the Selectivity of Single-Site Supported Metal Catalysts with lonic Liquids. ACS Catal. 2017, 7, 6969-6972.

(31) Lu, J.; Serna, P.; Aydin, C.; Browning, N. D.; Gates, B. C. Supported molecular iridium catalysts: Resolving effects of metal nuclearity and supports as ligands. J. Am. Chem. Soc. 2011, 133, 16186-16195.

(32) Babucci, M.; Uzun, A. Effects of interionic interactions in 1,3-dialkylimidazolium ionic liquids on the electronic structure of metal sites in solid catalysts with ionic liquid layer (SCILL). J. Mol. Liq. 2016, 216, 293-297.

(33) Munoz, M.; Argoul, P.; Farges, F. Continuous Cauchy wavelet transform analyses of EXAFS spectra: A qualitative approach. Am. Mineral. 2003, 88, 694-700.

(34) Benfield, R. E. Mean coordination numbers and the non-metal-metal transition in clusters. J. Chem. Soc., Faraday Trans. 1992, 88, 1107-1110.

(35) Lin, Y.; Finke, R. G. Novel Polyoxoanion- and $\mathrm{Bu}_{4} \mathrm{~N}^{+}-$Stabilized, Isolable, and Redissolvable, 20-30- $\AA$. Ir $r_{\sim 300-900}$ Nanoclusters: The Kinetically Controlled Synthesis, Characterization, and Mechanism of Formation of Organic Solvent-Soluble, Reproducible Size, and Reproducible Catalytic Activity Metal Nanoclusters. J. Am. Chem. Soc. 1994, 116, 8335-8353.

(36) Aydin, C.; Lu, J.; Browning, N. D.; Gates, B. C. A "smart" catalyst: sinter-resistant supported iridium clusters visualized with electron microscopy. Angew. Chem. Int. Ed. 2012, 51, 5929-34.

(37) Babucci, M.; Hoffman, A. S.; Debefve, L. M.; Kurtoglu, S. F.; Bare, S. R.; Gates, B. C.; Uzun, A. Unraveling the Individual Influences of Supports and Ionic Liquid Coatings on the 
Catalytic Properties of Supported Iridium Complexes and Iridium Clusters. J. Catal. 2020, 387, 186-195.

(38) Blanksby, S. J.; Ellison, G. B. Bond Dissociation Energies of Organic Molecules. Acc. Chem. Res. 2003, 36, 255-263. 